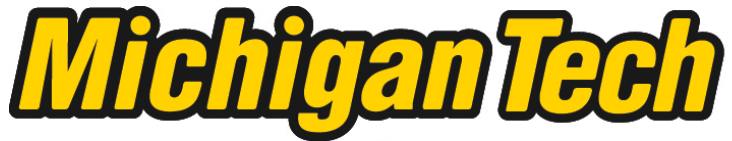 \\ Michigan Technological University Create the Future Digital Commons @ Michigan Tech
}

2015

\section{ASSESSMENT OF LAND COVER AND RIPARIAN ZONES FOR THE FORD RESEARCH FOREST - HICKEY CREEK/STURGEON RIVER AND FALLS RIVER SUBWATERSHEDS}

Fay Dearing

Michigan Technological University

Follow this and additional works at: https://digitalcommons.mtu.edu/etds

Part of the Landscape Architecture Commons, and the Remote Sensing Commons Copyright 2015 Fay Dearing

Recommended Citation

Dearing, Fay, "ASSESSMENT OF LAND COVER AND RIPARIAN ZONES FOR THE FORD RESEARCH FOREST - HICKEY CREEK/STURGEON RIVER AND FALLS RIVER SUBWATERSHEDS", Master's report, Michigan Technological University, 2015.

https://doi.org/10.37099/mtu.dc.etds/984

Follow this and additional works at: https://digitalcommons.mtu.edu/etds

Part of the Landscape Architecture Commons, and the Remote Sensing Commons 
ASSESSMENT OF LAND COVER AND RIPARIAN ZONES FOR THE FORD RESEARCH FOREST - HICKEY CREEK/STURGEON RIVER AND FALLS RIVER SUBWATERSHEDS

\title{
By
}

Fay Dearing

\begin{abstract}
A REPORT
Submitted in partial fulfillment of the requirements for the degree of MASTER OF SCIENCE

In Applied Ecology
\end{abstract}

MICHIGAN TECHNOLOGICAL UNIVERSITY

2015

(C) 2015 Fay Dearing 
This report has been approved in partial fulfillment of the requirements for the Degree of MASTER OF SCIENCE in Applied Ecology

School of Forest Resources and Environmental Science

Report Advisor: Dr. Ann L. Maclean

Committee Member: Dr. Veronica L. Webster

Committee Member: $\quad$ Dr. Christopher R. Webster

School Dean: $\quad$ Dr. Terry Sharik 


\section{TABLE OF CONTENTS}

LIST OF FIGURES

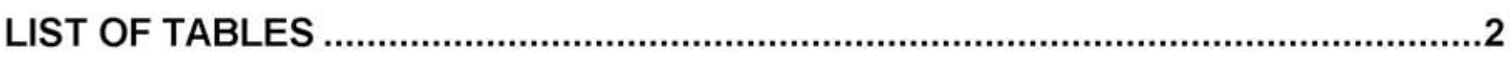

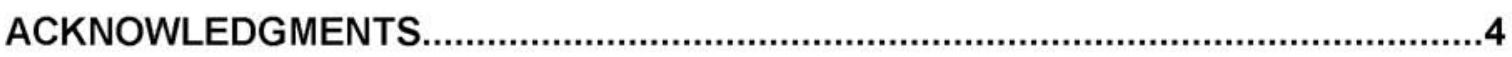

ABSTRACT

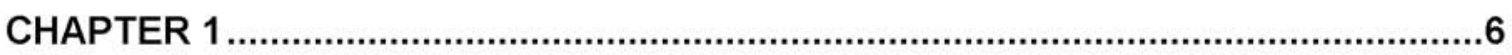

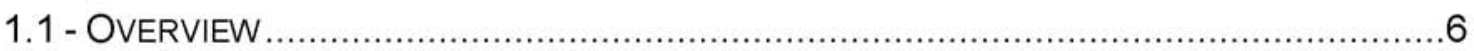

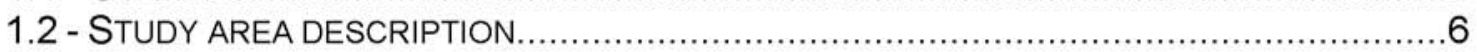

1.3 - GEOMORPHOLOGY AND EARLY EUROPEAN SETTLEMENT INFLUENCES.....................10

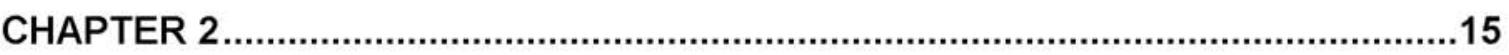

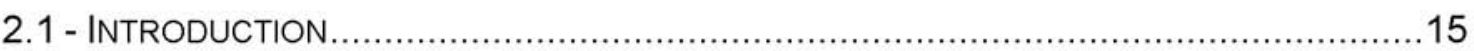

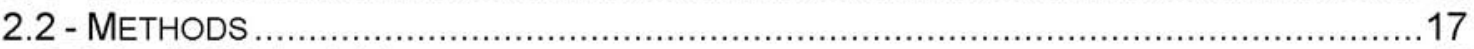

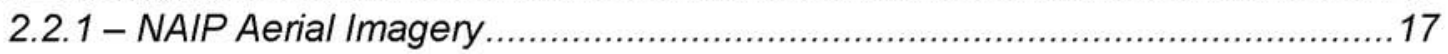

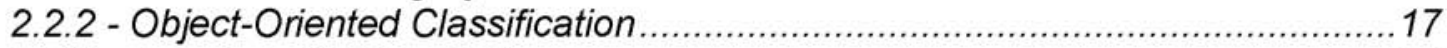

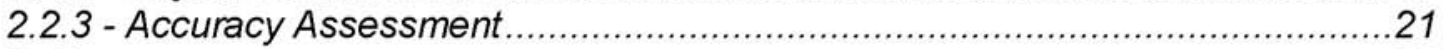

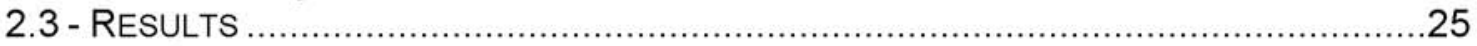

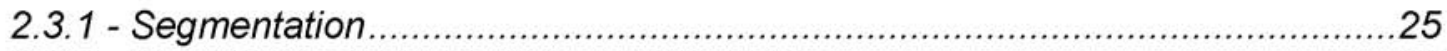

2.3.2 - Resulting Land Cover Map for Study Area …………................................26

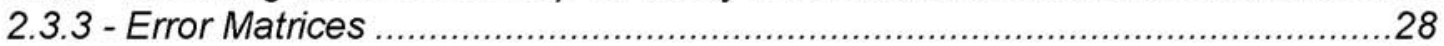

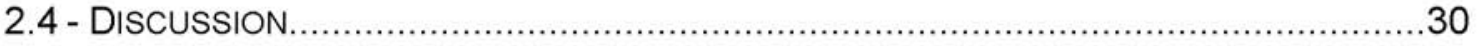

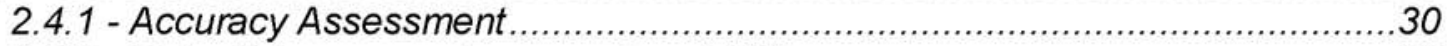

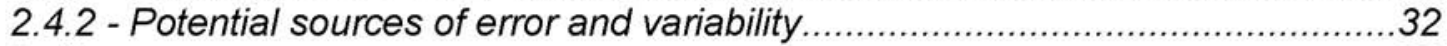

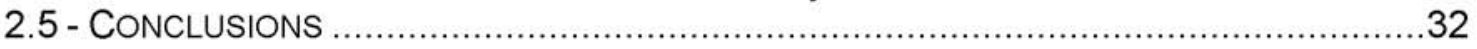

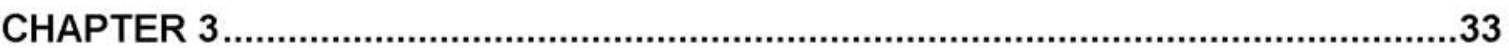

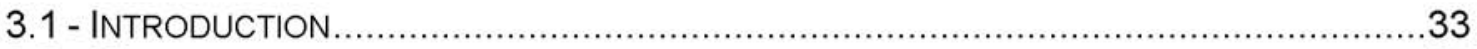

3.2 - METHODS

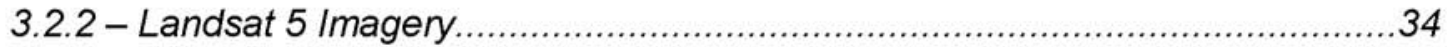

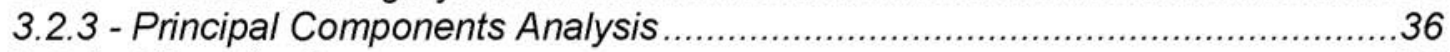

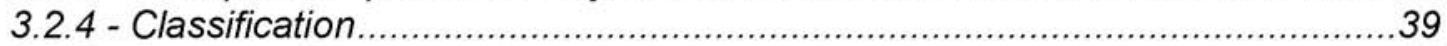

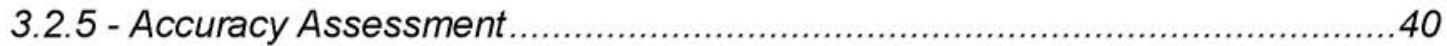

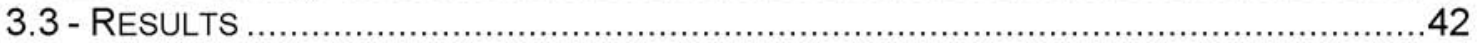

3.3.1 - Principal Components Analysis .........................................................42

3.3.2 - Resulting Land Cover Map for Study Area ..................................................5

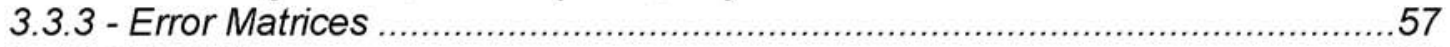

3.4 - DISCUSSION.

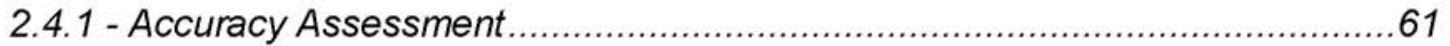

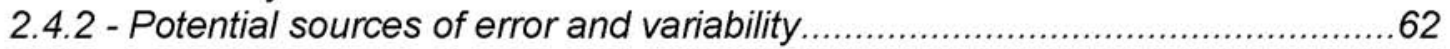

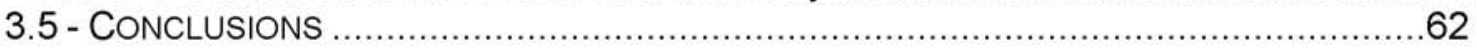

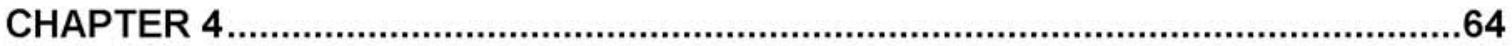

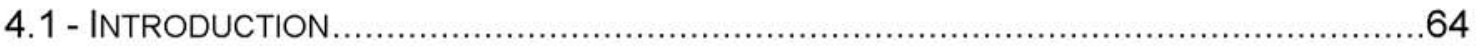

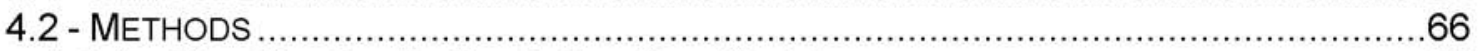

4.2.1 - The Riparian Buffer Delineation Model ..............................................66

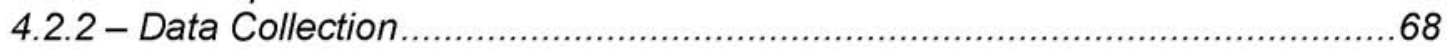

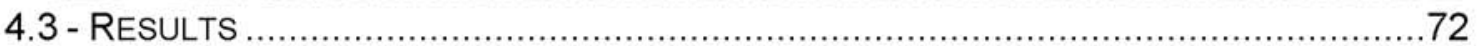




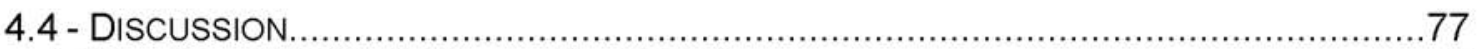

4.4.1 - Fixed Width Buffer vs. the RDBM .................................................... 77

4.4.2 - Potential sources of error and variability ........................................... 78

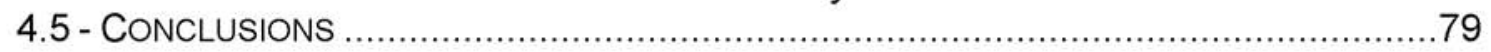

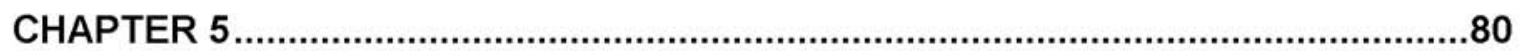

5.1 - APPLICATION OF THE RBDM ON THE FORD RESEARCH FOREST ...........................80

5.2 - SUGGESTIONS FOR FUTURE REMOTE SENSING ENDEAVORS ON THE FORD RESEARCH

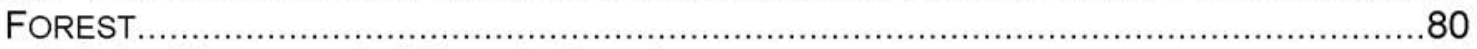

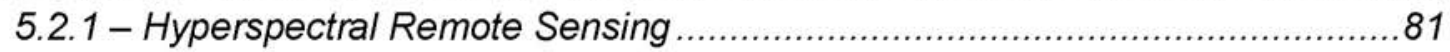

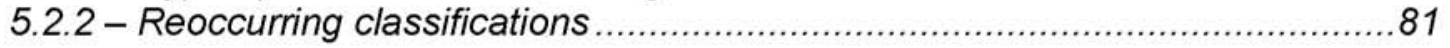

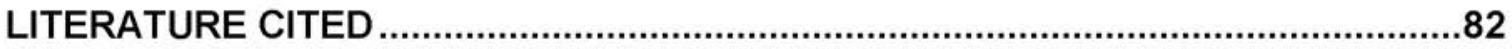

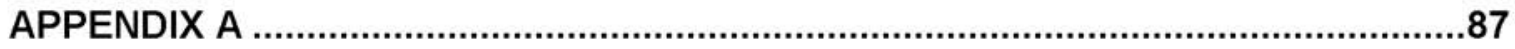

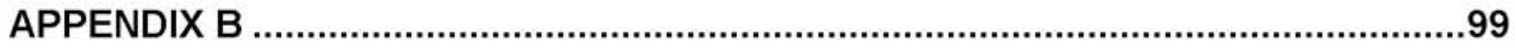




\section{LIST OF FIGURES}

Figure 1.1 - Study area for the Hickey Creek/Sturgeon River and Falls River watersheds

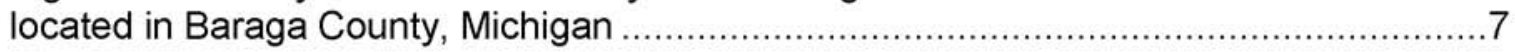

Figure 1.2 - Study map for NAIP imagery study area ...............................................

Figure 2.1 - True color mosaicked NAIP imagery of study area with Ford Research

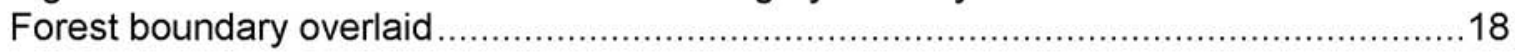

Figure 2.2 - Distribution of field accuracy points for the NAIP imagery..........................22

Figure 2.3 - Sample error matrix widely employed in assessing classified remotely

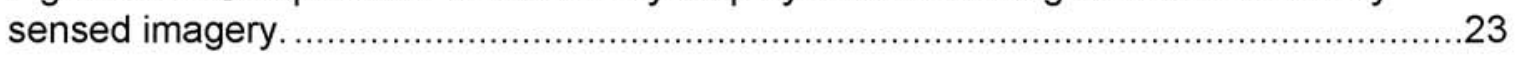

Figure 2.4 - Segmentation of NAIP imagery at Alberta, Michigan..............................26

Figure 2.5 - Final classification utilizing SPRING and NAIP mosaic ............................27

Figure 3.1 - Color infrared composites (Band 4, 3, 2 or near-IR, green, blue) Landsat TM

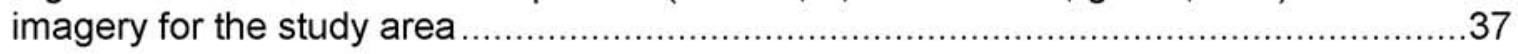

Figure 3.2 - Distribution of field accuracy points for the Landsat composite ..................41

Figure 3.3 - Examples of removed components due to noise errors. Component 22 of the combined seasonal composite representing popcorned imagery (left) and component 16 of the same composite depicting noise error (right) ...........................................46

Figure 3.4 - Maximum likelihood classification of Landsat composite............................58

Figure 3.5 - Enlargements of maximum likelihood classification of Landsat composite near Alberta, Michigan before the $3 \times 3$ majority filter was run (left) and after (right).......59

Figure 4.1 - Example of a riparian buffer zone utilizing Michigan best management practices (BMPs) taken from the Michigan DNR Sustainable soil and water quality

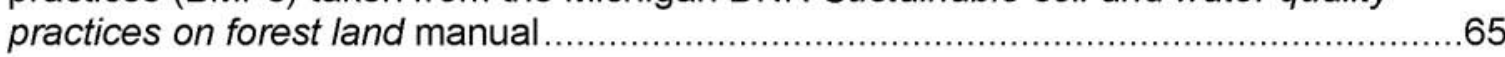

Figure 4.2 - The Sturgeon River, the largest river running through the study area ........69

Figure 4.3 - Riparian corridor species found on the Ford Research Forest lands. Jack in

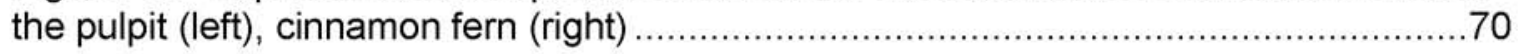

Figure 4.4 - Marsh marigold found on the Ford Research Forest................................70

Figure 4.5 - Upland species found on the Ford Research Forest. Yellow bead lily (left),

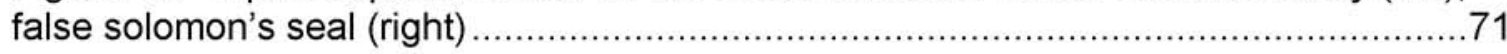

Figure 4.6 - Additional upland species found on the Ford Research Forest. Interrupted

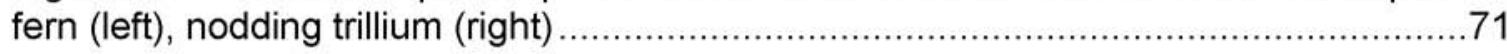

Figure 4.7 - RDBM, fixed width buffer, and field mapped riparian zone results for the Sturgeon River area

Figure 4.8 - RDBM, fixed width buffer, and field mapped riparian zone results for the Plumbago Creek and Ogemaw Creek area

Figure 4.9 - RDBM, fixed width buffer, and field mapped riparian zone results for an unnamed creek south of the Sturgeon River. 


\section{LIST OF TABLES}

Table 2.1 - Object-oriented information classes for the NAIP imagery .......................20

Table 2.2 - Object-oriented classification error matrix ...............................................28

Table 2.3 - Normalized object-oriented classification error matrix ...............................29

Table 2.4 - Overall statistics associated with the error matrix.......................................29

Table 2.5 - Producer and User accuracy statistics associated with the error matrix.......30

Table 3.1 - Spectral and spatial resolutions for Landsat 5 TM. ....................................35

Table 3.2 - Season, dates, ID numbers, and \% cloud cover of the selected TM

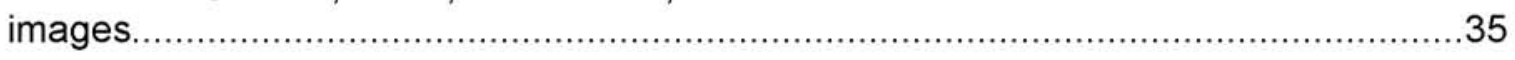

Table 3.3 - Classification scheme for the Landsat 5 mission imagery .........................40

Table 3.4 - Eigenvalues computed for the covariance matrix by ERDAS Imagine for the

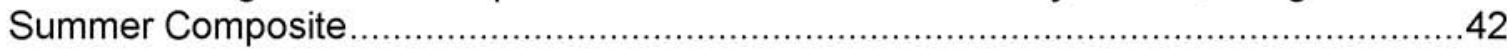

Table 3.5 - Eigenvalues computed for the covariance matrix by ERDAS Imagine for the

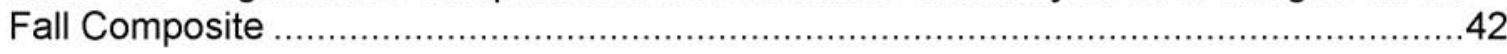

Table 3.6 - Eigenvalues computed for the covariance matrix by ERDAS Imagine for the

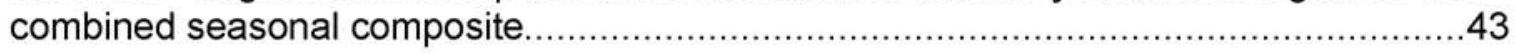

Table 3.7 - Total variance for each seasonal composite ..............................................43

Table 3.8 - Percentage of variance explained by each component for the Summer

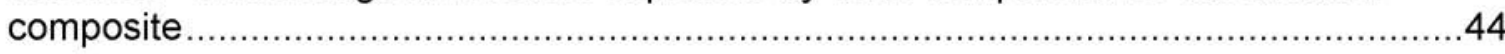

Table 3.9 - Percentage of variance explained by each component for the Fall composite.

Table 3.10 - Percentage of variance explained by each component for the combined

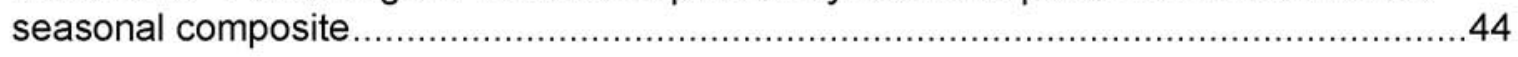

Table 3.11 - Eigenvectors for Summer composite generated by ERDAS Imagine ........47

Table 3.12 - Covariance matrix for Summer composite generated by ERDAS

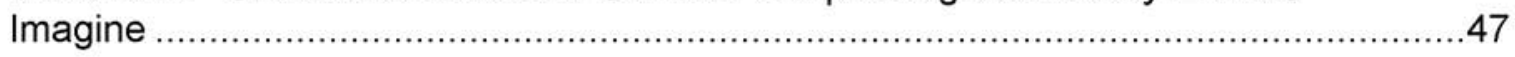

Table 3.13 - Eigenvectors for Fall composite generated by ERDAS Imagine ................48

Table 3.14 - Covariance matrix for Fall composite generated by ERDAS Imagine.........48

Table 3.15 - Eigenvectors for components 1 through 12 for the combined seasonal

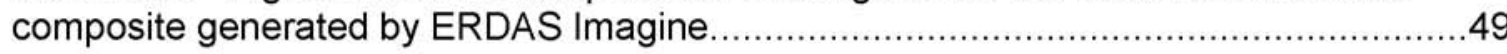

Table 3.16 - Eigenvectors for components 13 through 24 for the combined seasonal

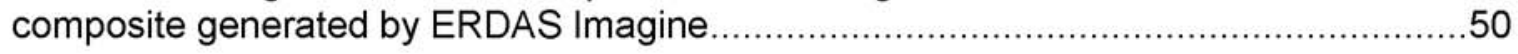

Table 3.17 - Covariance matrix for components 1 through 12 for the combined seasonal composite generated by ERDAS Imagine.

Table 3.18 - Covariance matrix for components 13 through 24 for the combined seasonal composite generated by ERDAS Imagine.

Table 3.19 - Factor loading matrix for Summer composite. Highlighted components are those that were removed from the composite 
Table 3.20 - Factor loading matrix for Fall composite. Highlighted components are those that were removed from the composite.

Table 3.21 - Factor loading matrix for combined seasonal composite for components 1 through12. Highlighted components are those that were removed from the composite.

Table 3.22 - Factor loading matrix for combined seasonal composite for components 13 through 24. Highlighted components are those that were removed from the composite.

Table 3.23 - Maximum likelihood classification error matrix

Table 3.24 - Normalized maximum likelihood classification error matrix 60

Table 3.25 - Overall statistics associated with the error matrix.

Table 3.26 - Producer's and user's accuracy statistics associated with the error matrix

Table 4.1 - Riparian Buffer Delineation Model data inputs and sources.

Table 4.2 - RDBM, fixed width buffer, and riparian zone results (in hectares) for the Ford Research Forest properties. 72 


\section{ACKNOWLEDGEMENTS}

I have so many people to thank I almost don't know where to start. To begin with, this report would never have happened without the guidance and knowledge of my advisor, Dr. Ann Maclean, whom I shall always be deeply grateful to. Thank you Ann. I would also like to thank the School of Forest Resources and Environmental Science, especially Dr. Terry Sharik and Dr. Andrew Storer. Not only has this school provided me with an excellent learning and research environment, they funded me too! I would also like to thank Mike Hyslop for being such a wonderful and knowledgeable teacher and for always having my back at IFP. Lastly I would like to thank my parents, Stephen and Janice, and my good friends Essie Ladkau, Justina Silva, and Moriah Nutt for being there as moral support through the years. I love you guys. 


\begin{abstract}
For landowners, knowing the contents of their land is always a primary concern. Traditional field based assessments can be challenging and expensive for large landholdings as well. However, by utilizing remote sensing and GIS models the land cover/land use and riparian areas can be more easily identified on a larger landscape level. To this end two remote sensing techniques were explored to create a land cover/land use map for the study area. The first, utilizing object-oriented techniques and high spatial resolution generated an overall accuracy of $71.97 \%$ which indicated a moderate agreement with the classified image and the field truthed ground data. The second method which utilized Landsat 5 TM multi-temporal imagery and more traditional classification techniques had an overall accuracy of $75.05 \%$. Lastly a GIS model for finding the delineated border of riparian areas was run to determine the extent of riparian zones on the Ford Research Forest. The results of this indicated that utilizing a flood height of 1 meter and incorporating hydric soil and wetland data into the model generated the most conservative model results.
\end{abstract}




\section{CHAPTER 1}

\section{A LOOK AT THE STUDY SITE}

\subsection{Overview}

The Michigan Technological University (MTU), School of Forest Resources and Environmental Science (SFRES) Ford Research Forest is the School's largest landholding. As these landholdings are the school's largest outdoor laboratory and a vital training ground for undergraduates and graduates, it is important to know and understand the area's land cover and riparian zones in order to better understand the ecosystem itself. As such, the following three objectives were undertaken to develop a better understanding of the forest and improve long term forest management plans:

I. Assess the utility of high spatial resolution (1 meter) NAIP aerial imagery for creating a detailed land use/cover map for the Ford Research Forest lands in the Hickey Creek/Sturgeon River and Falls River subwatersheds.

II. Assess the use of Landsat 5 Thematic Mapper (TM) multi-temporal imagery, and traditional pixel based classification techniques to develop a smaller scale land use/cover map for the same area as noted in objective 1

III. Assess the use of the Riparian Buffer Delineation Model (RBDM) and identify riparian zones through the Ford Research Forest in the same area.

\subsection{Study Area Description}

The study area was located in the northwestern Upper Peninsula (UP) of Michigan in Baraga County (Figure 1.1), and was comprised of two National Hydrography Dataset (NHD) HUC 11 subwatersheds encompassing approximately 27,561 hectares of mostly 


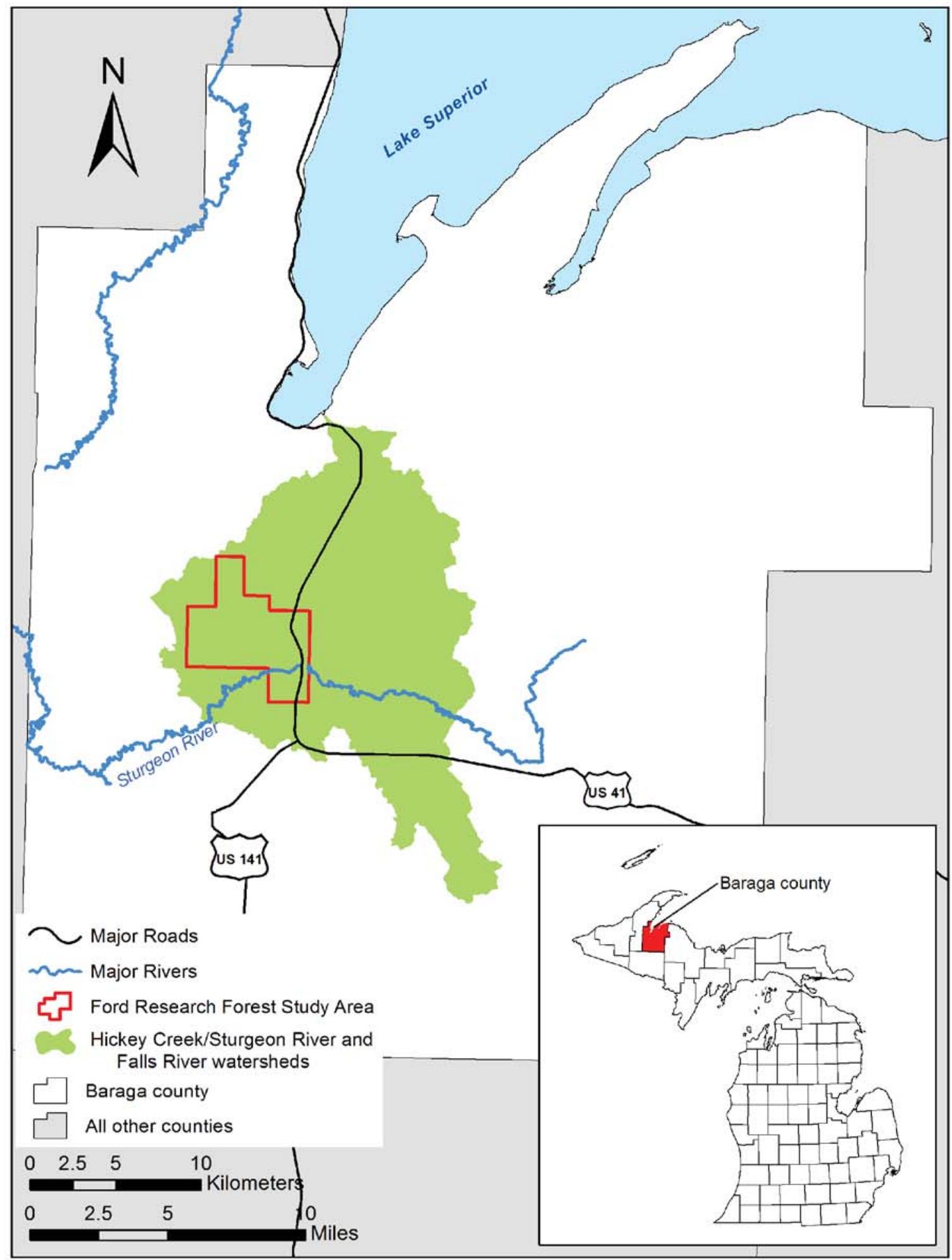

Figure 1.1 - Study area for Hickey Creek/Sturgeon River and Falls River watersheds located in Baraga County, Michigan. 
forested landscapes. The two subwatersheds were the Hickey Creek/Sturgeon River watershed (HUC code \# 40201050602) and the Falls River watershed (HUC code \# 40201040103). Subwatershed boundaries were downloaded from the USGS's National Map Viewer (URL: http://viewer.nationalmap.gov/viewer/).

This study area was chosen as the two subwatersheds contain the MTU Ford Center Research Forest. A 1,470 hectare series of parcels primarily composed of timber land and Alberta Village; a small historic community containing an early Ford Motor Company sawmill. Alberta was founded and constructed by Henry Ford beginning in 1935 and completed by 1938 . The sawmill in Alberta was used to provide Ford Motor Company with lumber needed to produce early model vehicles as well as present a positive idealized image to the public of a working company town. However, as wood in early model cars was replaced with other materials, the company no longer needed the forest lands and the sawmill, and donated the village and some 700 hectares of surrounding land to the Michigan College of Mining and Technology, now MTU. Additional land was gifted to the university from the Michigan Department of Conservation.

Topography for the area is comprised of rolling hills that vary between 180 to 550 meters above sea level. The climate of the area is characterized by warm summers and cold winters with the area receiving approximately 34 inches of rain each year and 148 inches of snow in the winter.

Major soil types include but are not limited to (Figure 1.2): Alstad, Carbondale, Champion, Kalkaska, Net, Peshekee, Rubicon, Sturgeon, and Tacoosh series soils (Soil Conservation Service, 1988).

There is a great variety of overstory tree species in the area, and common species include: jack pine (Pinus banksiana), white pine (Pinus strobus), red pine (Pinus 


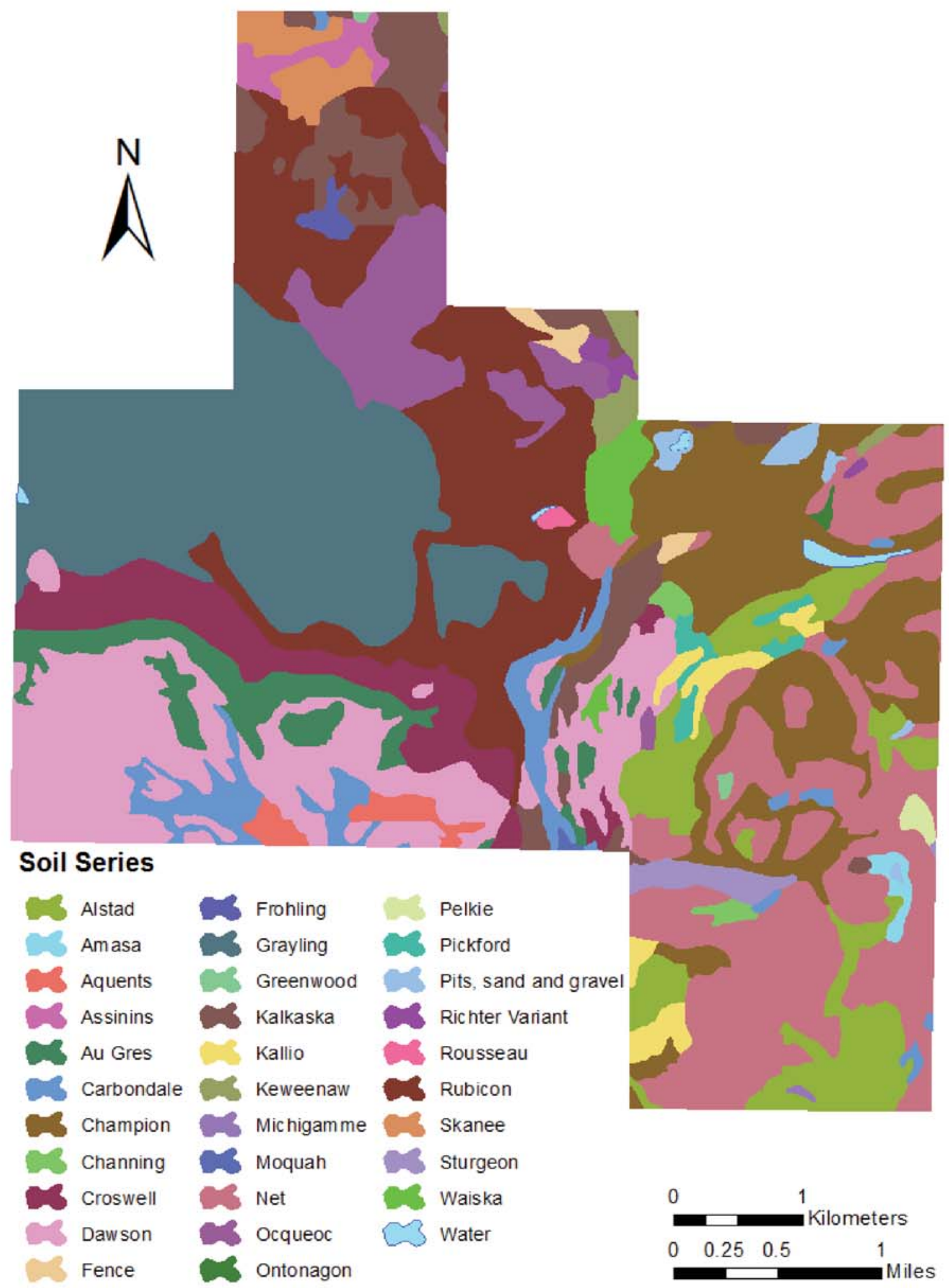

Figure 1.2 - Soil map for NAIP imagery study area. 
resinosa), Eastern hemlock (Tsuga Canadensis), balsam fir (Abies balsamea), black spruce (Picea mariana), tamarack (Larix laricina), northern white cedar (Thuja occidentalis), trembling aspen (Populus tremuloides), bigtooth aspen (Populus grandidentata), paper birch (Betula papyrifera), red maple (Acer rubrum), sugar maple (Acer saccharum), yellow birch (Betula alleghaniensis), American basswood (Tilia americana), white ash (Fraxinus americana), and red oak (Quercus rubra) among others (Barnes and Wagner, 1981). Due to the variety of forest cover types, this area was considered to be a representative sample of the various ecosystems located in the Western UP.

Common habitat types include: PVDc/PVCx (Pinus strobus/Vaccinium angustifolium - Deschampsia flexulosa or Carex spp.), PQE (Pinus strobe - Quercus rubra/Epigaea repens), PArV[w] (Pinus strobus/Vaccinium angustifolium [Wisconson variant]), PArVAa[w] (Pinus strobus/Vaccinium angustifolium - Aralia nudicaulis [Wisconson variant]), AVVb (Acer saccharum/ Vaccinium angustifolium - Viburnum acerfolium), TMC (Tsuga Canadensis/Maianthemum canadense - Coptis groenlandica), ATM (Acer saccharum - Tsuga Canadensis/Maianthemum canadense), ATD (Acer saccharum - Tsuga Canadensis/Dryopteris spinulosa), ATD-Hp (Acer saccharum Tsuga Canadensis/Dryopteris spinulosa - Hepatica variant), and AOCa (Acer saccharum/Osmorhiza claytoni - Caulophyllum thalictroides) among others (Burger and Kotar, 2003).

\subsection{Geomorphology and Early European Settlement Influences}

The UP is a variable landscape of differing landforms, streams, and soils overlain by a complex network of vegetation. This variation in landform and land cover is due to a long history of glaciation and human activities that have resulted in the current forest cover. 
While the Great Lakes region has been glaciated at least six times (Fullerton, 1986; Johnson, 1986), the advance and retreat of the last ice sheet had the greatest influence on current landforms (Larson and Schaetzl, 2001). This last glacial event, referred to as the Wisconsin glaciation, resulted in the Laurentide Ice Sheet expanding southward from northern and eastern Canada to cover the entire Great Lakes region. Johnson et al. (1997) describes how the this ice sheet advanced across the area starting $\sim 26,000$ years ago and reached its southernmost position in east-central Illinois by 20,000 to 19,000 years before present. Its borders then fluctuated over a period of $\sim 3,000$ years before beginning a retreat northward approximately 17,000 to 16,000 years before present. While the glacier was in its retraction phase, there were several additional advances made in $15,500,13,000,11,800$, and 10,000 years before present as well as the development of several glacial lakes. These glacial lakes included Lake Nipissing which covered much of the area now within Lake Superior's borders.

The glacial advance of 10,000 years ago in particular greatly affected the landscape of the UP as it created a prominent end moraine across much of the area and resulted in the creation of most of current landforms and soils (Larson and Schaetzl, 2001). By 9,000 years before present the glaciers retreated completely from the Great Lakes region (Karrow et al., 2000).

This extensive glaciation created a variety of landforms and resulting soils. Large areas of moraines, eskers, outwash plains, drumlins, etc. became the building blocks for the area's soils. Soil substrate is one of the primary reasons (along with disturbance history) behind the differentiation of habitat types and the vegetative communities growing on them (Ewing, 2002; Seymour et al., 2002; Stephenson, 1990; Whitney, 1986). Due to this great variation in soils and habitat types over 80 species of native trees and shrubs can be found in Michigan with exotic species introduced as well (Barnes and Wagner, 1981). 
The second greatest impact on the UP's vegetative diversity has been anthropogenic. While there is evidence that humans began to inhabit the southernmost portions of Michigan roughly 12,000 years ago (Anderson, 1991), very little seems to be known about these earliest inhabitants. More is known about the tribal groups collectively known as the Anishinaabe who moved into the area during the 1600 s (Clifton et al., 1986). However little has been written about the ecological impact they had on the forests of the Great Lakes region. Mann (2005) describes in his book, 1491: New revelations of the Americas before Columbus, much of the controversy about what the Americas were like before permanent European settlement. However, the fact remains that there is no consensus between researchers on the magnitude of ecological impact the Anishinaabe had on the UP or their population numbers. Instead, the primary focus of anthropogenic ecological research has been the impact European settlers had on changing the landscape of the area.

After the Government Land Office completed its surveys in the 1880 s, the UP was opened to settlement and exploitation. According to Dickmann and Leefers (2009) excellent book, The Forests of Michigan, the logging of Michigan's forests occurred in waves as companies looked for specific species. The first wave of logging activity harvested white pine (Pinus strobus) due to its pale coloration, ease of working, and light weight. These trees were considerably larger than many found on the current landscape; often 120 to 170 feet tall with a diameter at breast height $(\mathrm{DBH})$ of 3 to 5 feet or greater. At this time red pine (Pinus resinosa) was sometimes cut, but as logging operations increased and the plethora of large white pine decreased, loggers began to harvest different species and smaller diameters as well. The bark of hemlock (Tsuga canadensis) was collected due to its value to the tanning industry though the trees themselves were often left behind. Oaks (Quercus $s p$. ), maples (Acer $s p$.), and other 
hardwoods were also harvested, but at much reduced numbers when compared to pine, mostly due to the fact that it took early loggers additional effort to fell each tree.

As logging operations moved on, fire swept through the areas they left behind. Logging practices at the time left built up slash on the ground and massive forest fires burned through the region in the late 1800s. According to Dickmann and Leefers (2009), the regional fires ignited in October of 1871 after a summer of severe drought. The Great Chicago Fire was the first, destroying much of the early city and was immediately followed by the Peshtigo Fire which burned over 1.28 million acres near current day Green Bay, WI and north into Michigan's Menominee County. At the same time as the Peshtigo Fire was burning, the Great Michigan Fire was sweeping the Lower Peninsula (LP) of Michigan and ultimately burned over 2.5 million acres. More fires struck the LP in the late 1800 s, but according to Dickman and Leegers (2009), the UP had only minor forest fires until August 1896 when an out of control forest fire burned the Diamond Match Company timber yards and Ontonagon, MI, destroying over 228,000 acres. A separate forest fire burned L'Anse in the same year with more fires striking the UP through the early and mid-1900s. Some areas were so badly burned by fire and the soil structure destroyed that they've yet to recover and are still barren of anything but the hardiest of sedges.

This history of change makes the UP a complex and interesting landscape. Unlike other parts of the country where single species dominate thousands of acres of land, the UP is a variable ecosystem exceedingly dependent on glaciated landforms, the resulting soils and anthropogenic influences. While this makes the landscape more interesting, it also makes the area much more difficult to map and study as dramatic changes occur within short distances. For example, within the study area, cover types change from mesic deciduous forests dominated by sugar maple to the dry Baraga plains supporting jack pine in less than a mile. Other habitat changes occur within even 
shorter distances where small woody wetlands or mixed hemlock stands are found in tiny areas or on south facing slopes.

Utilizing advanced geospatial analysis tools, researchers are able to more easily study and understand this complex landscape. From computer models designed to assist land managers to protect riparian zones and water quality to aerial and satellite imagery used to classify modern day forest land cover, researchers can determine the best way to study the landscape in order to better protect it for the future while still utilizing its resources today. 


\section{CHAPTER 2}

\section{DELINEATION OF FOREST OVERSTORY SPECIES UTILIZING OBJECT-ORIENTED CLASSIFICATION IN THE HICKEY CREEKISTURGEON RIVER AND FALLS RIVER WATERSHEDS}

\subsection{Introduction}

Forest landowners and managers are concerned with land cover and its structure. Whether attempting to assess the forest's health, composition, and/or growth, land cover is important as it impacts land values and resource sustainability. Traditionally, land cover has been studied via field surveys, such as semi-regular timbercruises and fixed point plots, but with the improvement of aerial and satellite based imagery, remotely sensed data and its classification has become a more cost effective method of mapping land cover across large areas.

Object-oriented classification is a relatively new digital image processing technique best suited for high spatial resolution imagery. While the idea was proposed in the 1970 s, the technology was limited by computing power and did not become widely implemented until the 1990s (Platt and Rapoza, 2008). Object-oriented classification is unique when compared to more traditional pixel based classification techniques, as the imagery is first segmented into discrete image objects. An object is defined as an area where pixel values are relatively continuous in value or recorded reflectance (Benz et al., 2004). While object-oriented classification tends to be more commonly applied to imagery with a high spatial resolution (Leckie et al., 2003; Johansen et al., 2007; Mathieu et al., 2007) or even LiDAR (Antonarakis et al., 2008), there have been techniques developed that combine traditional pixel-based classifiers with objectoriented classification. 
Geneletti and Gorte (2003) attempted to combine the two techniques together. Utilizing Landsat Thematic Mapper (TM) 30 meter imagery and black and white orthophotos with 1 meter spatial resolution, they attempted to improve the land cover classification accuracy for a study area in northern Italy. The methods were quite unique as they classified the Landsat TM imagery with a traditional maximum likelihood technique; then separately segmented the orthophoto using a region-growing segmentation algorithm. The segmented orthophoto was then classified utilizing the completed Landsat land use/cover classification. The results of their study indicated that the orthophoto classification had a high level of accuracy.

In a paper by Johansen et al. (2007), QuickBird satellite imagery was used to identify riparian forested corridors in British Columbia. In addition to utilizing objectoriented analysis techniques, the researchers also undertook a texture analysis of the imagery to identify various vegetation structural classes. Ultimately the image's classification accuracy was improved by combining the two techniques. However, the imagery's overall accuracy was only improved by $5 \%$. This may indicate that while combining object-oriented classification with texture analysis can improve classifications for forested ecosystems, the additional work of completing a texture analysis may not be cost-effective.

Platt and Rapoza (2008) evaluated whether or not object-oriented analysis techniques improved classification accuracy. They utilized the program, Definiens eCognition ${ }^{\circledR}$ to classify an IKONOS 4 band satellite image with a 4 meter spatial resolution utilizing eight different combinations of pixel and object-oriented classification technique models. These models tested not only the differences between the objectoriented and pixel based analysis techniques, but also the classification algorithms (nearest-neighbor and maximum likelihood), whether expert knowledge was included, and whether or not feature space optimization was utilized. Ultimately, the model that 
utilized all of the object-oriented specific techniques had the highest classification accuracy. That said, the maximum likelihood algorithm typically associated with traditional pixel-based classifications did outperform the nearest-neighbor algorithm when evaluated as a standalone approach. However, as Definiens eCognition $®$ also utilizes expert knowledge, feature space optimization, and the segmentation of the image itself, the slight weakness in the nearest neighbor algorithm was overcome with the additional techniques. The objective of this project was to create and assess a land use/land cover map for the Ford Research Forest properties utilizing high spatial resolution imagery and an object-oriented classification technique.

\subsection{Methods}

\subsubsection{NAIP Aerial Imagery}

A high spatial resolution (1 meter) digital mosaicked orthophoto (Figure 2.1) was used to delineate land cover types for the study site. This image was a four-band National Agriculture Imagery Program (NAIP) orthophoto displaying three visible color bands (blue, green and red) as well as near-infrared reflectance acquired on July 21 , 2012. It was downloaded from The National Map Viewer (URL: http://viewer.nationalmap.gov/viewer/). The image was clipped to the Ford Research Forest boundary plus a $200-400$ meter buffer to match the extent of the Ford Research Forest LiDAR DEM.

\subsubsection{Object-Oriented Classification}

The segmentation and classification of the image was done in SPRING which is produced by the National Institute for Space Research based in São José dos Campos, Brasilia. This program was used because a study by Meinel and Neubert (2004) gave it an excellent review and high ranking when compared to other digital image processing 


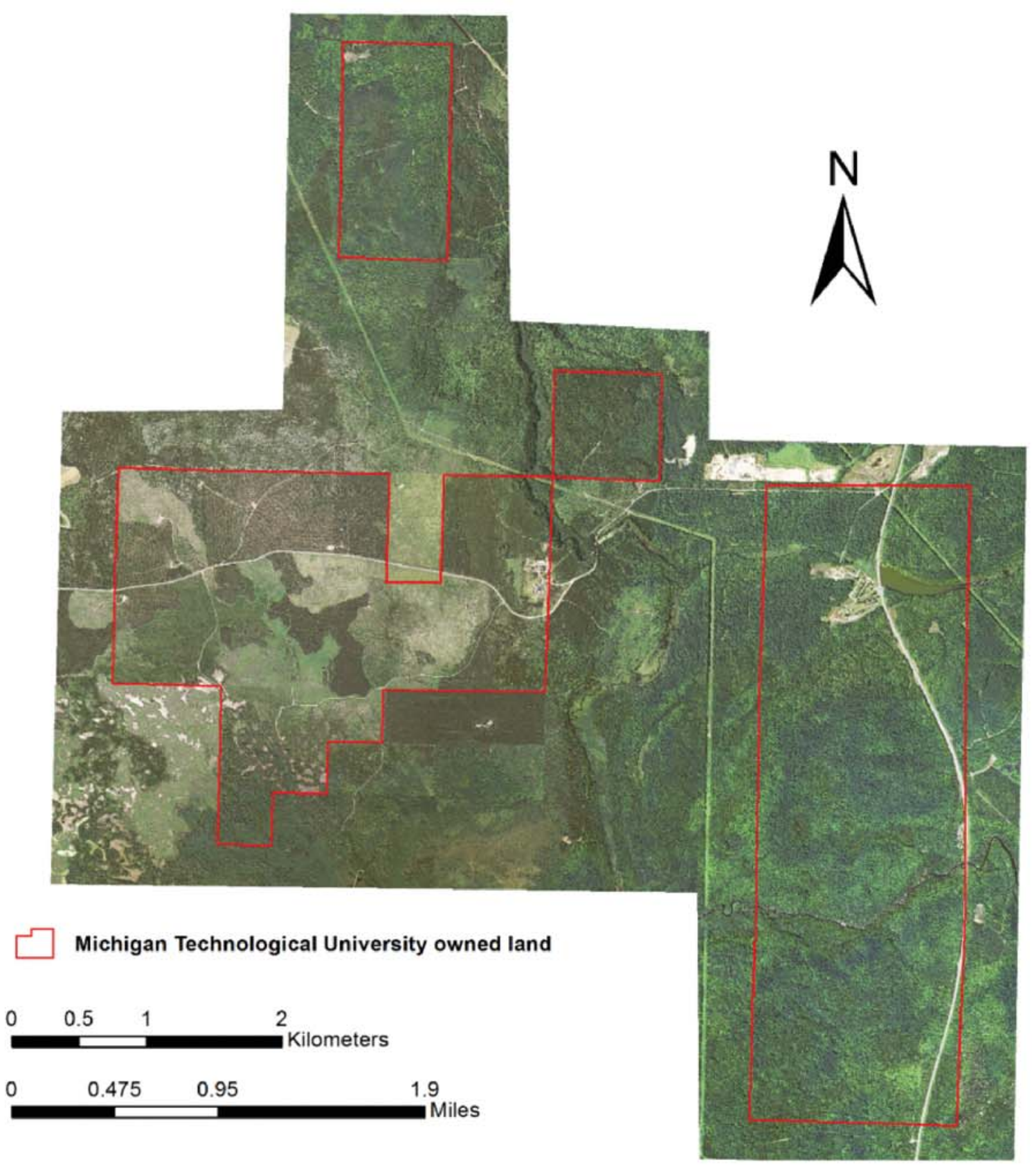

Figure 2.1 - True color mosaicked NAIP imagery of study area with Ford Research Forest boundary overlaid. 
programs. It is also readily available as a free download (URL: http://www.dpi.inpe.br/spring/english/). SPRING is a computationally intensive program and can be very unstable when processing large image files or when the image is segmented too finely. Hence a delicate balance must be met with the image segmented enough to meet the desired classification goals while not overwhelming the program's computational limitations causing it to crash.

The program's built in segmentation algorithms utilized the four bands of the NAIP imagery and the land cover classification scheme presented in Table 2.1 and a region growing method. This approach was chosen as it has been shown to provide better results than the program's basin detection method which is designed primarily for segmenting topographic imagery (Meinel and Neubert, 2004). The similarity parameter for the segmentation was set to 10 while the minimum area parameter was set to 1000 pixels. These parameters were chosen based on multiple runs to determine the best segmentation results. Once the segmentation of the image was completed, SPRING was also used to classify the image. 
Table 2.1 - Object-oriented information classes for the NAIP imagery.

\begin{tabular}{|c|c|}
\hline Classification Category & Description of class \\
\hline Aspen & $>75 \%$ trembling and/or bigtooth aspen, also paper birch \\
\hline Conifer & $\begin{array}{l}>75 \% \text { conifers with a canopy of red pine and/or white } \\
\text { pine }\end{array}$ \\
\hline Deciduous & $\begin{array}{l}>75 \% \text { deciduous species including sugar maple, red } \\
\text { maple, red oak, American bassword, yellow birch, and/or } \\
\text { white ash }\end{array}$ \\
\hline Jack Pine & $>75 \%$ jack pine \\
\hline Mixed & $\begin{array}{l}\text { A } 40-60 \% \text { mix of the conifer and deciduous class, } \\
\text { commonly including hemlock }\end{array}$ \\
\hline Open & $>75 \%$ grasslands and agricultural areas \\
\hline Paved & $\begin{array}{l}>75 \% \text { impermeable surfaces, gravel roads and/or bare } \\
\text { earth including gravel pits and buildings }\end{array}$ \\
\hline Tamarack & $>75 \%$ tamarack \\
\hline Water & $>75 \%$ water \\
\hline Woody Wetland & $\begin{array}{l}>75 \% \text { wet, forested wetlands including areas with } \\
\text { canopies of tag alder, balsam fir, black spruce, and/or } \\
\text { northern white cedar }\end{array}$ \\
\hline
\end{tabular}

Training sets were input into the program based on field data. Image classification was done utilizing the Bhattacharya distance (Bhat) for the feature selection and followed by a nearest-neighbor classifier with a 95\% acceptance threshold. The Bhattacharya distance algorithm (Equation 1) was chosen as it is capable of determining the spectral reflectance separability of two or more given classes, assuming that they have a Gaussian distribution and the means and covariance matrix can be calculated (Jensen 2005). As the NAIP imagery meets these requirements, the Bhattacharya distance algorithm was chosen. The Bhattacharya distance equation is (Duda et al., 2001):

$$
\text { Bhat }_{c d}=\frac{1}{8}\left(M_{c}-M_{d}\right)^{T}\left(\frac{V_{c}+V_{d}}{2}\right)^{-1}\left(M_{c}-M_{d}\right)+\frac{1}{2} \log _{\theta}\left[\frac{\left|\frac{V_{c}+V_{d}}{2}\right|}{\sqrt{\left(\left|V_{c}\right| *\left|V_{d}\right|\right)}}\right]
$$

Where $M_{c}$ and $M_{D}$ equal the means of classes $c$ and $d$ and

$V_{c}$ and $V_{D}$ equal the movariance matrices of classes $c$ and $d$ 


\subsubsection{Accuracy Assessment}

Guidelines developed by Congalton and Green (2008) were used to collect field ground truth data. These guidelines recommend having a minimum of 50 samples per class in study areas less than 1 million acres and containing fewer than 12 classes. Following these guidelines, 50 non-overlapping random points were generated for each of the 10 classes present in Table 2.1. Plot locations were randomly generated via ArcMap based on a stratified random sampling design. Due to some points being located on posted private land or otherwise inaccessible, 29 points were eliminated and a total of 471 ground truth points were collected. The distribution of the accuracy points is displayed in Figure 2.2 with the coordinates, classification, and field checked results in Appendix A.

Accuracy points were loaded onto a GPS unit and visited to determine their field results. Due to the small spatial resolution, assessment was simple. After arriving at the designated point location the user identified landcover type by class and recorded the results. Utilizing this ground truth data, an error matrix was created. Error matrixes are an easy, effective way to display image classification accuracy as they show errors of commission and omission for each information class or land cover type. A commission error is defined by Congalton and Green (2008) as "including an area in a category (or information class) when it does not belong to that category" while an omission error is defined as "excluding that area from the category in which it truly does belong." A sample error matrix, based on one found in Congalton and Green (2008) is shown in Figure 2.3. 


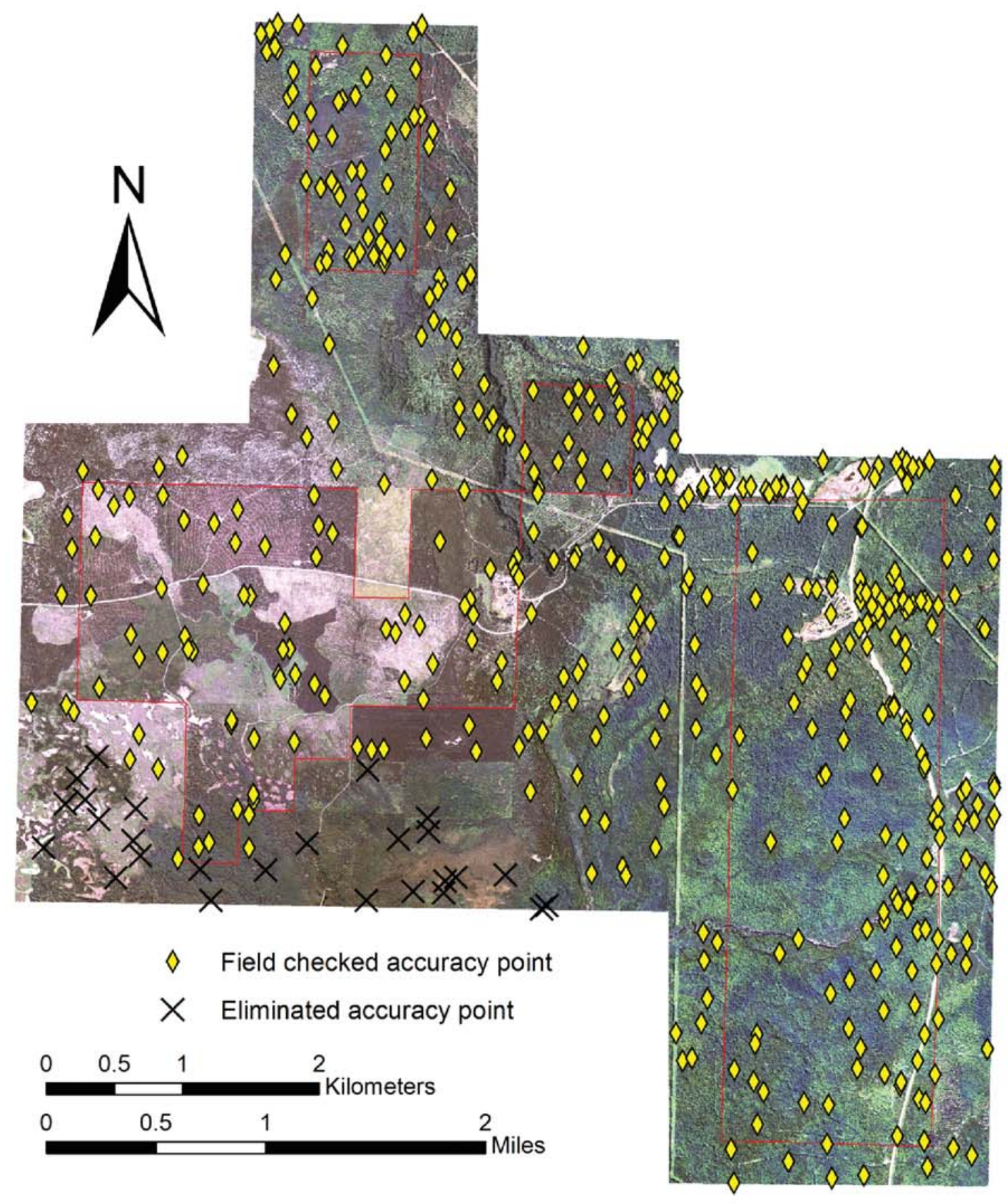

Figure 2.2 - Distribution of field accuracy points for the NAIP imagery. 


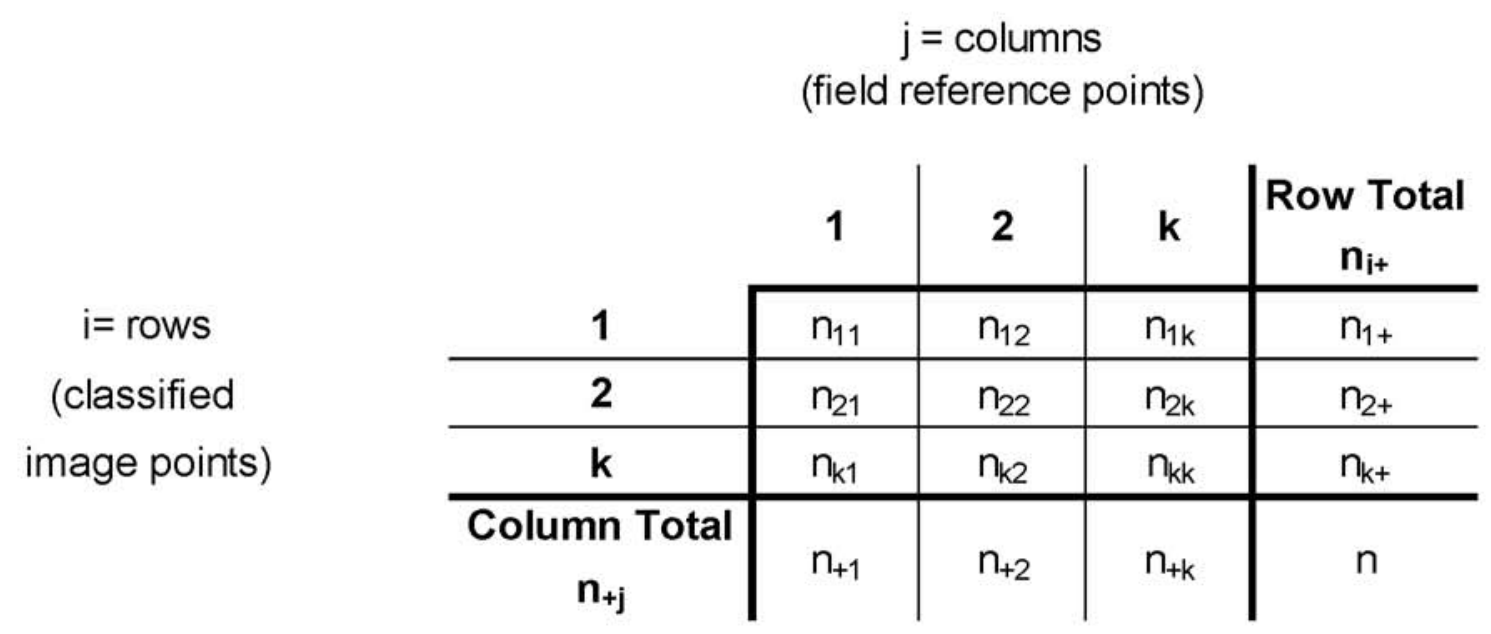

Figure 2.3 - Sample error matrix widely employed in assessing classified remotely sensed imagery.

Besides illustrating commission and omission errors, the error matrix also can be used to generate overall accuracy and kappa analysis results as well as producer's accuracy and user's accuracy for each information class. According to Congalton and Green (2008), the overall accuracy of an image is calculated by summing the major diagonal of the error matrix, which are the correctly classified sample points, then dividing the value by the total number of sample points collected (Equation 2).

$$
\text { Overall Accuracy }=\frac{1}{n} \sum_{i=1}^{k} n_{i i}
$$

Unlike the overall accuracy which rates the accuracy of the entire image, the producer's and user's accuracy are broken down by information class and determine the accuracy of each. The producer's accuracy calculates the probability that an information class for an area on the ground is classified correctly while the user's accuracy calculates the probability that a pixel labeled as a certain class is actually part of that class. The producer's accuracy is calculated by dividing the number of correctly 
classified sample points in a single class by the total column number of sample points for that class (Equation 3). Refer to Figure 2.2 for variable definition.

$$
\text { Producer's Accuracy }_{j}=\frac{n_{j j}}{n_{+j}}
$$

The equation for user's accuracy (Equation 4) is very similar to the producer's accuracy. However, instead of dividing by the information class's column total, the number of correctly classified sample points in a class is divided by the row total for each class (Congalton and Green, 2008). Refer to Figure 2.2 for variable definition.

$$
\text { User's Accuracy }_{i}=\frac{n_{i i}}{n_{i+}}
$$

The error matrix can also be used to calculate secondary classification statistics such as the Kappa analysis (KHAT or $\widehat{K}$ ) (Equation 5). Congalton and Green (2008) define Kappa analysis as the "measure of agreement [that] is based on the difference between the actual agreement in the error matrix (i.e., the agreement between the remotely sensed classification and the reference data as indicated by the major diagonal) and the chance of agreement which is indicated by the row and column totals (i.e., marginal)." The strength of the Kappa analysis is that if an image is being classified by multiple analysts or using multiple techniques, the variance and the z-statistic of the image can be calculated and compared to see which analyst or technique produces the most accurate results. While for the purposes of this study only one analyst using a single technique was used, reporting the $\widehat{K}$ value should still be done as it is considered to be a standard accuracy assessment measurement.

$$
\widehat{K}=\frac{n \sum_{i=1}^{k} n_{i i}-\sum_{i=1}^{k} n_{i+} n_{+i}}{n^{2}-\sum_{i=1}^{k} n_{i+} n_{+1}}
$$

A second analysis technique for analyzing the accuracy of remotely sensed data is Margfit analysis. Margfit analysis is "applied to normalize or standardize the error 
matrices for comparison purposes" and is a better representation than the overall accuracy assessment due to the fact that the error matrix is normalized. The Margfit analysis is a relatively simple procedure. First the error matrix is normalized by dividing the number of points for each cell of the matrix by the total number of points collected for each information class. This normalizes all of the error matrix cells and can be easily multiplied by 100 to generate a percentage for each cell. The resulting values are then averaged along the major diagonal axis to generate a single value.

The paper by Landis and Koch (1977) describes the possible values of $\widehat{K}$ by

dividing them into three groupings. Values with a $\widehat{K}$ greater than $80 \%$ represent a strong agreement between the classified image and the field collected reference data while values between $40 \%$ and $80 \%$ represent moderate agreement and values less than $40 \%$ represent poor agreement. For the purposes of this paper all of the accuracy assessments shall be judged by these groupings to determine if the classification is meaningful.

\subsection{Results}

\subsubsection{Segmentation}

Figure 2.4 depicts the final segmentation at Alberta. While requiring the minimum area to be at least 1,000 pixels (which equates to being 1,000 meters $^{2}$ ) the approach did tend to leave stand-alone trees grouped with larger objects. It also greatly simplified tree crown classification with entire tree crowns grouped together and somewhat reduced the impact of shadows. 


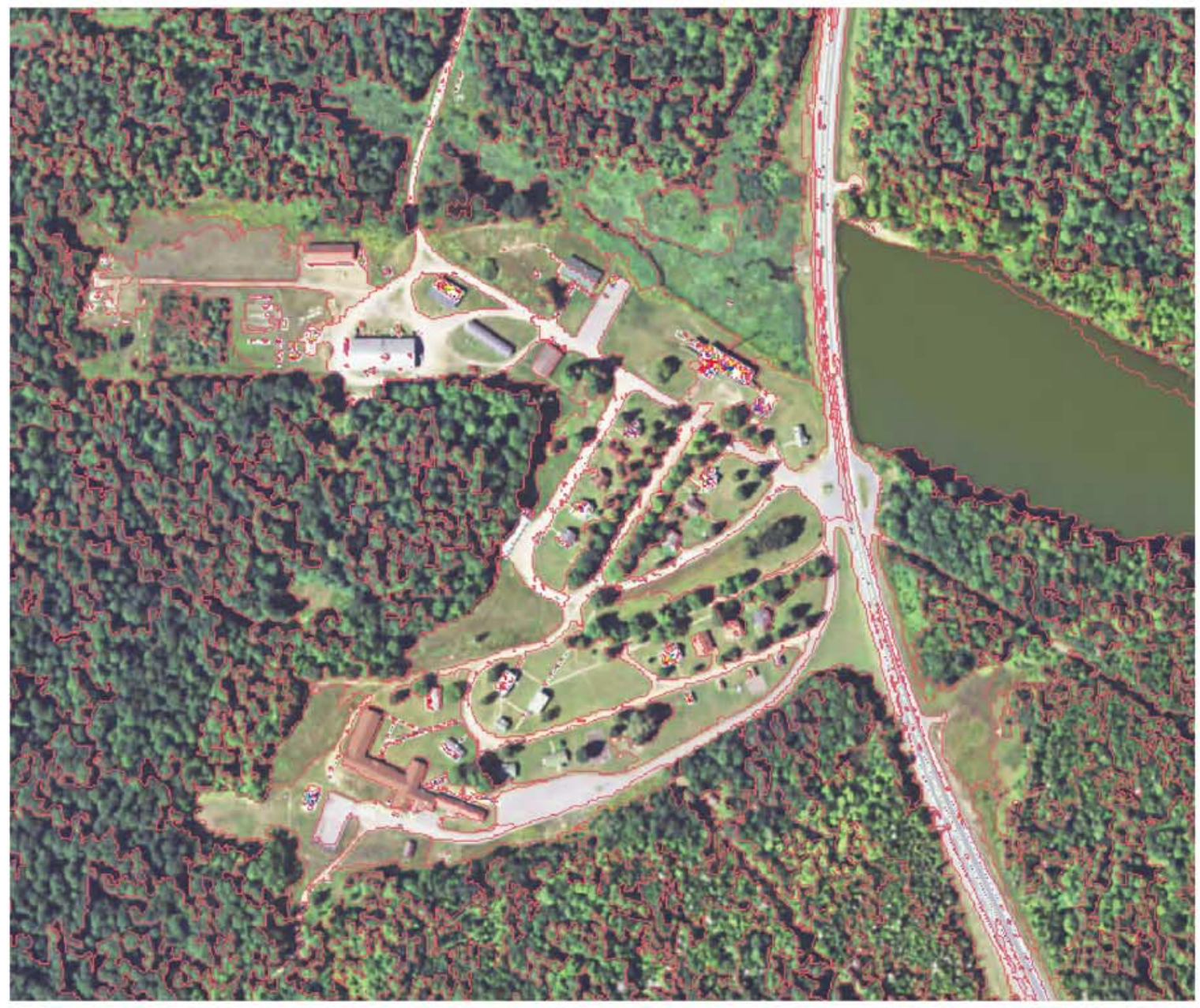

Figure 2.4 - Segmentation of NAIP imagery at Alberta, Michigan.

\subsubsection{Resulting Land Cover Map for Study Area}

Figure 2.5 shows the final land cover classification completed with SPRING. After completion, the image was exported out of SPRING as an .img (image) file in order that it could be imported into other programs for further analyses. 


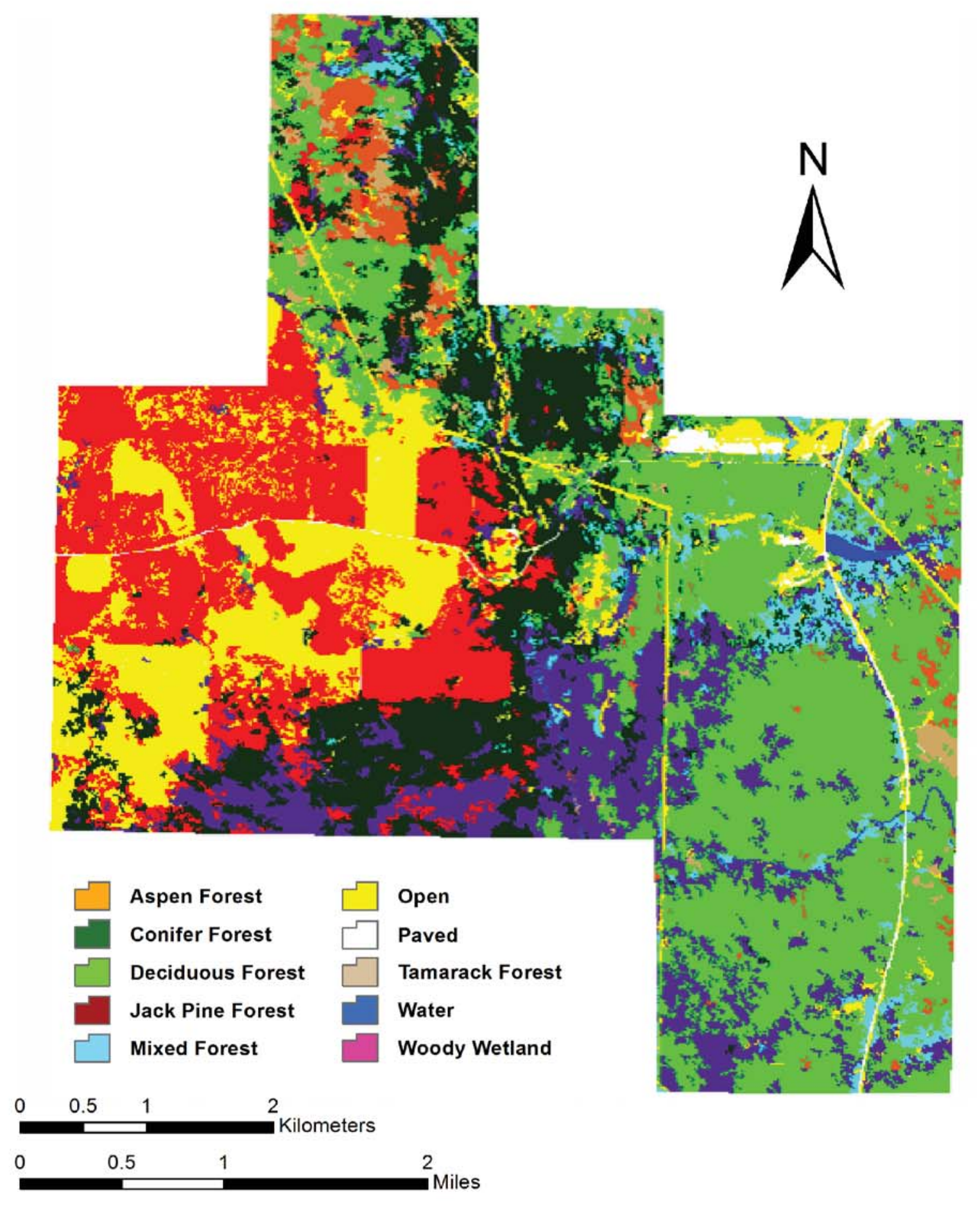

Figure 2.5 - Final classification utilizing SPRING and NAIP mosaic. 


\subsubsection{Error Matrices}

Table 2.2 displays the error matrix, depicting the breakdown of ground truth points versus the classification by information class. The major diagonal axis is highlighted in yellow for ease of reading as this axis represents how many ground truth points were correctly classified by information class.

\section{Table 2.2 - Object-oriented classification error matrix}

\begin{tabular}{|c|c|c|c|c|c|c|c|c|c|c|c|}
\hline & & & & & and Tru & Field & & & & & \\
\hline & Aspen & Conifer & Deciduous & Jack Pine & Mixed & Open & Paved & Tamarack & Water & $\begin{array}{c}\text { Woody } \\
\text { Wetland }\end{array}$ & Sum Row \\
\hline Aspen & 40 & 3 & 2 & - & - & - & - & 21 & - & - & 66 \\
\hline Conifer & 1 & 26 & 2 & 1 & . & - & - & - & 3 & 1 & 34 \\
\hline$>$ Deciduous & 9 & - & 42 & - & 5 & - & - & 4 & 1 & 10 & 71 \\
\hline Jack Pine & - & 3 & - & 42 & - & 2 & - & - & - & 2 & 49 \\
\hline Mixed & - & 1 & 2 & - & 34 & - & - & 7 & 3 & 7 & 54 \\
\hline Open & - & 1 & - & 1 & 2 & 38 & 2 & - & 6 & - & 50 \\
\hline Paved & - & - & - & - & - & 2 & 48 & - & 1 & - & 51 \\
\hline Tamarack & - & - & - & - & - & - & - & 11 & - & - & 11 \\
\hline Water & - & - & - & - & - & - & - & - & 36 & - & 36 \\
\hline $\begin{array}{l}\text { Woody } \\
\text { Wetland }\end{array}$ & - & 7 & 2 & 3 & 9 & 2 & - & 4 & - & 22 & 49 \\
\hline Sum Colum & 50 & 41 & 50 & 47 & 50 & 44 & 50 & 47 & 50 & 42 & 471 \\
\hline
\end{tabular}

The normalized error matrix used to calculate the Margfit analysis is depicted in Table 2.3 in percentages. The highlighted values represent the proportional percentage of points that were correctly classified in each information class. Overall the normalized values represent strong or moderate agreement with the exception of Tamarack which, at $23.04 \%$, represents poor agreement. 
Table 2.3 - Normalized object-oriented classification error matrix

\begin{tabular}{|c|c|c|c|c|c|c|c|c|c|c|c|}
\hline & \multicolumn{10}{|c|}{ Normalized Error Matrix } \\
\hline & & Aspen & Conifer & Deciduous & Jack Pine & Mxed & Open & Paved & Tamarack & Water & $\begin{array}{l}\text { Woody } \\
\text { Wetland }\end{array}$ \\
\hline \multirow{10}{*}{ 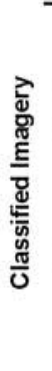 } & Aspen & $80.00 \%$ & $7.32 \%$ & $4.00 \%$ & - & - & - & - & $44.68 \%$ & - & - \\
\hline & Conifer & $2.00 \%$ & $63.41 \%$ & $4.00 \%$ & $2.13 \%$ & - & - & - & - & $6.00 \%$ & $2.38 \%$ \\
\hline & Deciduous & $18.00 \%$ & - & $84.00 \%$ & - & $10.00 \%$ & - & - & $8.51 \%$ & $2.00 \%$ & $23.81 \%$ \\
\hline & Jack Pine & - & $7.32 \%$ & - & $89.36 \%$ & - & $4.55 \%$ & - & - & - & $4.76 \%$ \\
\hline & Mixed & - & $2.44 \%$ & $4.00 \%$ & - & $68.00 \%$ & - & - & $14.89 \%$ & $6.00 \%$ & $16.67 \%$ \\
\hline & Open & - & $2.44 \%$ & - & $2.13 \%$ & $4.00 \%$ & $86.36 \%$ & $4.00 \%$ & - & $12.00 \%$ & - \\
\hline & Paved & - & - & - & - & - & $4.55 \%$ & $96.00 \%$ & - & $2.00 \%$ & - \\
\hline & Tamarack & - & - & - & - & - & - & - & $23.40 \%$ & - & - \\
\hline & Water & - & - & - & - & - & - & - & - & $72.00 \%$ & - \\
\hline & $\begin{array}{l}\text { Woody } \\
\text { Wetland }\end{array}$ & - & $17.07 \%$ & $4.00 \%$ & $6.38 \%$ & $18.00 \%$ & $4.55 \%$ & - & $8.51 \%$ & - & $52.38 \%$ \\
\hline
\end{tabular}

The final classification represents a moderate agreement with the ground truth data with an overall accuracy of $71.97 \%$; though the results of the Kappa analysis and the Margfit analysis were both slightly lower at $68.83 \%$ and $71.49 \%$ respectfully (Table 2.4). However these results were well within the margins of Landis and Koch (1997) grouping for moderate agreement and while not high, are considered acceptable classification percentages.

Table 2.4 - Overall statistics associated with the error matrix

\begin{tabular}{cc}
\hline Assesment Method & Result \\
\hline Overall Accuracy & $71.97 \%$ \\
Kappa Analysis & $68.83 \%$ \\
Margfit analysis & $71.49 \%$ \\
\hline
\end{tabular}

Table 2.5 depicts the producer's and user's accuracy broken down by information class. Overall, each information class exhibits strong or moderate agreement except for Tamarack which only has a producer's accuracy of $23.40 \%$. Another particularly low accuracy information class was the Woody Wetland class with a producer's accuracy of $52.38 \%$ and a user's accuracy of $44.90 \%$. While both of these values are still considered to represent moderate agreement, they are in the lower end of the value range. 
Table 2.5 - Producer and User accuracy statistics associated with the error matrix.

\begin{tabular}{ccc}
\hline Classification Category & Producer's Accuracy & User Accuracy \\
\hline Aspen & $80.00 \%$ & $60.61 \%$ \\
Conifer & $63.41 \%$ & $76.47 \%$ \\
Deciduous & $84.00 \%$ & $59.15 \%$ \\
Jack Pine & $89.36 \%$ & $85.71 \%$ \\
Mixed & $68.00 \%$ & $62.96 \%$ \\
Open & $86.36 \%$ & $76.00 \%$ \\
Paved & $96.00 \%$ & $94.12 \%$ \\
Tamarack & $23.40 \%$ & $100.00 \%$ \\
Water & $72.00 \%$ & $100.00 \%$ \\
Woody Wetland & $52.38 \%$ & $44.90 \%$ \\
\hline
\end{tabular}

\subsection{Discussion}

\subsubsection{Accuracy assessment}

Overall, the classification for the 10 information classes performed well. SPRING was adept at determining land cover types, doing an excellent job of differentiating between Paved, Open, and the various forested land cover types. However, it was found during field data collection that the Tamarack class was greatly over-estimated likely due to the lack of training sets available for this information class. Within the study area there is only one known larch (Larix $s p$.) plantation which covers approximately 13 hectares. While all training sets for this class were located within this area, there was considerable amount of land classified as being part of the Tamarack class, especially in Township 49N 34W, Section 02 of the Ford Research Forest. This part of the Ford Research Forest is admittedly a difficult area to classify as it seems to be in the process of undergoing a land cover type change. While there are many large conifers and jack pine on the landscape the area is largely being overtaken by aspen in the stem exclusion stage. However, it is possible that the combination of new aspen and older 
conifers and jack pine were spectrally similar enough to established larch to result in the misclassification.

Besides the Tamarack class, the other class that seemed unusually low was the Woody Wetland class with a producer's accuracy of $52.38 \%$ and a user's accuracy of 44.90\%. As seen in Table 2.3 there was considerable confusion between this class and the Deciduous, Conifer, and Mixed classes. While the precise reason for this confusion are unknown, it is likely due to the Woody Wetland class being a particularly broad class in terms of the range of spectral reflectance values which included deciduous wetland species such as tag alder and willow along with evergreen species such as black spruce, northern white cedar, and balsam fir. Dividing up this class into separate deciduous and coniferous woody wetland classes may correct this issue in future assessments.

Additionally, the Water class with a producer's accuracy of $72.00 \%$ was also lower than expected. Due to water's ability to absorb almost all near infrared electromagnetic radiation, clear and deep water typically is depicted on imagery as black and can be one of the easiest information classes to classify. However, field checking showed many of the erroneous water areas were located on edges where tree and open areas met or where there was a rapid change in tree heights due to past logging activity. These locations generated dark shadows which closely resembled the spectral signature of water. Creating a separate information class specifically for shadows could correct this issue. However, error assessment in particular could be made more difficult as shadows are not stationary objects and can easily move depending on season, time of day, and amount of cloud cover. 


\subsubsection{Potential sources of error and variability}

Although attempts were made to reduce bias and error across data collection and processing, there are still potential error sources that should be mentioned. Due to the accuracy assessment plots being randomly generated via stratified random sampling, there were 21 plots that were located on either private posted land or areas otherwise inaccessible for assessment purposes. As this land was largely grouped in the south-west portion of the image this area has been largely unexplored and it is uncertain how accurate the classification is for the area.

\subsection{Conclusions}

For high resolution spatial imagery, using an object-oriented classification program such as SPRING produces a high overall accuracy. While the addition of an information class specifically for shadows could further improve accuracy, determining the accuracy of a shadow class could be difficult. Additionally, while increasing the minimum pixel area to 1000 pixels (approximating an area of 1000 meters $^{2}$ on the ground) left stand-alone objects, such as trees, grouped in with larger feature objects it partially negated the effect of shadows on the classification as well as allowed the user to classify entire stands of trees as a single object which more closely approximates how we, as humans, perceive them. 


\section{CHAPTER 3}

\section{DELINEATING LAND USE/COVER FROM MULTI-TEMPORAL LANDSAT THEMATIC MAPPER (TM) DATA FOR HICKEY CREEKISTURGEON RIVER AND FALLS RIVER WATERSHEDS}

\subsection{Introduction}

Accurately classifying forest cover and habitat types for the Upper Great Lakes region using Landsat TM imagery is difficult and has been the topic of considerable research (Bryant et al.,1980; Nelson et al., 1984; Mickelson et al., 1998; Olthof et al., 2008). As many forest management plans require a forest cover type classification, it is important to accurately delineate and map these diverse landscapes. Additionally, land cover changes can also be identified and monitored more efficiently utilizing remotely sensed imagery.

Landsat is the longest, continuous satellite based image acquisition program in the world, with data collection beginning with Landsat 1 in July, 1972. The moderate temporal (16 days) and spatial ( $30 \mathrm{~m}$ for Landsat 5 missions) resolutions make it idea for monitoring forests both in the short term and from a historical perspective (USGS, 2014). However, despite the availability and acquisition characteristics of Landsat imagery, mapping the landscape at the individual tree species level can be a very difficult process due to spectral reflectance variation within species (Hill et al., 2010) and spectral reflectance similarity between species. Additionally spectral reflectance for a single pixel often includes shadows and understory reflectance combining with tree crown reflectance.

Hyperspectral imagery helps correct this issue via improved spectral resolution using many narrow width bands and improves forest cover type classification accuracy. However, high spatial resolution hyperspectral imagery is not widely available and is not 
always cost effective (Gaveau and Hill, 2003). Additionally, some hyperspectral classification techniques require researchers to collect and maintain a spectral library of all the materials and species they desire to classify which can be expensive and time consuming. Vegetation is particularly difficult to build a spectral library for due to its dynamic life cycle and the many environmental factors, such as drought, which influence this cycle and hence the spectral reflectance curves. To overcome these obstacles, image classification techniques have been developed using multi-temporal imagery composites to take advantage of the seasonal variability of reflectance and use it to advantage (Schriever and Congalton, 1995; Wolter et al., 1995; Mickelson et al., 1998; Key et al., 2001; Oetter et al., 2001; Hill et al., 2010). The key to using multi-temporal imagery composties is to select scenes that cover the spring leaf-out, summer growth, and autumn senescence to improve classification accuracy based on the known phenology of different tree species. Utilizing these data, it is possible to improve classification accuracy. Both Eder (1998) and Schriever and Congalton (1995) found that autumn imagery had the highest classification accuracy and should be incorporated into studies utilizing this method.

Keeping all this in mind, the objective of this project was to create a land cover/land use map utilizing Landsat 5 TM multi-temporal imagery and traditional pixel based classification techniques.

\subsection{Methods}

\subsubsection{Landsat 5 Imagery}

A total of four images were downloaded for this project. All images were acquired by the Landsat 5 TM sensor and were obtained from the USGS Earth Explorer website (URL: http://earthexplorer.usgs.gov/). TM imagery is composed of 7 spectral bands 
(Table 3.1) which includes a thermal band. The spatial resolution is 30 meters for the 6 reflective bands and 120 meters for the thermal band.

Table 3.1 - Spectral and spatial resolutions for Landsat 5 TM.

\begin{tabular}{cccc}
\hline Band & Type & Range & Pixel Size \\
\hline 1 & Visible & $0.45-0.52 \mu \mathrm{m}$ & 30 meters \\
2 & Visible & $0.52-0.60 \mu \mathrm{m}$ & 30 meters \\
3 & Visible & $0.63-0.69 \mu \mathrm{m}$ & 30 meters \\
4 & Near-IR & $0.76-0.90 \mu \mathrm{m}$ & 30 meters \\
5 & Mid-IR & $1.55-1.75 \mu \mathrm{m}$ & 30 meters \\
6 & Thermal & $10.40-12.50 \mu \mathrm{m}$ & 120 meters \\
7 & Mid-IR & $2.08-2.35 \mu \mathrm{m}$ & 30 meters \\
\hline
\end{tabular}

Two summer and two fall images were selected for the study site. No suitable spring imagery was available due to extensive cloud cover. Details for each image are presented in Table 3.2. While the percent cloud cover for the September 26, 2001 image is quite high at $40 \%$, cloud cover was absent for the study area except for a small portion near the town of L'Anse, and was included in the study.

Table 3.2 - Season, dates, ID numbers, and \% cloud cover of the selected TM images.

\begin{tabular}{cccc}
\hline Season & Date of Acquisition & Scene ID \# & \% Cloud Cover \\
\hline Summer & June 2, 2011 & LT50240282011153PAC01 & $0 \%$ \\
Summer & July 11, 2002 & LT50240282002192LGS01 & $0 \%$ \\
Fall & September 26, 2001 & LT50240282001269LGS01 & $40 \%$ \\
Fall & October 5, 2010 & LT50240282010278EDC00 & $0 \%$ \\
\hline
\end{tabular}

The images were downloaded and converted to an img format. Pixel values were transformed from geometrically and radiometrically corrected digital numbers (DN) to top-of-atmosphere reflectance using ERDAS Imagine. The approach developed by Chander et al. (2009) was utilized. Additionally, a simple histogram based dark-object 
correction was done for each image as there were several clear, deep lakes in the image to represent true dark bodies (Chavez, 1988). No further atmospheric correction was required due to the lack of cloud cover or haze in the images. A $500 \mathrm{~m}$ buffer was generated around each watershed utilizing ArcMap 10.2 with the resulting area becoming the study area boundary. The images were then clipped to the extended study area and are shown in Figure 3.1.

\subsubsection{Principal Components Analysis}

The images were combined into several composites: a summer composite made up of the 2 summer images, a fall composite made up of the 2 fall images, and an all season composite made up of all 4 images. A principal component analysis (PCA) of each composite was generated with the resultant components evaluated for redundant information and noise. Covariance and correlation were calculated utilizing methods detailed in Jensen (2004) and are presented below.

The process of completing a PCA takes several steps. The first generates eigenvalues to determine the percent of total variance explained by each component. From the eigenvalues the total variance can be calculated using a simple summation of the values (Equation 6).

$$
\text { Total Variance }=\sum_{p=1}^{n} \text { eigenvalue } \lambda_{p}
$$

Where eigenvalue $\lambda_{p}$ is the ERDAS Imagine generated

eigenvalue for component $p$ and $n$ is the total number of components 

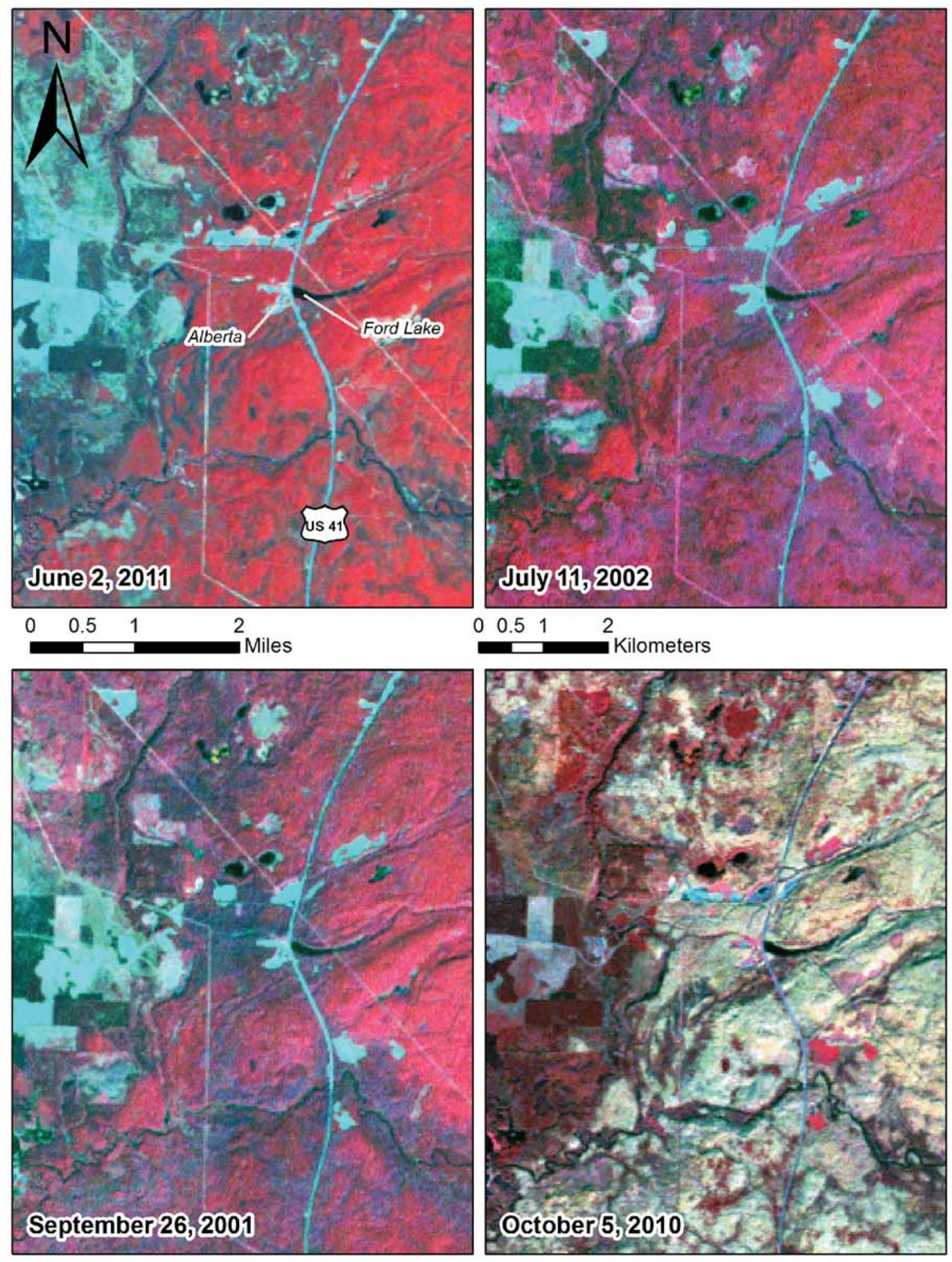

Figure 3.1 - Color infrared composites (Band 4, 3, 2 or near-IR, green, blue) Landsat TM imagery for the study area. 
The total variance for the components is calculated, and the percentage of variance explained by each component is determined (Equation 7):

$$
\text { Percentage of variance explained by component } p=\frac{\text { eigenvalue } \lambda_{p} * 100}{\text { Total Variance }}
$$

Next the eigenvectors and covariance matrix for the components are directly calculated by ERDAS Imagine. Next, the factor loading matrix was calculated. Factor loadings tell the user the contribution each band of imagery makes to each PCA component and is calculated using Equation 8 where the information contribution by $r$ each band $(\mathrm{k})$ to principal component $(\mathrm{p})$ is represented by $R_{k p}$ :

$$
\begin{aligned}
& \qquad R_{k p}=\frac{a_{k p} * \sqrt{\lambda_{p}}}{\sqrt{V a r_{k}}} \\
& a_{k p}=\text { eigenvalue for band } k \text { and component } p \\
& \lambda_{p}=\text { pth eigenvalue } \\
& \operatorname{Var}_{k}=\text { variance of band } k \text { from the covariance matrix }
\end{aligned}
$$

After the factor loadings were calculated, components were removed from the composites due to noise, scanner errors, or otherwise poor data contribution. Components that contained low factor loading values but did not contain considerable noise were kept as they did not otherwise slow down the final analysis. Additionally, while these factor loading values were minimal, it was hoped that the components would still contribute meaningful data to the analysis so they were kept. 


\subsubsection{Classification}

Once the number of components was reduced, ERDAS Imagine was used to classify the composites. A multiple classification technique was used. First the images were classified using unsupervised classification. A total of 75 spectral classes were identified utilizing the ISOdata classification algorithm with a 95\% convergence level. Utilizing field data the classes were identified by cover type using Imagine's Signature Editor. Spectral classes representing multiple information classes were eliminated during this process with the "purer" spectral classes that best represented the information classes retained. These spectral classes were then grouped together by information class or cover type. Once this process was completed the signatures were input into Imagine's supervised classification program for final processing. For the supervised classification the Maximum Likelihood parametric rule was used, utilizing all available signature statistics. The resulting 3 classifications (spring, fall, all) were overlaid to generate a composite multi date classification. A $3 \times 3$ majority filter used to smooth the image and reduce the salt and pepper appearance. Salt and pepper effect is an error seen in classification in which single pixels are misclassified resulting in greater classification inaccuracy. This is primarily an issue only in traditional pixel-based classifications (Weih and Riggan, 2010).

A total of ten information classes were developed for the classification of the Landsat composites (Table 3.3): Aspen, Conifer, Deciduous, Emergent Wetland, Jack Pine, Mixed, Open, Tamarack, Water, and Woody Wetland. 
Table 3.3 - Classification scheme for the Landsat 5 TM imagery.

\begin{tabular}{|c|c|}
\hline Classification Category & Description of class \\
\hline Aspen & $>75 \%$ trembling and/or bigtooth aspen, also paper birch \\
\hline Conifer & $\begin{array}{l}>75 \% \text { conifers with a canopy of red pine and/or white } \\
\text { pine }\end{array}$ \\
\hline Deciduous & $\begin{array}{l}>75 \% \text { deciduous species including sugar maple, red } \\
\text { maple, red oak, American bassword, yellow birch, and/or } \\
\text { white ash }\end{array}$ \\
\hline Emergent Wetland & $\begin{array}{l}>75 \% \text { wet, unforested wetlands including reeds, sedges, } \\
\text { shrubs, and willow }\end{array}$ \\
\hline Jack Pine & $>75 \%$ jack pine \\
\hline Mixed & $\begin{array}{l}\text { A } 40-60 \% \text { mix of the conifer and deciduous class, } \\
\text { commonly including hemlock }\end{array}$ \\
\hline Open & $\begin{array}{l}>75 \% \text { grasslands, agriculture, impermeable surfaces, } \\
\text { gravel roads and/or bare earth including gravel pits and } \\
\text { buildings }\end{array}$ \\
\hline Tamarack & $>75 \%$ tamarack \\
\hline Water & $>75 \%$ water \\
\hline Woody Wetland & $\begin{array}{l}>75 \% \text { wet, forested wetlands including areas with } \\
\text { canopies of tag alder, balsam fir, black spruce, and/or } \\
\text { northern white cedar }\end{array}$ \\
\hline
\end{tabular}

\subsubsection{Accuracy Assessment}

For the purposes of this project, the accuracy assessment for the Landsat TM pixel-based classification was analyzed using the same methods and equations detailed in Chapter 2, Section 2.2.4. A total of 50 field points were randomly generated for each information class for a total of 500 accuracy assessment points. A total of 473 accuracy assessment points were field checked with 27 points not visited due to private posted lands and/or physical inaccessibility. Figure 3.2 displays the distribution of the field accuracy points for the area of interest and the coordinates, classification, and field checked results in Appendix B. 


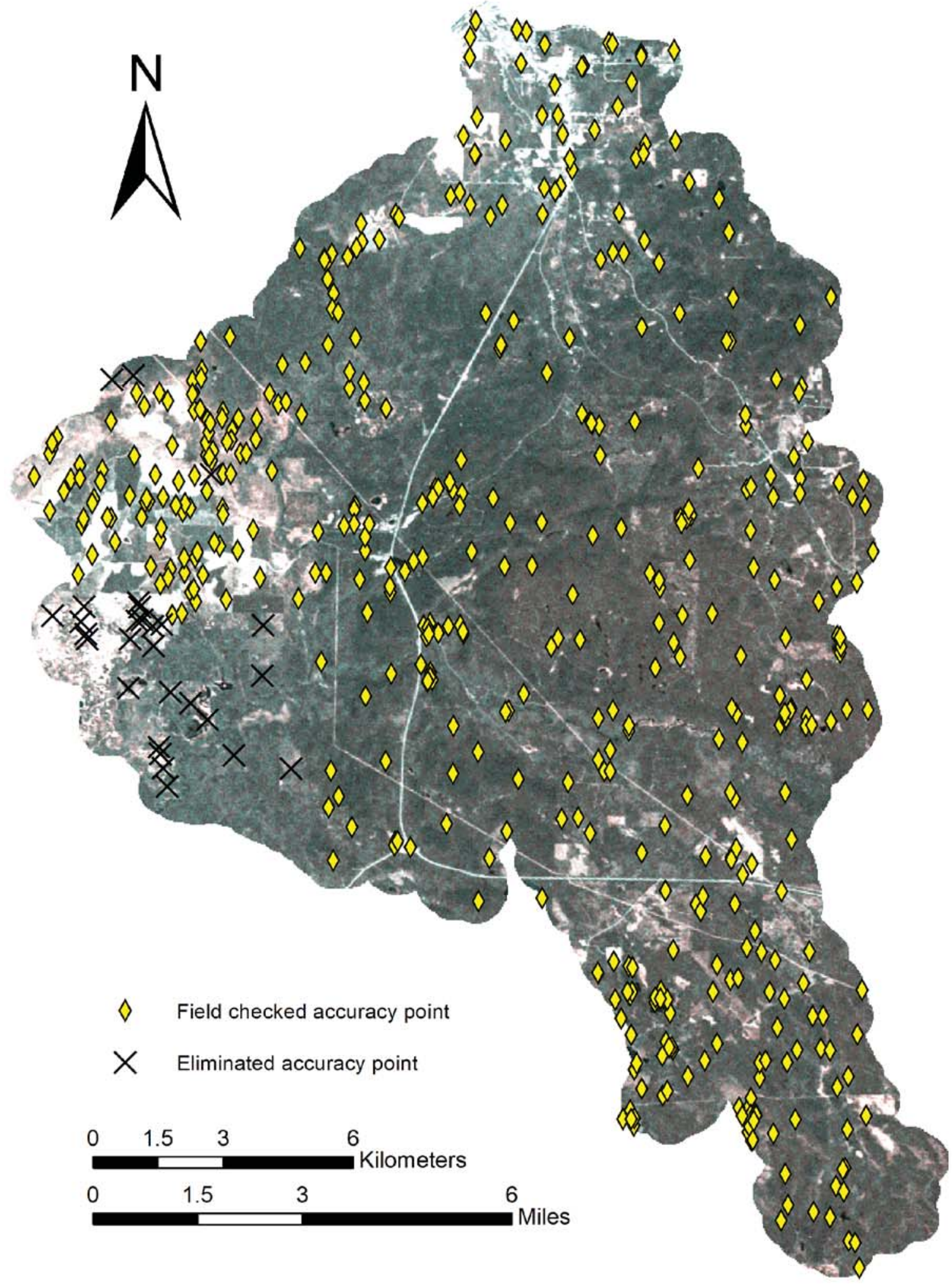

Figure 3.2 - Distribution of field accuracy points for the Landsat composite. 


\subsection{Results}

\subsubsection{Principal Components Analysis}

Tables 3.4, 3.5, and 3.6 display the eigenvalues calculated for each component by ERDAS Imagine and for each seasonal composite. These values were utilized to calculate their respective total variance which is displayed in Table 3.7.

Table 3.4 - Eigenvalues computed for the covariance matrix by ERDAS Imagine for the Summer Composite.

\begin{tabular}{cc|cc}
\hline Component & Eigenvalue & Component & Eigenvalue \\
\hline 1 & 418.529 & 7 & 0.990 \\
2 & 109.743 & 8 & 0.763 \\
3 & 49.301 & 9 & 0.377 \\
4 & 11.716 & 10 & 0.062 \\
5 & 2.862 & 11 & 0.048 \\
6 & 1.336 & 12 & 0.022 \\
\hline
\end{tabular}

Table 3.5 - Eigenvalues computed for the covariance matrix by ERDAS Imagine for the Fall Composite.

\begin{tabular}{cc|cc}
\hline Component & Eigenvalue & Component & Eigenvalue \\
\hline 1 & 189.308 & 7 & 1.127 \\
2 & 45.487 & 8 & 0.816 \\
3 & 31.261 & 9 & 0.678 \\
4 & 9.830 & 10 & 0.425 \\
5 & 3.043 & 11 & 0.094 \\
6 & 1.664 & 12 & 0.016 \\
\hline
\end{tabular}


Table 3.6 - Eigenvalues computed for the covariance matrix by ERDAS Imagine for the combined seasonal composite.

\begin{tabular}{cc|cc}
\hline Component & Eigenvalue & Component & Eigenvalue \\
\hline 1 & 581.133 & 13 & 1.126 \\
2 & 139.859 & 14 & 0.896 \\
3 & 69.436 & 15 & 0.711 \\
4 & 27.366 & 16 & 0.604 \\
5 & 18.993 & 17 & 0.511 \\
6 & 13.283 & 18 & 0.366 \\
7 & 9.534 & 19 & 0.247 \\
8 & 7.275 & 20 & 0.094 \\
9 & 3.590 & 21 & 0.061 \\
10 & 1.719 & 22 & 0.048 \\
11 & 1.570 & 23 & 0.027 \\
12 & 1.042 & 24 & 0.008 \\
\hline
\end{tabular}

Table 3.7 - Total variance for each seasonal composite.

\begin{tabular}{cc}
\hline & Total Variance \\
\hline Summer & 595.750 \\
Fall & 283.750 \\
Combined & 879.500 \\
\hline
\end{tabular}

Utilizing the above eigenvalues and the total variance for each composite, the percentage of variance explained by each component was calculated with their cumulative variance expressed in percent for each seasonal image. As Table 3.8 depicts, for the Summer composite over $99 \%$ of the cumulative variance was explained by the first five components, while it takes 7 components for the Fall composite (Table 3.9) and 10 components for the combined seasonal composite (Table 3.10). 
Table 3.8 - Percentage of variance explained by each component for the Summer composite.

\begin{tabular}{ccccccc}
\hline Component & $\mathbf{1}$ & $\mathbf{2}$ & $\mathbf{3}$ & $\mathbf{4}$ & $\mathbf{5}$ & $\mathbf{6}$ \\
\hline Percentage & 70.253 & 18.421 & 8.275 & 1.967 & 0.480 & 0.224 \\
Cumulative & 70.25 & 88.67 & 96.95 & 98.92 & 99.40 & 99.62 \\
\hline Component & $\mathbf{7}$ & $\mathbf{8}$ & $\mathbf{9}$ & $\mathbf{1 0}$ & $\mathbf{1 1}$ & $\mathbf{1 2}$ \\
\hline Percentage & 0.166 & 0.128 & 0.063 & 0.010 & 0.008 & 0.004 \\
Cumulative & 99.79 & 99.91 & 99.98 & 99.99 & 100.00 & 100.00 \\
\hline
\end{tabular}

Table 3.9 - Percentage of variance explained by each component for the Fall composite.

\begin{tabular}{ccccccc}
\hline Component & $\mathbf{1}$ & $\mathbf{2}$ & $\mathbf{3}$ & $\mathbf{4}$ & $\mathbf{5}$ & $\mathbf{6}$ \\
\hline Percentage & 66.716 & 16.031 & 11.017 & 3.464 & 1.073 & 0.586 \\
Cumulative & 66.72 & 82.75 & 93.76 & 97.23 & 98.30 & 98.89 \\
\hline \hline Component & 7 & 8 & 9 & 10 & 11 & 12 \\
\hline Percentage & 0.397 & 0.288 & 0.239 & 0.150 & 0.033 & 0.006 \\
Cumulative & 99.28 & 99.57 & 99.81 & 99.96 & 99.99 & 100.00 \\
\hline
\end{tabular}

Table 3.10 - Percentage of variance explained by each component for the combined seasonal composite.

\begin{tabular}{ccccccc}
\hline Component & $\mathbf{1}$ & $\mathbf{2}$ & $\mathbf{3}$ & $\mathbf{4}$ & $\mathbf{5}$ & $\mathbf{6}$ \\
\hline $\begin{array}{l}\text { Percentage } \\
\text { Cumulative }\end{array}$ & 66.0754382 & 15.9021525 & 7.89498015 & 3.11156558 & 2.15955229 & 1.51026008 \\
\hline \hline Component & 7 & 8 & 9 & 10 & 11 & 12 \\
\hline Percentage & 1.08403592 & 0.82719912 & 0.40814408 & 0.1954457 & 0.17851792 & 0.11846237 \\
Cumulative & 97.7379847 & 98.5651838 & 98.9733279 & 99.1687736 & 99.3472915 & 99.4657539 \\
\hline \hline Component & 13 & 14 & 15 & 16 & 17 & 18 \\
\hline Percentage & 0.12806194 & 0.10185247 & 0.08081273 & 0.06866893 & 0.0581319 & 0.04162123 \\
Cumulative & 99.5938158 & 99.6956683 & 99.776481 & 99.8451499 & 99.9032819 & 99.9449031 \\
\hline \hline Component & 19 & 20 & 21 & 22 & 23 & 24 \\
\hline Percentage & 0.02808048 & 0.01065888 & 0.00691274 & 0.00544005 & 0.00305566 & 0.00094913 \\
Cumulative & 99.9729836 & 99.9836424 & 99.9905552 & 99.9959952 & 99.9990509 & 100 \\
\hline
\end{tabular}


The eigenvectors (Table 3.11) and the covariance matrix (Table 3.12) were both generated and exported by ERDAS Imagine for the Summer composite. This process was repeated for the Fall eigenvectors (Table 3.13) and Fall covariance matrix (3.14) as well as combined seasons eigenvectors (Table 3.15 \& Table 3.16) and covariance matrix (Table $3.17 \&$ Table 3.18). For ease of reading all of these tables have been included at the end of the section.

All of the above data was used to generate the factor loadings going into the degree of correlation for the Summer (Table 3.19), Fall (Table 3.20) and combined seasons (Table $3.21 \&$ Table 3.22). Again, for ease of reading these tables have been included at the end of the section. The shaded values depict the components that were ultimately removed from the stacked composite for various reasons. As the number of bands was not overwhelmingly computational intensive, components were primarily removed due to noise. Image noise was considered to be due to issues such as visible scanner paths and/or lines, sensor noise, or otherwise redundant information found in another component. Figure 3.3 depicts examples of these image noise errors. 


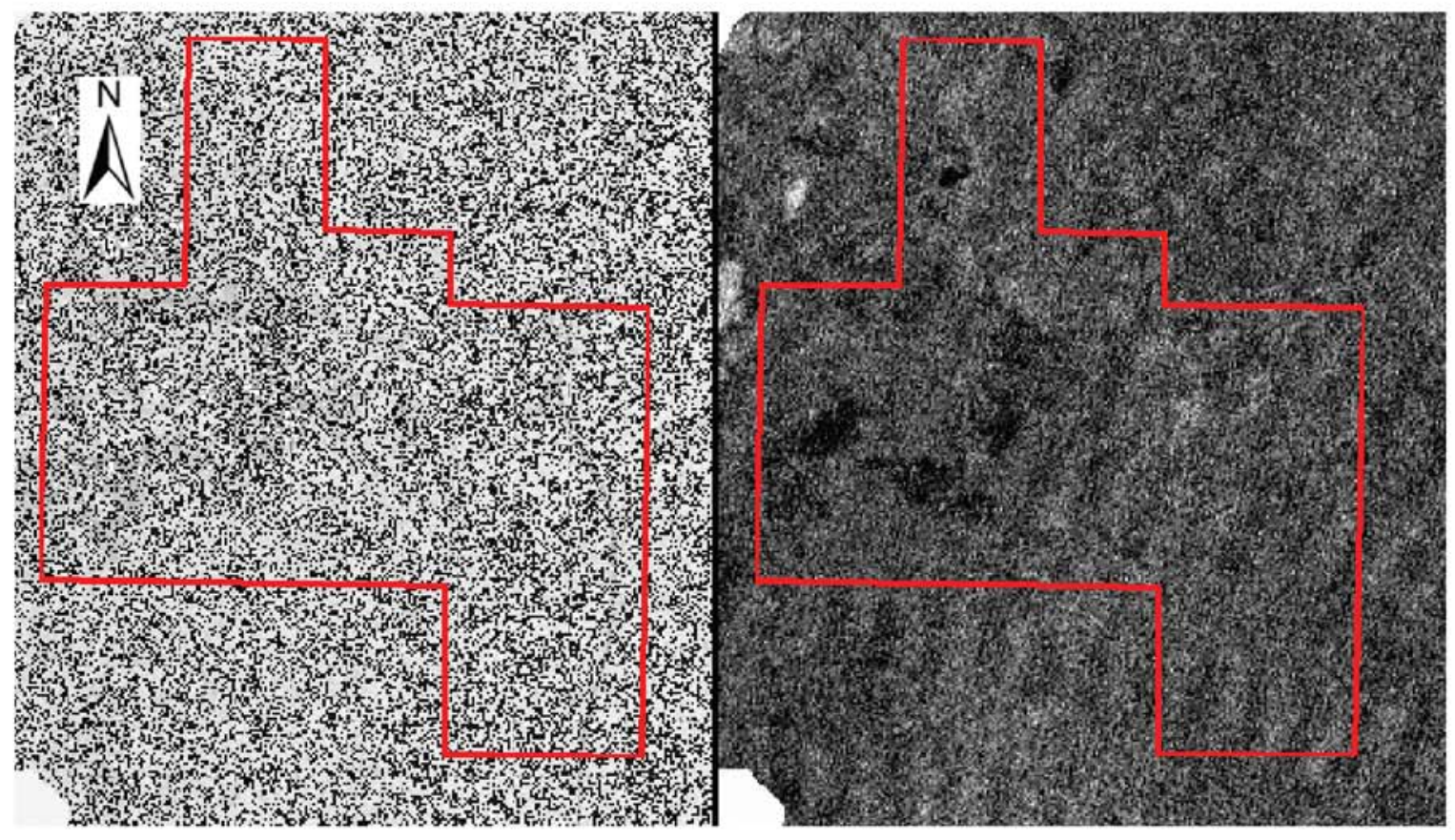

Figure 3.3 - Examples of removed components due to noise errors. Component 22 of the combined seasonal composite representing popcorned imagery (left) and component 16 of the same composite depicting noise error (right). 

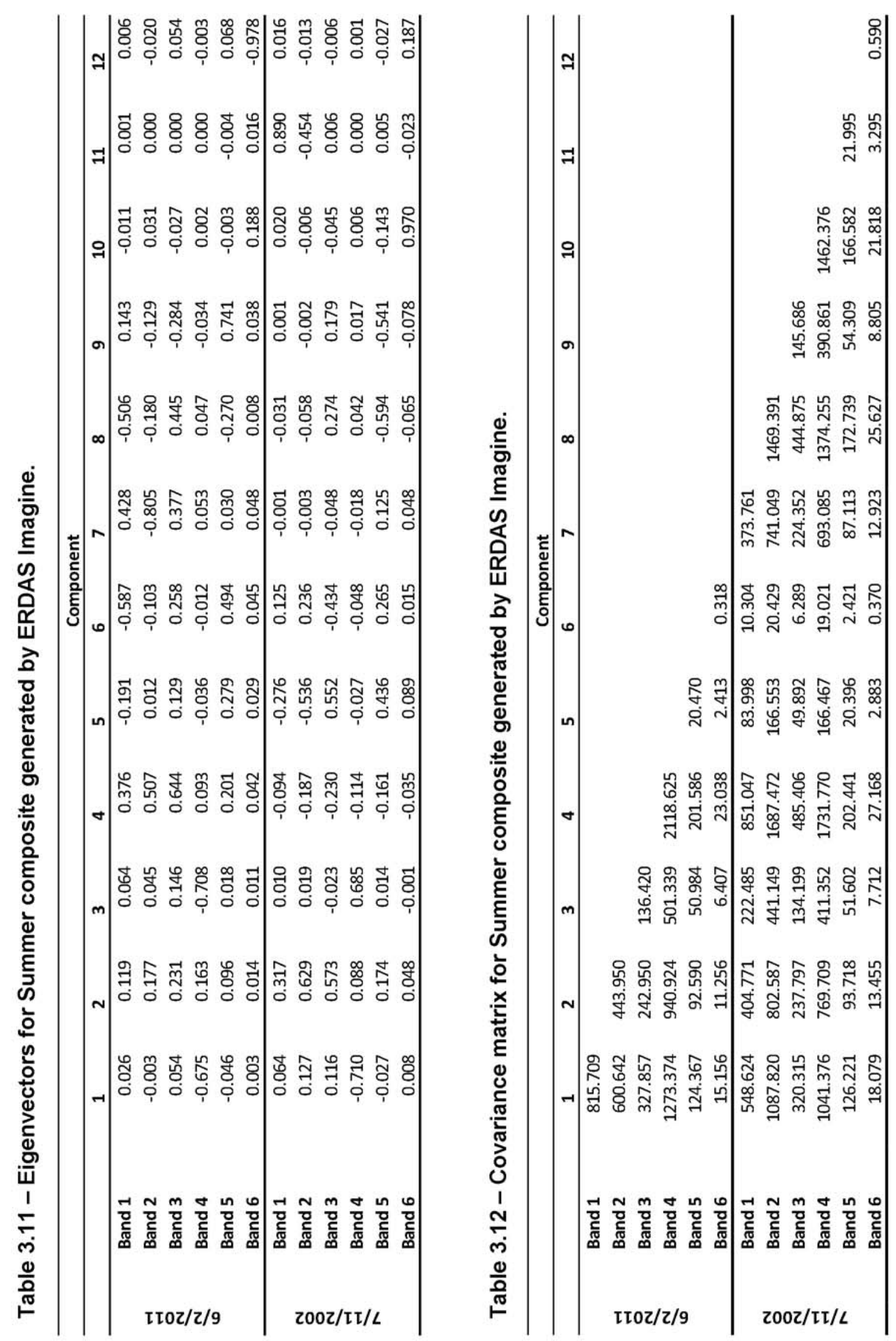

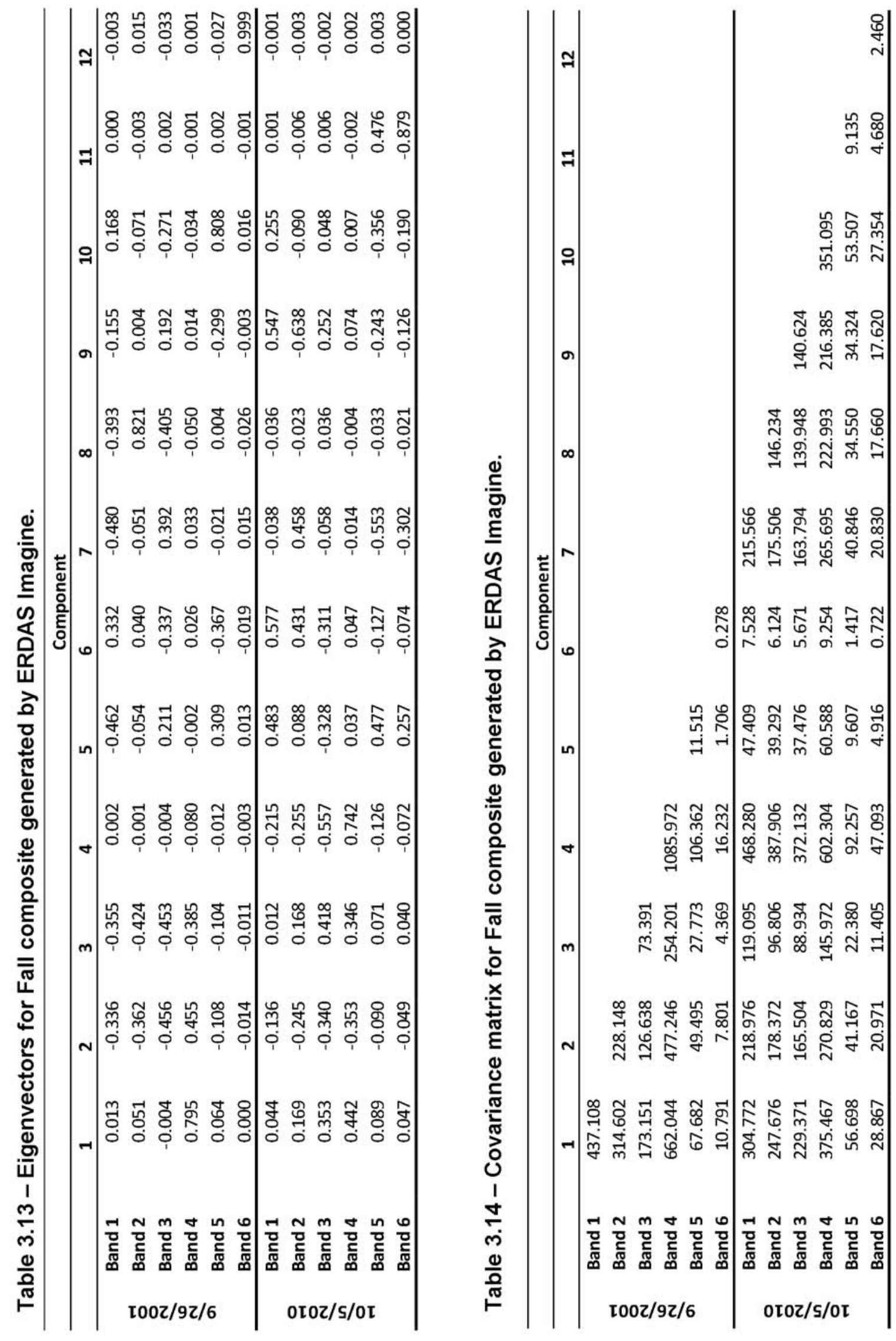


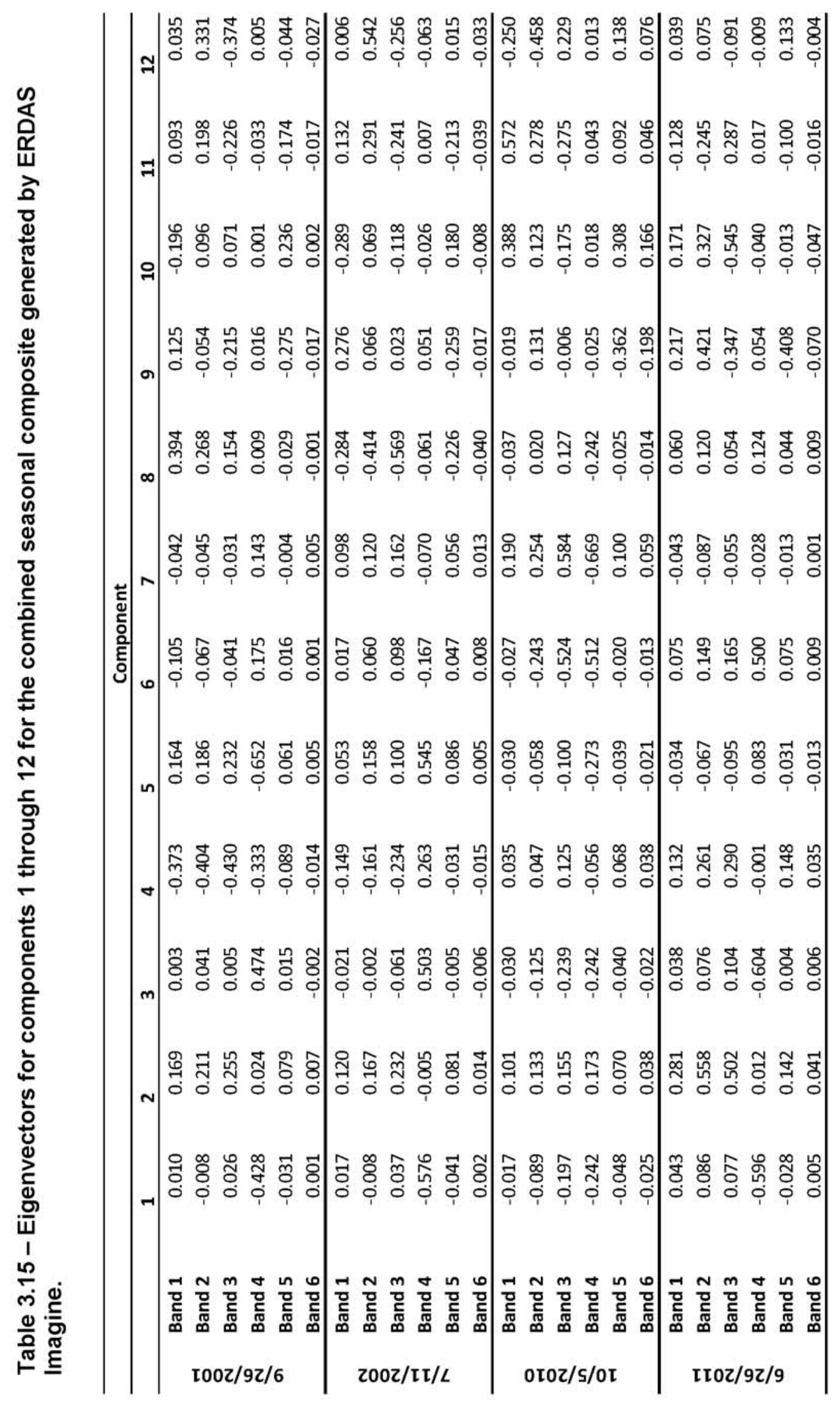




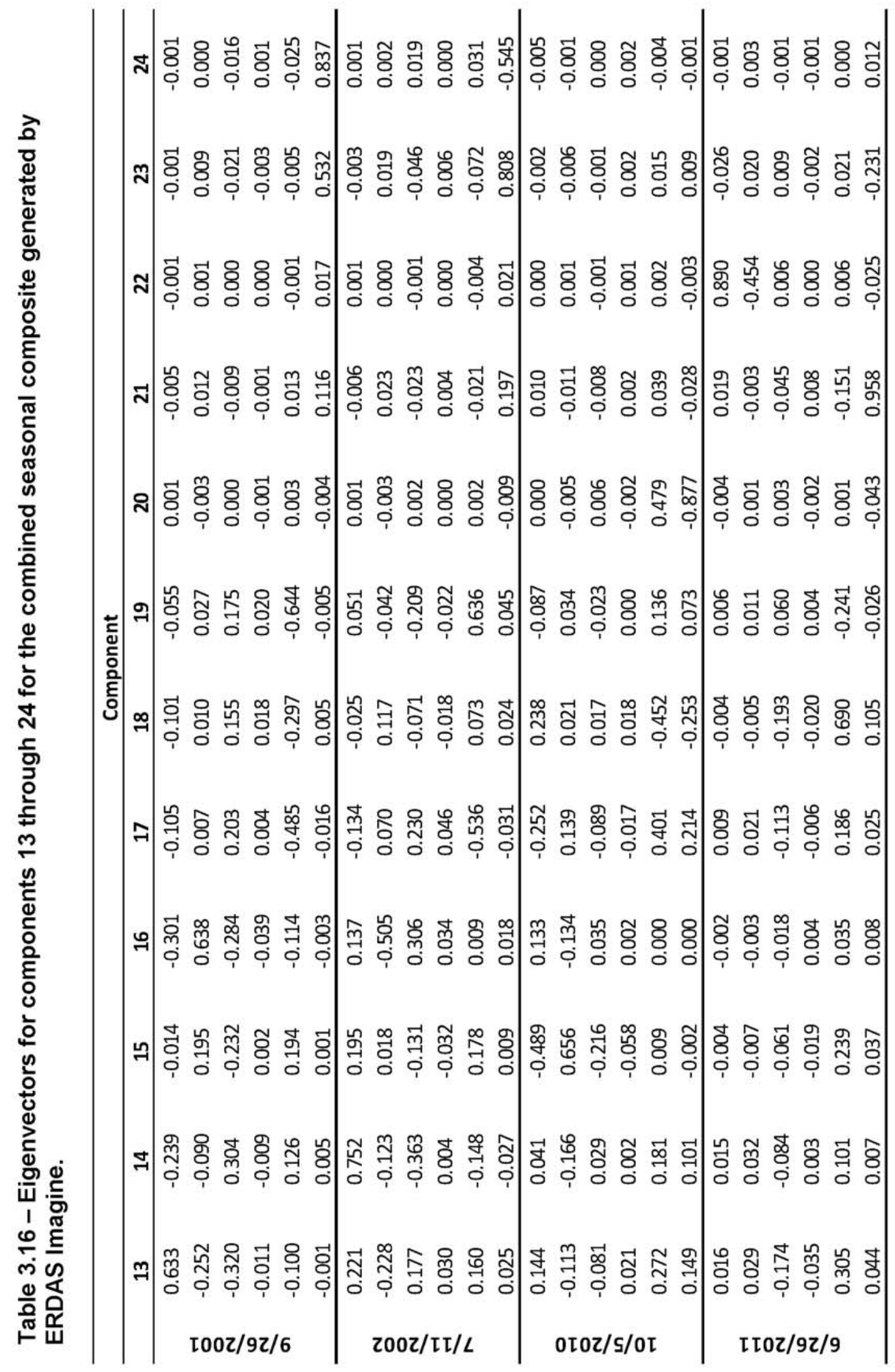




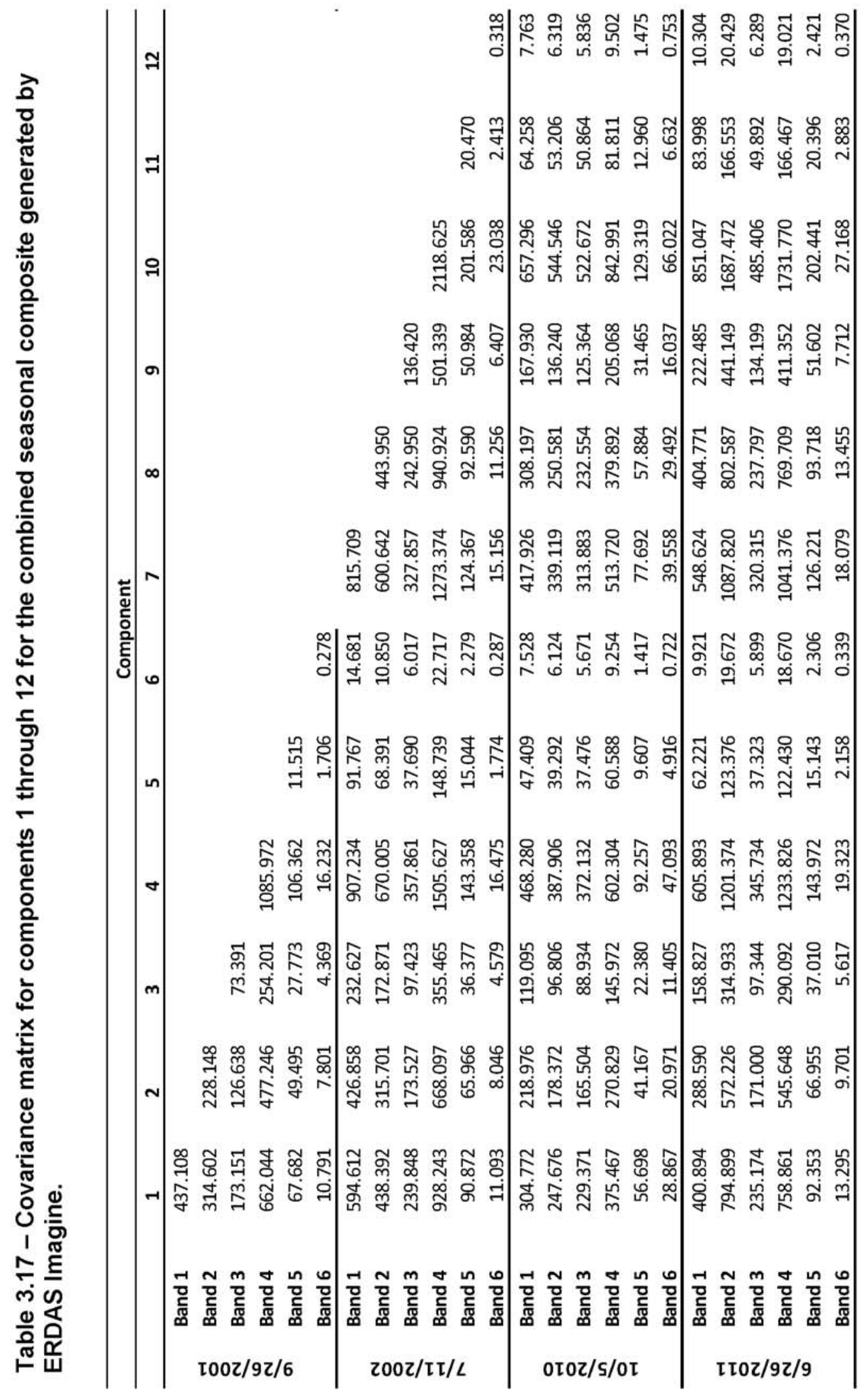




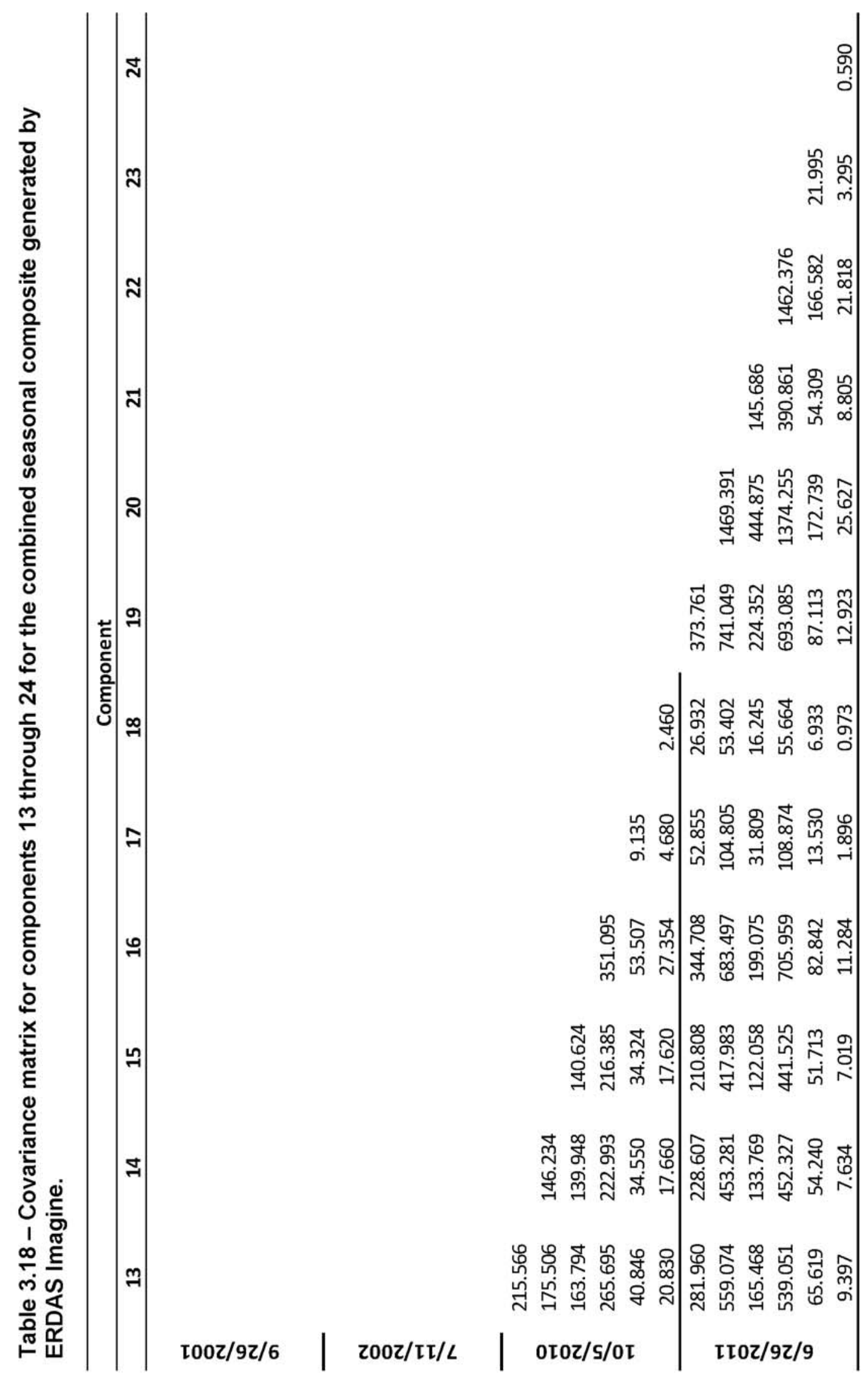




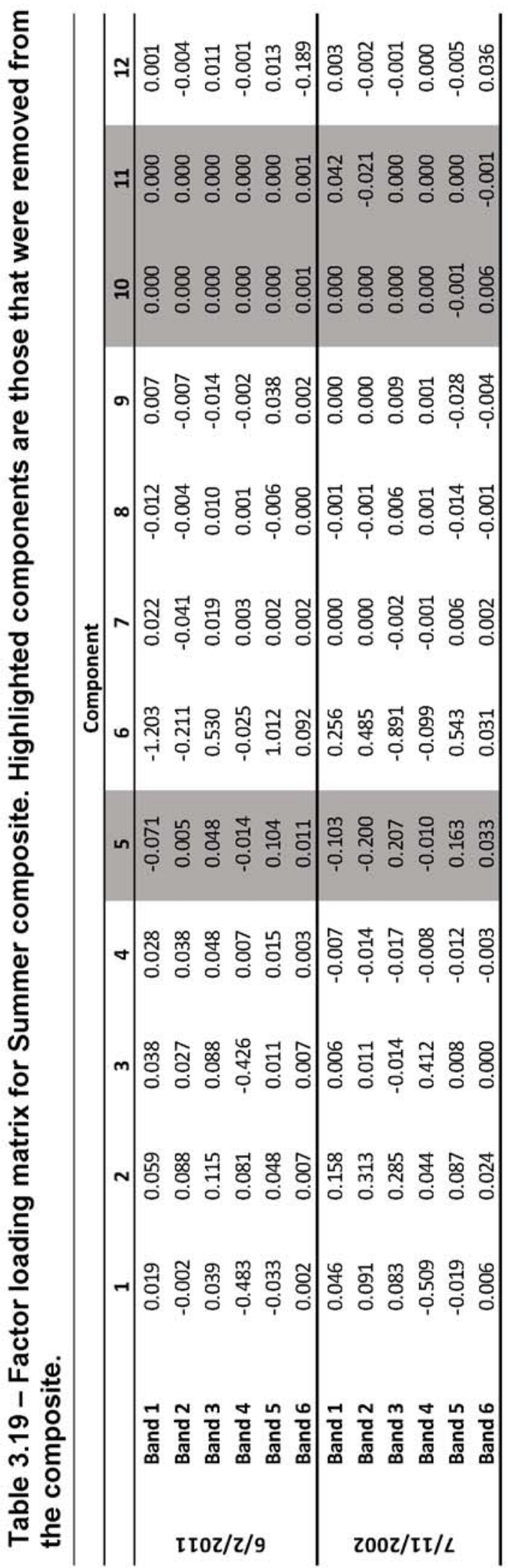




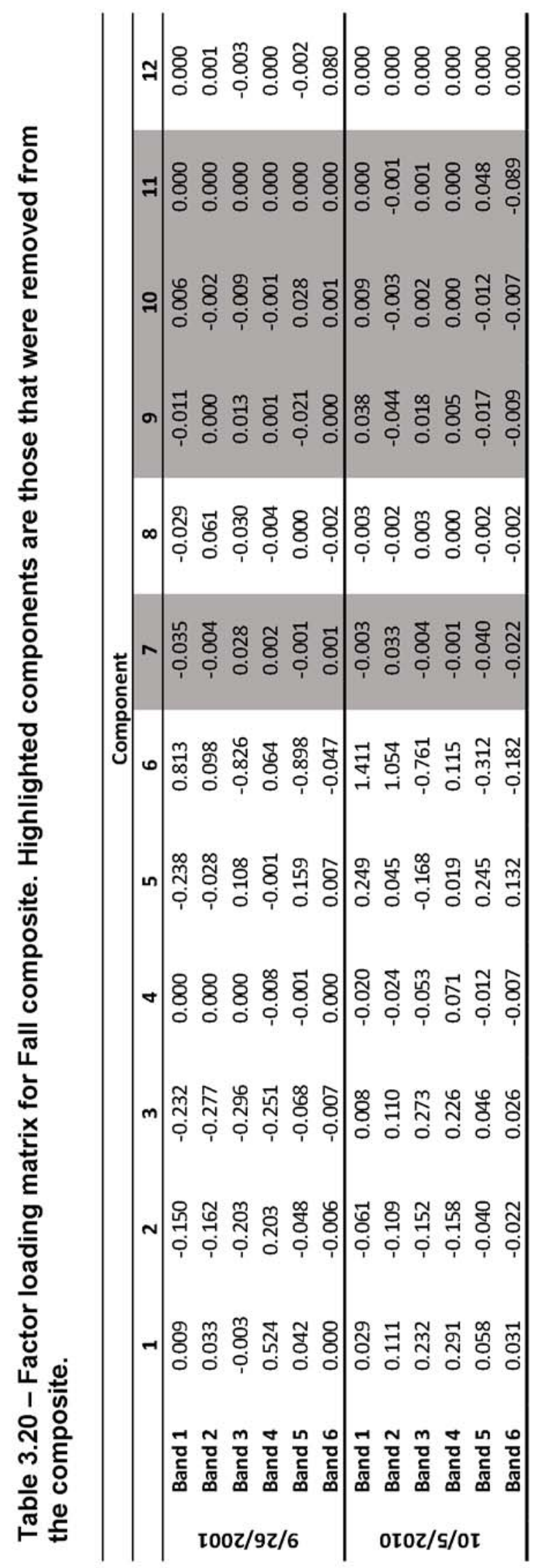




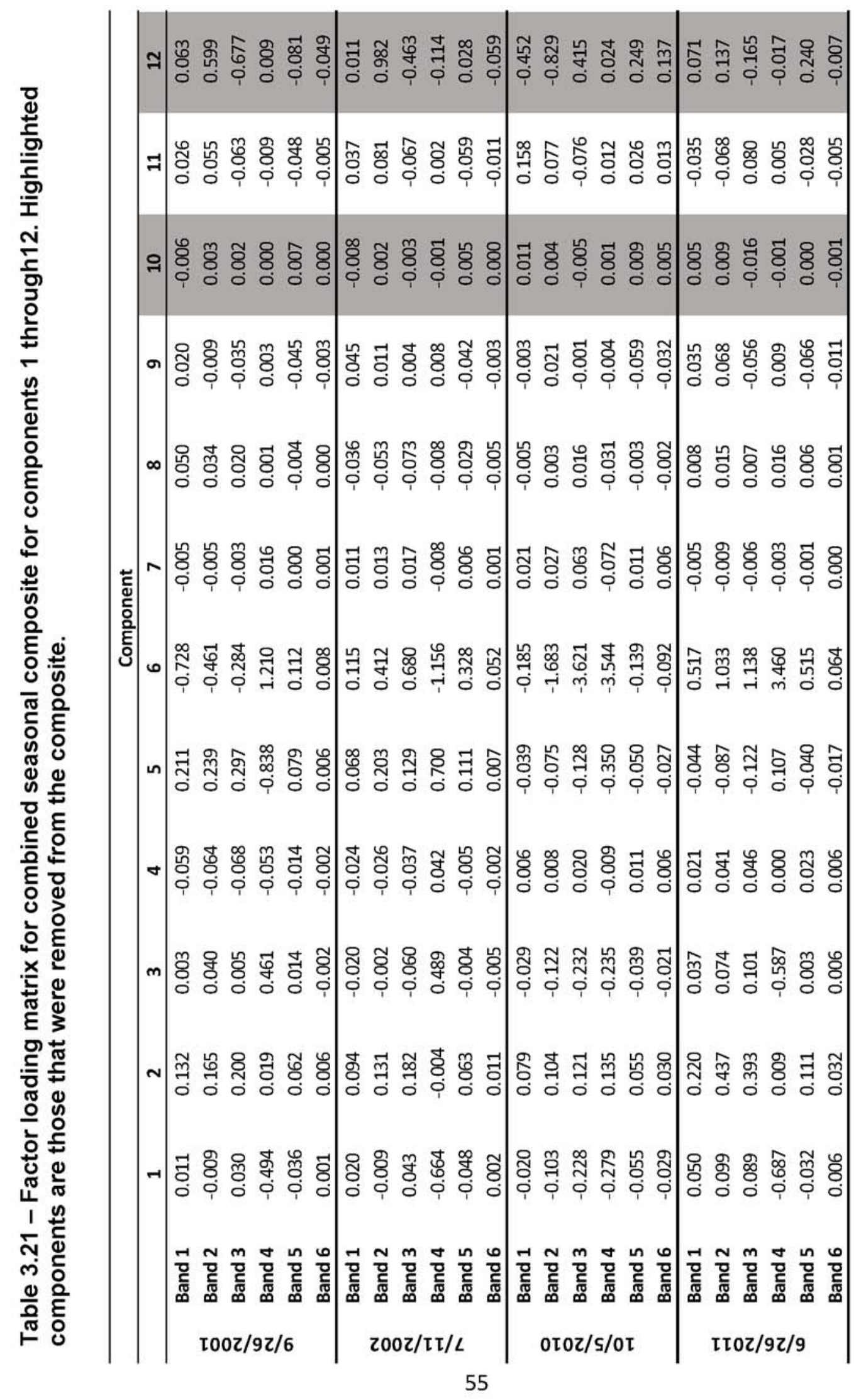




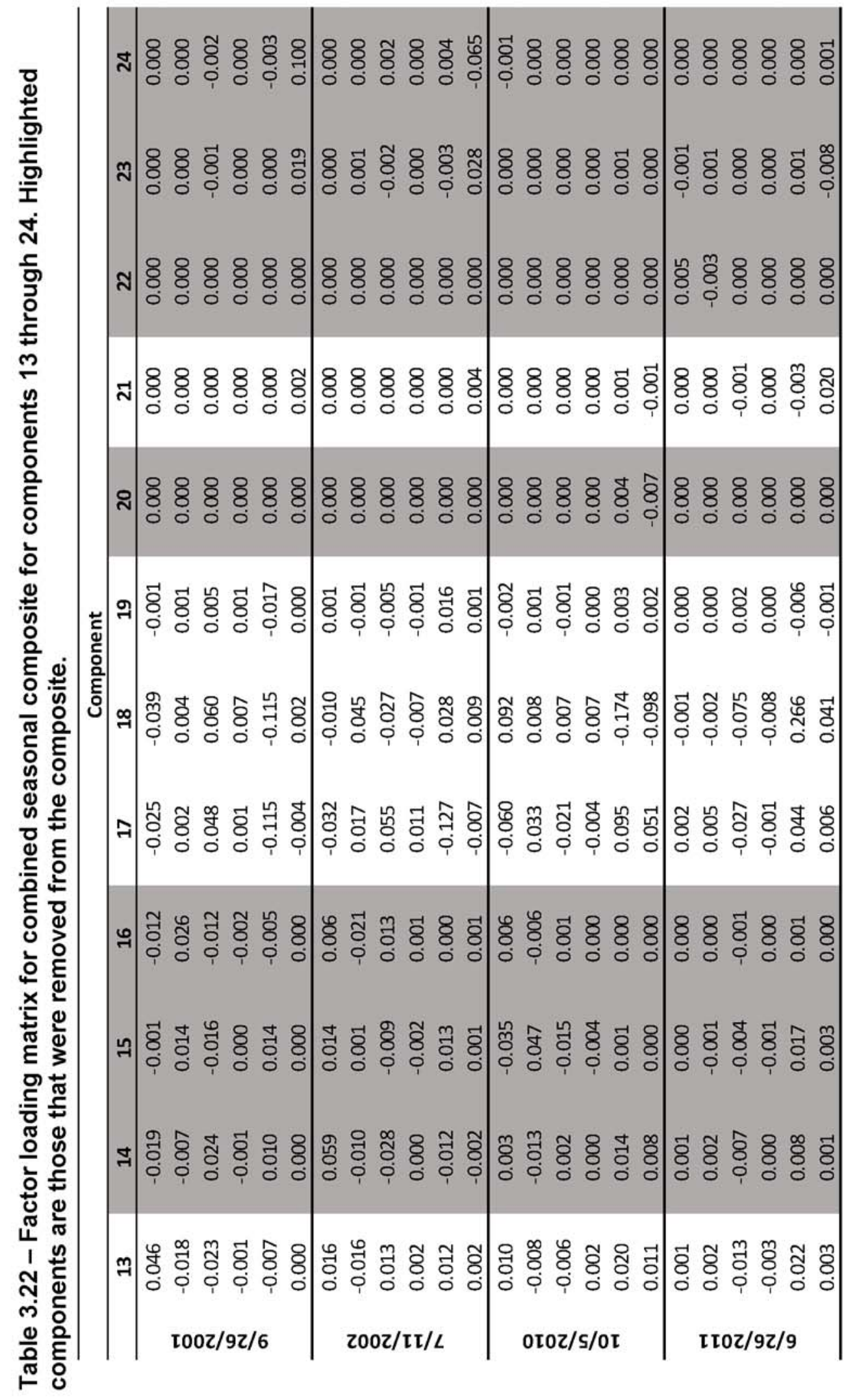




\subsubsection{Resulting Land Cover Map for Study Area}

Figure 3.4 depicts the final classification. After completion, the classification was saved as an img file in order that it could be imported into other programs for use. Enlargements of the classified image are depicted in Figure 3. 5 which also display the effect the $3 \times 3$ majority filter had on the final results and the reduction of the salt and pepper effect.

\subsubsection{Error Matrices}

Table 3.23 displays the error matrix which depicts the breakdown of points collected by information class for the entire image. Displaying how the ground data differed from the field collected accuracy points, the major diagonal axis, highlighted in yellow, shows how many of the field collected points were classified correctly for each category.

Table 3.23 - Maximum likelihood classification error matrix.

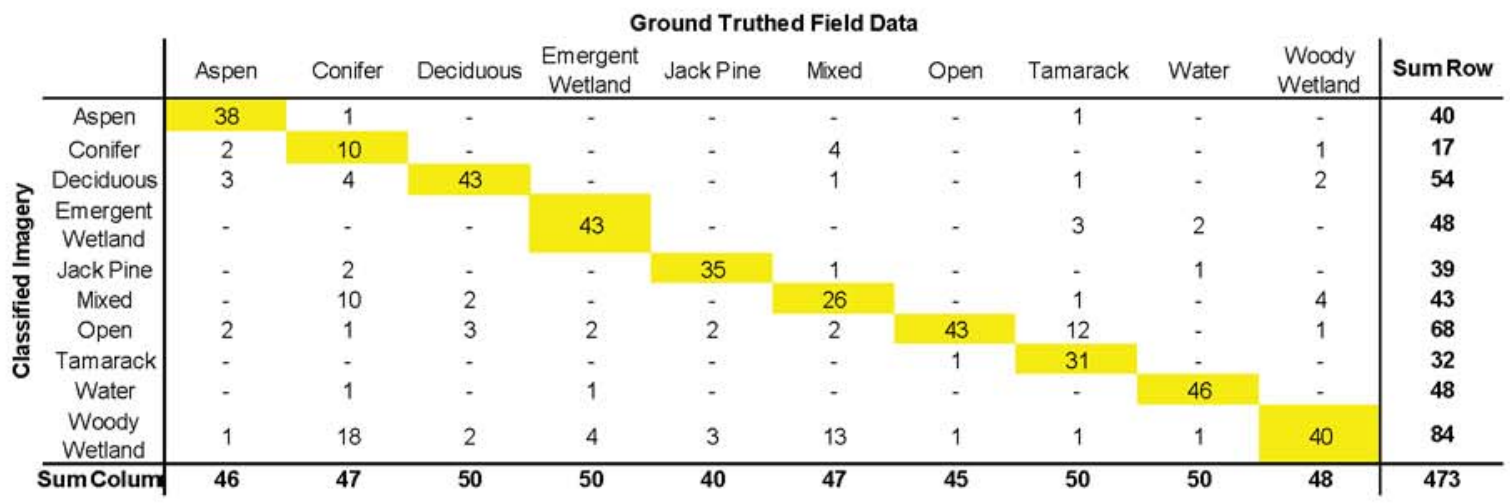




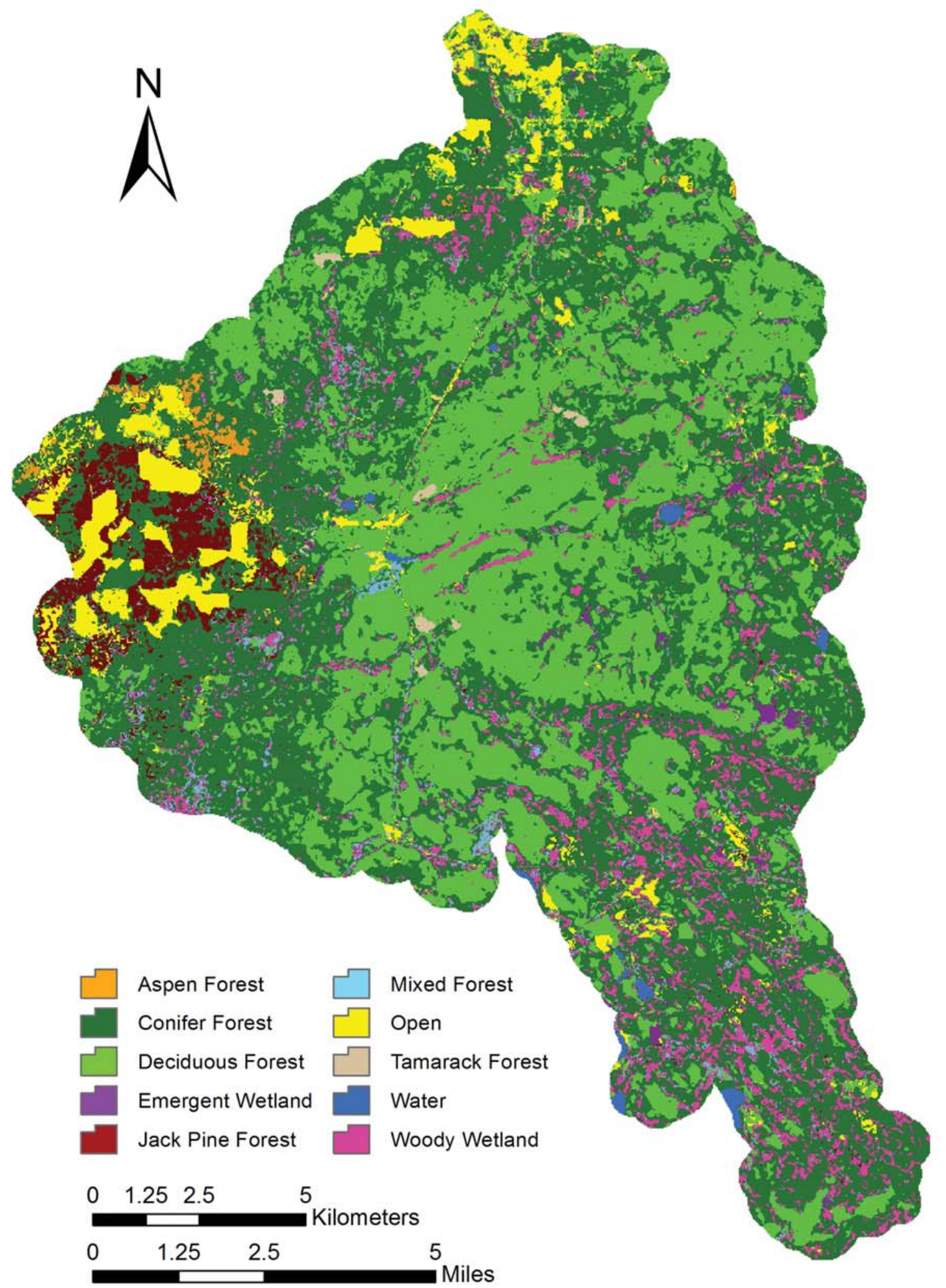

Figure 3.4 - Maximum likelihood classification of Landsat composite 

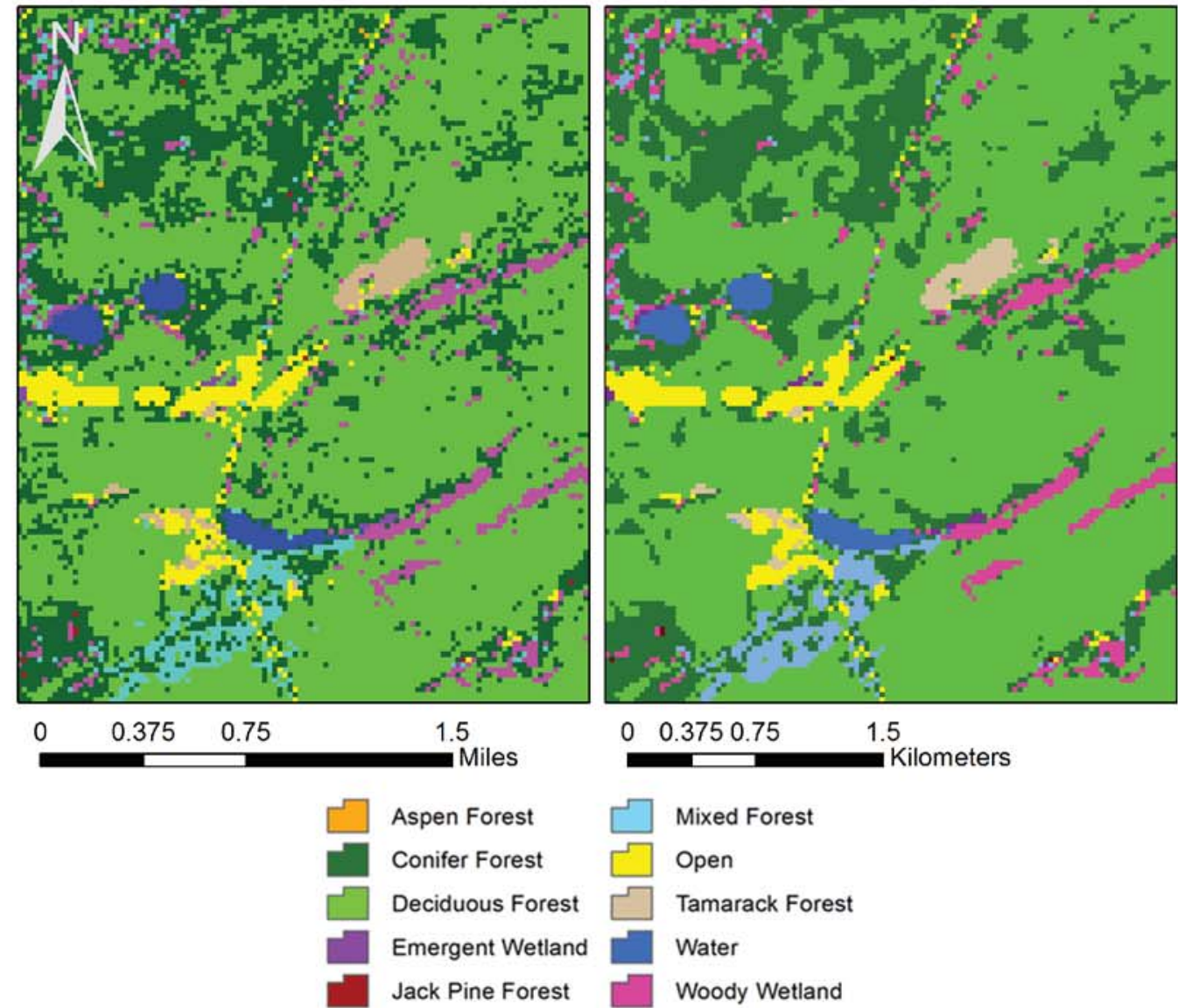

Kilometers

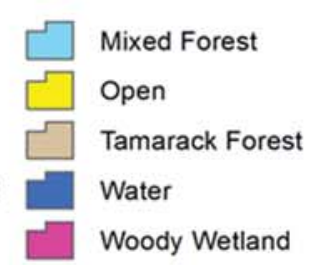

Figure 3.5 - Enlargements of maximum likelihood classification of Landsat composite near Alberta, Michigan before the $3 \times 3$ majority filter was run (left) and after (right).

The normalized error matrix used to calculate the Margfit analysis is depicted in percentages in Table 3.24. The major diagonal axis, again highlighted in yellow, represent the proportional percentage of points that were correctly classified in each information class. Overall the normalized values represent strong or moderate agreement between the classified points and the field accuracy data except for the Conifer class at $21.28 \%$ which indicates there is poor agreement. 
Table 3.24 - Normalized maximum likelihood classification error matrix.

\begin{tabular}{|c|c|c|c|c|c|c|c|c|c|c|}
\hline & \multicolumn{10}{|c|}{ Normalized Error Matrix } \\
\hline & Aspen & Conifer & Deciduous & $\begin{array}{l}\text { Emergent } \\
\text { Wetland }\end{array}$ & Jack Pine & Mixed & Open & Tamarack & Water & $\begin{array}{l}\text { Woody } \\
\text { Wetland }\end{array}$ \\
\hline Aspen & $82.61 \%$ & $2.13 \%$ & & & & & & $2.00 \%$ & & \\
\hline Conifer & $4.35 \%$ & $21.28 \%$ & & & & $8.51 \%$ & & & & $2.08 \%$ \\
\hline Deciduous & $6.52 \%$ & $8.51 \%$ & $86.00 \%$ & & & $2.13 \%$ & & $2.00 \%$ & & $4.17 \%$ \\
\hline $\begin{array}{l}\text { Emergent } \\
\text { Wetland }\end{array}$ & & & & $86.00 \%$ & & & & $6.00 \%$ & $4.00 \%$ & \\
\hline Jack Pine & & $4.26 \%$ & & & $87.50 \%$ & $2.13 \%$ & & & $2.00 \%$ & \\
\hline Mixed & & $21.28 \%$ & $4.00 \%$ & & & $55.32 \%$ & & $2.00 \%$ & & $8.33 \%$ \\
\hline Open & $4.35 \%$ & $2.13 \%$ & $6.00 \%$ & $4.00 \%$ & $5.00 \%$ & $4.26 \%$ & $95.56 \%$ & $24.00 \%$ & & $2.08 \%$ \\
\hline Tamarack & & & & & & & $2.22 \%$ & $62.00 \%$ & & \\
\hline Water & & $2.13 \%$ & & $2.00 \%$ & & & & & $92.00 \%$ & \\
\hline $\begin{array}{l}\text { Woody } \\
\text { Wetland }\end{array}$ & $2.17 \%$ & $38.30 \%$ & $4.00 \%$ & $8.00 \%$ & $7.50 \%$ & $27.66 \%$ & $2.22 \%$ & $2.00 \%$ & $2.00 \%$ & $83.33 \%$ \\
\hline
\end{tabular}

The overall accuracy of the final classification represents a moderate agreement between the classification and the field truthed ground data with a value of $75.05 \%$. The results of the Kappa analysis was slightly lower at $72.28 \%$ while the Margfit analysis was slightly higher at $75.16 \%$ though both still represent a moderate agreement (Table 3.25).

Table 3.25 - Overall statistics associated with the error matrix.

\begin{tabular}{cc}
\hline Assesment Method & Result \\
\hline Overall Accuracy & $75.05 \%$ \\
Kappa Analysis & $72.28 \%$ \\
Margfit analysis & $75.16 \%$ \\
\hline
\end{tabular}

Table 3.26 depicts the producer's and user's accuracy broken down by information class for the final classification. Once again there was considerably more variation in the accuracy values dependent on the information class and statistic being tested. Overall, each information class represents either a strong or moderate agreement between the classification and field accuracy points except for the Conifer class which had a producer's accuracy of $21.28 \%$ which represents a poor agreement. Another particularly low class was 
the Woody Wetland and Conifer user's accuracy at $47.62 \%$ and $58.82 \%$, respectfully, as well as the Mixed producer's accuracy at $55.32 \%$. While these three values still represent moderate agreement, they are still on the lower end of the value range.

Table 3.26 - Producer's and user's accuracy statistics associated with the error matrix.

\begin{tabular}{ccc}
\hline Classification Category & Producer's Accuracy & User Accuracy \\
\hline Aspen & $82.61 \%$ & $95.00 \%$ \\
Conifer & $21.28 \%$ & $58.82 \%$ \\
Deciduous & $86.00 \%$ & $79.63 \%$ \\
Emergent Wetland & $86.00 \%$ & $89.58 \%$ \\
Jack Pine & $87.50 \%$ & $89.74 \%$ \\
Mixed & $55.32 \%$ & $60.47 \%$ \\
Open & $95.56 \%$ & $63.24 \%$ \\
Tamarack & $62.00 \%$ & $96.88 \%$ \\
Water & $92.00 \%$ & $95.83 \%$ \\
Woody Wetland & $83.33 \%$ & $47.62 \%$ \\
\hline
\end{tabular}

\subsection{Discussion}

\subsubsection{Accuracy assessment}

Overall the maximum likelihood classification for the multiple classification technique worked rather well. Utilizing multiple images from two seasons enabled the extraction of far more data than using a single scene would have. By using the multiple scenes, more overstory species were able to be extracted and classified correctly generating a more useful classification map for land owners.

However, there was still considerable classification confusion between overstory species, especially between the Conifer and Woody Wetland classes. This was likely due to the amount of black spruce found within the Woody Wetland class being spectrally similar to species found within the Conifer class. Additionally, as the species in question were all 
evergreens, there would have been little difference between the summer and fall images for these classes which would not improve the classification. The same issue occurred where there was confusion between the Mixed and Woody Wetland classes also likely due to the same situation.

\subsubsection{Potential sources of error and variability}

Again, while attempts were made to reduce bias and error across the data collection and processing, there are still potential sources of error that should be mentioned. While the points were randomly generated via stratified random sampling, a total of 27 points were located on land that was either posted as private land or areas that were otherwise inaccessible. This left portions of the westernmost area of the image largely unverified and it is uncertain how accurate the classification is for that part of the study site.

Another possible source of error is the imagery acquisition dates. Since cloud free imagery was required, the relevant scenes were spread out over ten years. With the most recent image acquisition being in 2011 and the field accuracy points being collected in 2015 , there is some discrepancy between what is shown on the composite versus what is found in the field. This is not a problem unique to this study and must be considered anytime historical imagery is utilized. It is commonly accepted that there is 10 year window when change can be detected in the field and needed corrections made determining what past conditions were (Maclean and Cleland, 2003).

\subsection{Conclusions}

For larger scale, lower spatial resolution imagery, the maximum likelihood classification method produced the highest overall accuracy. While it would be best if imagery could be collected in the same year and at approximately the same time as data 
collection, utilizing the multi-temporal Landsat TM data with multiple seasons and years still managed to do an excellent job classifying the area of interest. Additionally, the combination of unsupervised and supervised classification greatly improved classification ease as the user was not limited to attempting to find the 'perfect pixels' to represent each information class. 


\section{CHAPTER 4}

\section{APPLICATION OF THE RIPARIAN BUFFER DELINEATION MODEL ON THE HICKEY CREEKISTURGEON RIVER AND}

FALLS RIVER WATERSHEDS

\subsection{Introduction}

The word riparian comes from the ancient Latin word ripa, commonly translated as 'the bank of a stream' which was further modified in the $6^{\text {th }}$ to $10^{\text {th }}$ century by the church to the uncommonly used word ripensis which means 'situated or stationed on a river bank' (Lewis and Short, 1956). However, in the modern age the precise nature of what a riparian area is can vary greatly. Research by Verry et al. (2004) notes the history and variety of definitions used to define a riparian ecotone. However, these definitions vary greatly depending on region, agency, and scientific discipline. For this project the definition by the USDA in their 2004 amended Forest Service Manual is used. The manual defines a riparian ecosystem as "a transition area between the aquatic ecosystem and the adjacent terrestrial ecosystem; identified by soil characteristics or distinctive vegetation communities that require free or unbound water." This definition was chosen because it takes into consideration the concept that both flora and soils can be used to identify and define the riparian ecotone.

The idea that riparian ecotones are transitional areas defined by their soils, flora, and proximity to running water is affirmed in other studies (Brosofske, 1997; National Research Council, 2002; Naiman et al., 2005) yet the question as to how to best define riparian ecotones in the field remains. Traditionally, state resource management agencies have 
relied on voluntary best management practices (BMPs) for forested or agricultural lands but these guidelines vary greatly by state. For Michigan, the BMPs are based on a fixed width buffer around the river or stream that varies dependent on slope. Within the buffered area, activity is discouraged or landowners are advised to take extra precautions in order to protect water quality (Michigan DNR, 2009).

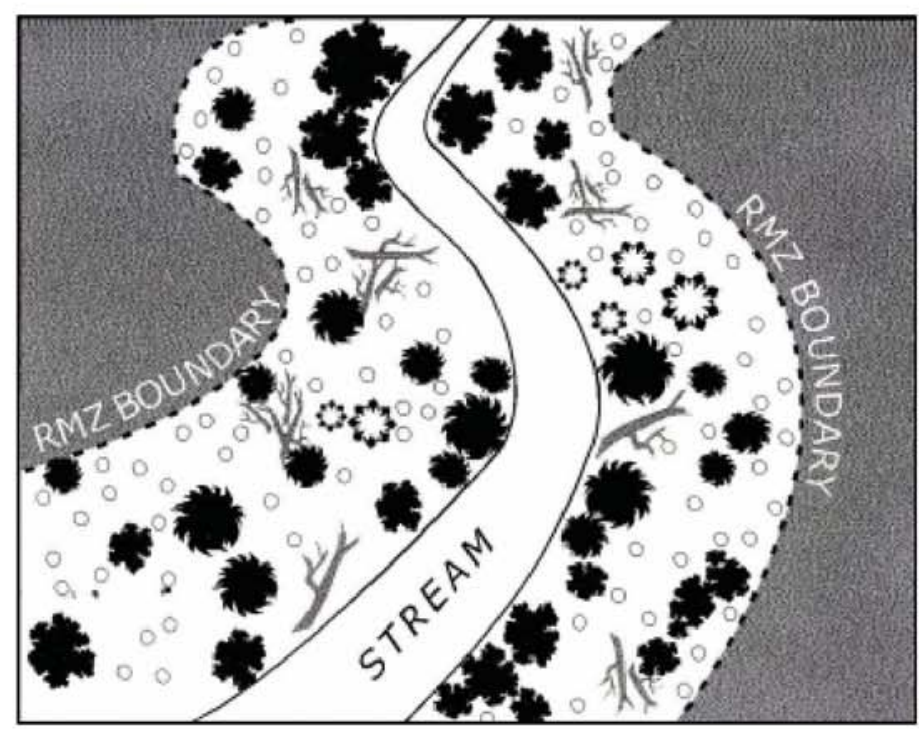

Figure 4.1: Example of a riparian buffer zone utilizing Michigan best management practices (BMPs) taken from the Michigan DNR Sustainable soil and water quality practices on forest land manual.

While fixed width buffers are easy to apply in the field, studies have shown that this approach does not always include the entire riparian ecotone (Lee et al., 2004; MacNally et al., 2008). With the advent of geospatial programs such as ArcMap® it has become easier to create realistic and more accurate variable-width buffers. The work by Aunan et al. (2005) was one of the first to apply the principles published by llhardt et al. (2000) and Skally and Sagor (2001) to create a variable-width riparian buffer utilizing geospatial programs. However, their model was based solely on the topography surrounding the rivers and streams and they were limited to a 30 meter digital elevation model (DEM) which generated 
buffers that overestimated the area of the actual riparian ecotone. Holmes and Goebel (2011) also looked at the issue of generating variable-width buffers, but they were also hindered by the lack of availability of high spatial resolution DEMs. Their manually generated results did protect more of the riparian ecotone than a fixed width buffer, but the process to generate the buffer is exceedingly time-consuming, and again they were limited to using a 30 meter DEM. Mason (2007) and Abood (2011) evaluated the impact the DEM spatial resolution had on a variable-width riparian buffering model and found that results were dependent on the spatial resolution.

Utilizing the research completed by Mason (2007), Abood (2011) took the variablewidth topographic model and integrated soils, wetland, and landcover data sets to it. This model, takes into consideration not only the changes in elevation around the river or stream but also its soil and flora characteristics. While computationally intensive, this program is faster and more cost effective then field mapping riparian areas. Thus, the objective of this

project was to implement the model created by Abood on the Ford Research Forest lands, using it to identify riparian zones.

\subsection{Methods}

\subsubsection{The Riparian Buffer Delineation Model}

The Riparian Buffer Delineation Model (RBDM) utilizes ArcGIS $®$ Desktop 10.2 (ESRI 1999-2015). This program is used for all analyses, data input, and data management for the model. Additionally, ArcMap's Spatial Analyst extension must be available for the model to run. All data used by the model must be stored within a single ArcMap File Geodatabase (FGDB).

The RBDB Manual written by Maclean and Abood (2011) was closely followed for this project. A majority of the data used for this model is freely available from state or federal 
geospatial clearing houses, Table 4.1 shows which data inputs were used and their sources. The 2 meter LiDAR DEM is the property of the Geospatial Analysis Laboratory (GAL) of the MTU School of Forest Resources and Environmental Science. After downloading the requisite geospatial data it was clipped to the borders of the study area.

Table 4. 1 - Riparian Buffer Delineation Model data inputs and sources.

\begin{tabular}{cl}
\hline Input Data & \multicolumn{1}{c}{ Sources } \\
\hline $\begin{array}{c}\text { Streams, } \\
\text { Watersheds, Lakes }\end{array}$ & $\begin{array}{l}\text { The National Map Viewer } \\
\text { viewer.nationalmap.gov/ }\end{array}$ \\
\hline $\begin{array}{c}\text { National Wetland } \\
\text { Inventory }\end{array}$ & $\begin{array}{c}\text { National Wetlands Inventory (NWI) } \\
\text { http://www.fws.gov/wetlands/data/Mapper.html }\end{array}$ \\
\hline Digital Soil Data & $\begin{array}{l}\text { USDA - Web Soil Survey } \\
\text { http://websoilsurvey.sc.egov.usda.gov/ }\end{array}$ \\
\hline $\begin{array}{c}\text { 2m Digital Elevation } \\
\text { Model }\end{array}$ & Michigan Technological University \\
\hline $\begin{array}{c}\text { National Land Cover } \\
\text { Database }\end{array}$ & $\begin{array}{c}\text { The National Map Viewer } \\
\text { viewer.nationalmap.gov/ }\end{array}$ \\
\hline
\end{tabular}

There was an issue with the delineation of the streams and lakes layers downloaded from the National Map Viewer. These layers did not accurately represent the current ground conditions, most likely due to the layers being delineated using coarser spatial resolution imagery and/or DEMs. In order to correct for this issue the streams and lakes layers were re-digitized using the 2012 one meter image and a 1998 leaf-off three-band (MDNR) to correct stream and lake boundaries.

Model flood heights were taken from Abood et al. (2012) which suggested flood heights of $0.5 \mathrm{~m}$ and $1 \mathrm{~m}$ be used to represent minimum and average flood heights for watersheds in the Upper Midwest. For each model the 'Length of Transects Vector (Meters)' value was 203 meters. The model was run a total of four times for the study area, twice for each watershed at each of the designated flood heights. 
Abood et al. (2012) has a detailed explanation on how the RBDM processes data and generates its results. In summary the model creates sample points along the stream's watercourse. The distance between each sample point is calculated by the model to be $75 \%$ of the DEM's spatial resolution to avoid spatial autocorrelation. After the sample points are generated, transects are produced around each point for $360^{\circ}$. Once the transects are generated, the model compares the transect points to the initial sample point. If a transect point has an elevation change greater than the specified flood height, the transect point is considered to be outside of the riparian flood zone and deleted.

The model repeats this process for each sample point and every transect point until the riparian zone boundary is determined. The model then transforms the designated riparian zone into a raster, smooths the edges, and converts the raster into a vector polygon. A simple buffer of 30 meters is also placed around all stationary waterbodies such as lakes and ponds based on the recommendation by Verry et al. (2004). When the model is run, multiple feature classes are outputted that display buffer results based on various inputs. For the purposes of this project, the buffer results based on solely the topographic DEM and the complete model (which in addition to the DEM, incorporates hydric soil and wetland data) were compared to determine the riparian zone.

\subsubsection{Data Collection}

Streams in the study area were walked to determine the riparian corridor based on field conditions. The riparian corridor was determined by a variety of conditions, but was primarily delineated by understory vegetation, overstory cover, and soil moisture. A Trimble Juno $3 \mathrm{~B}$ unit was used to automatically track the walked path with a progress point taken every 30 seconds. While the user attempted to stay directly on the border between riparian and upland ecosystems, occasionally a buffer had to be put around the riparian zone due to 
terrain changes or other ground conditions. This occurred most notably around the Surgeon River (Figure 4.2) due to portions of the river having steep rugged slopes and other sections bounded by a wide wet floodplain.

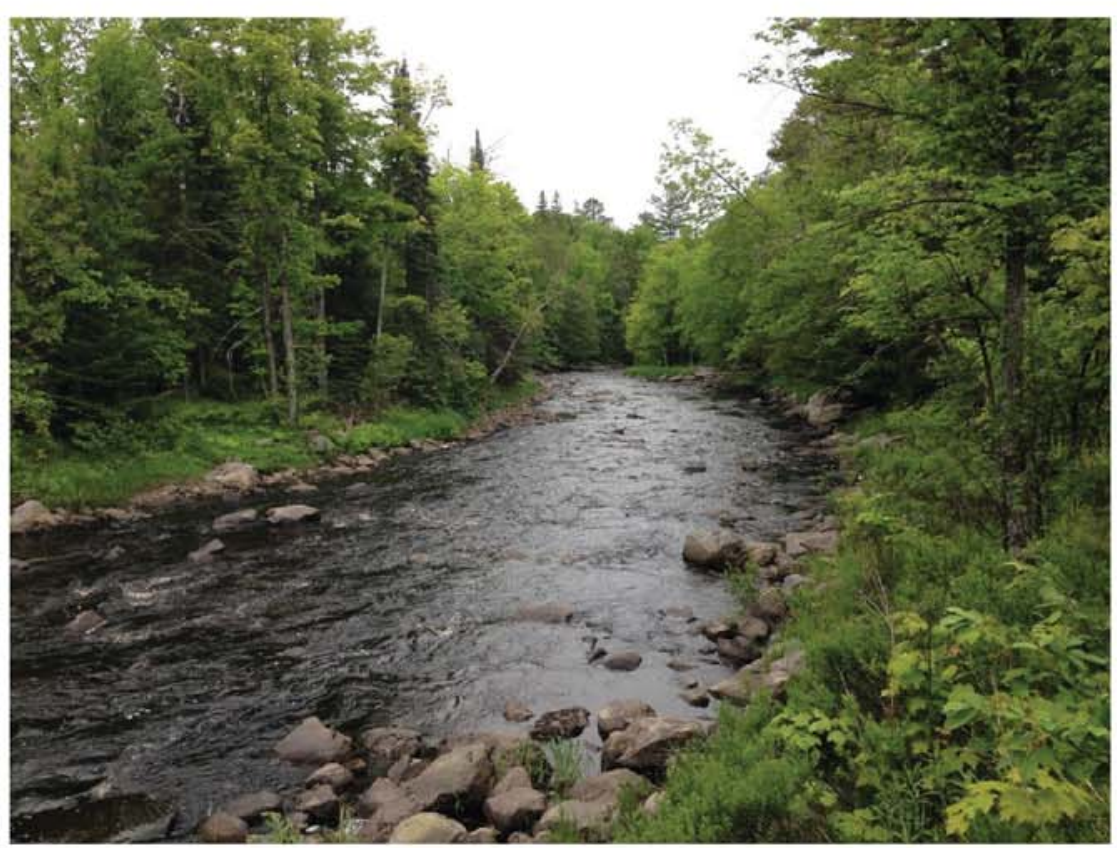

Figure 4.2 - The Sturgeon River, the largest river running through the study area.

Data collection was done from late May to mid June 2014 to capture the growth and flowering of the spring ephemerals before their summer senescence. The edges of the riparian zone were determined by the presence and absence of various ground flora species as well as presence of absence of various overstory species as well. Riparian corridor species included but were not limited to jack-in-the-pulpit (Arisaema triphyllum) (Figure 4.3), cinnamon fern (Osmunda cinnamomea) (Figure 4.3), marsh marigold (Caltha palustris) (Figure 4.4), sensitive fern (Onoclea sensibilis), ostrich fern (Pteretis pensylvanica), and duck-potato (Sagittaria latifolia). Upland species included but were not limited to yellow bead lily (Clintonia borealis) (Figure 4.5), false solomon's seal (Maianthemum racemosum) 
(Figure 4.5), interrupted fern (Osmunda claytoniana) (Figure 4.6), nodding trillium (Trillium cernuum) (Figure 4.6), partridge berry (Mitchella repens), and large-leaf aster (Eurybia macrophylla).
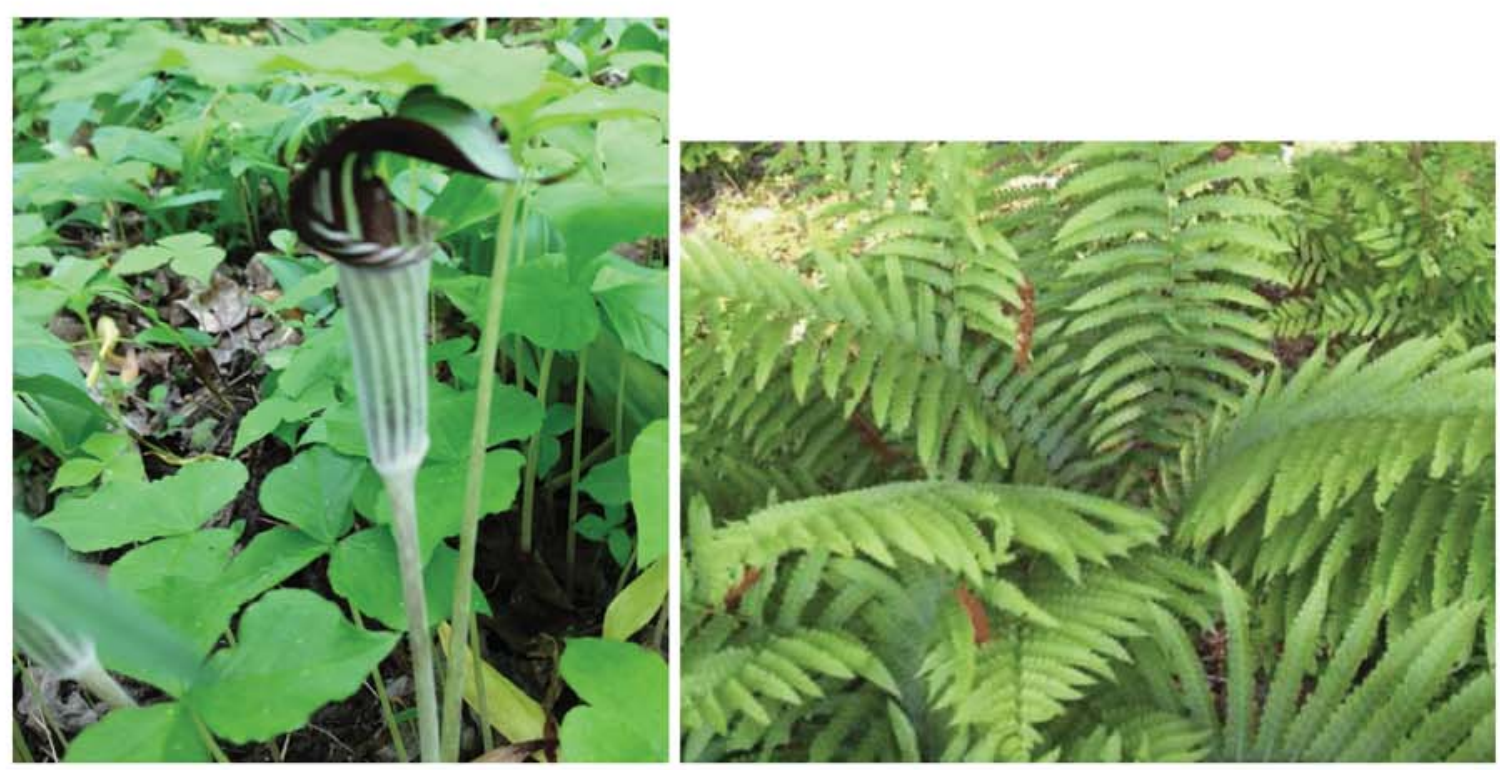

Figure 4.3 - Riparian corridor species found on the Ford Research Forest lands. Jack in the pulpit (left), cinnamon fern (right).

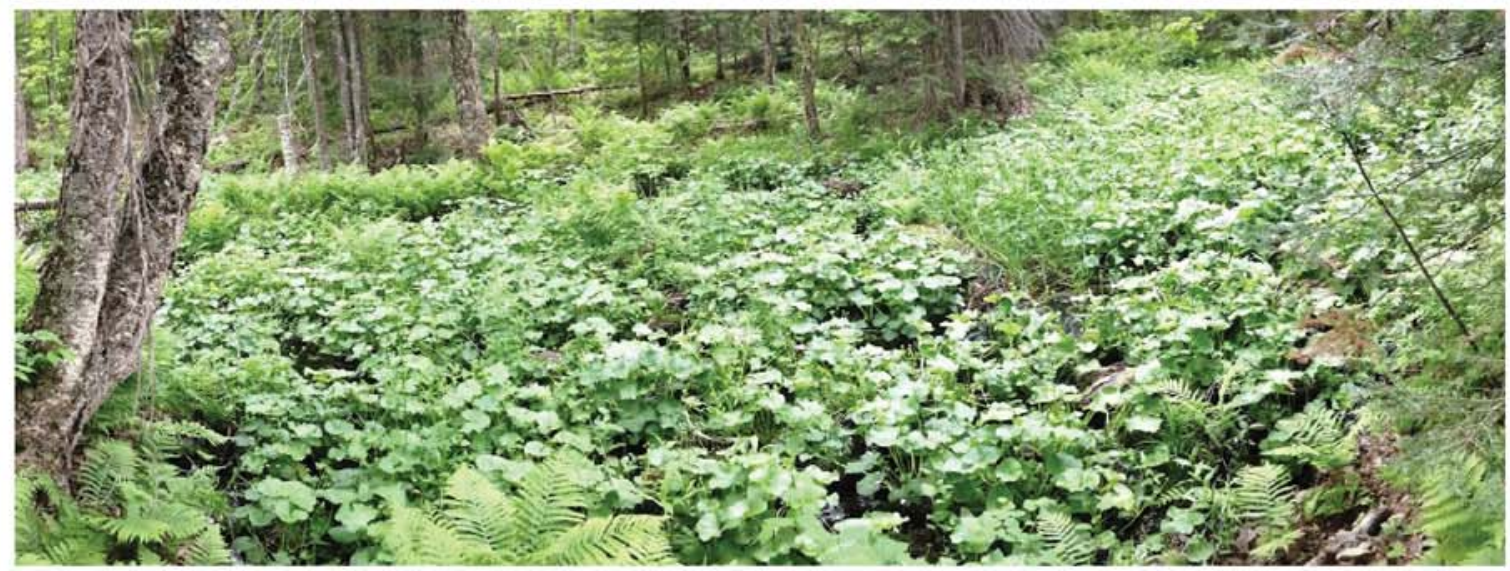

Figure 4.4 - Marsh marigold found on the Ford Research Forest 


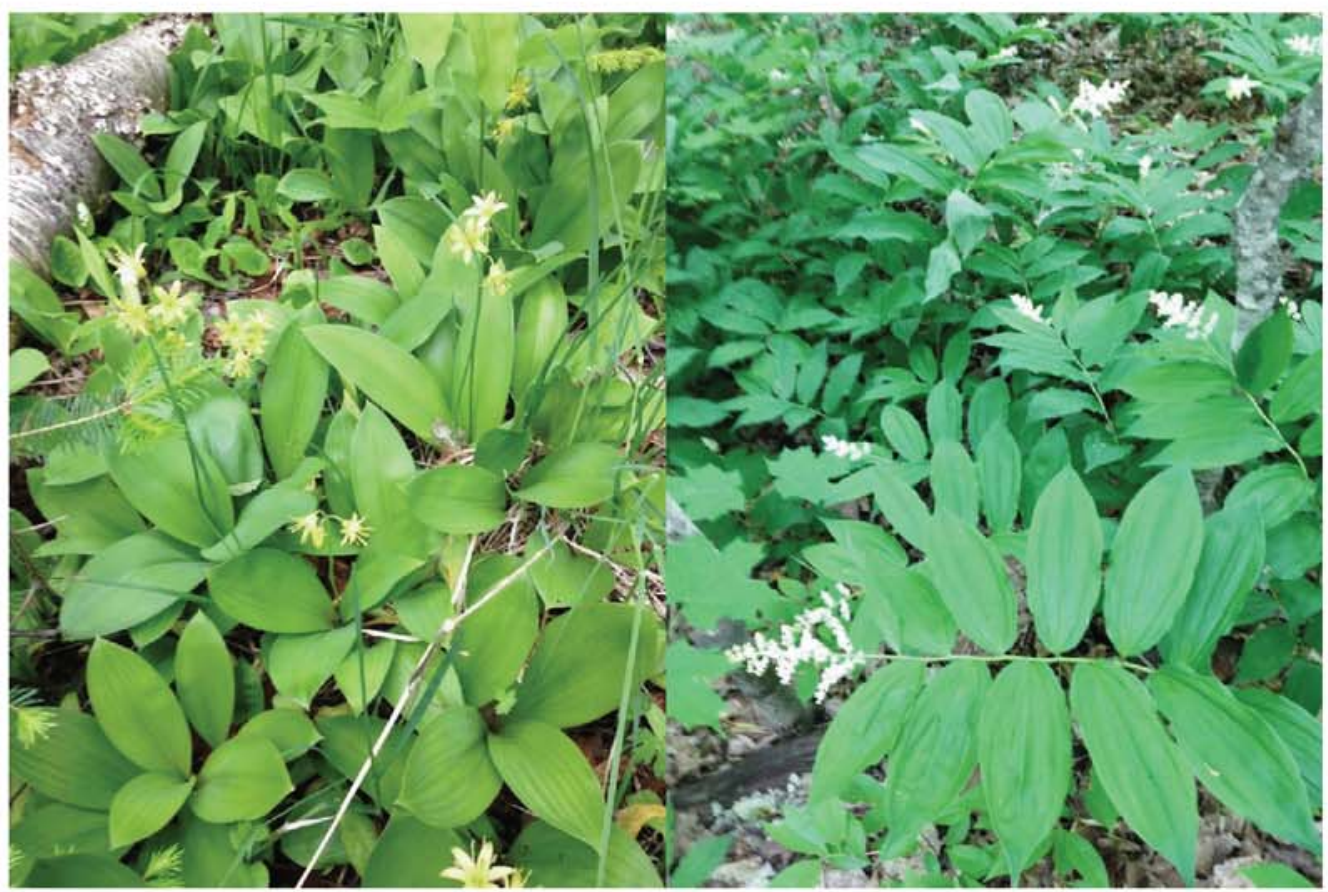

Figure 4.5 - Upland species found on the Ford Research Forest. Yellow bead lily (left), false solomon's seal (right).

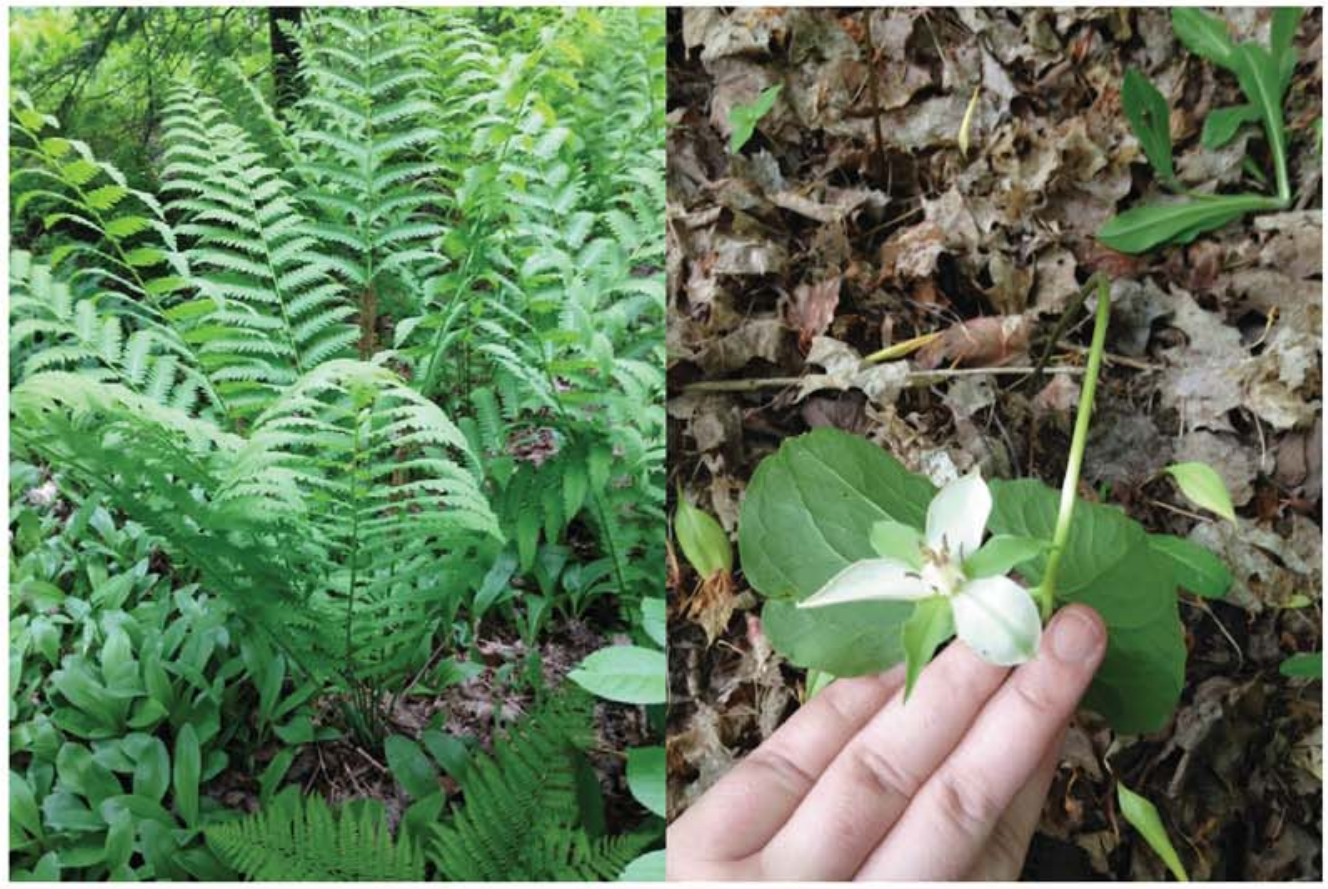

Figure 4.6 - Additional upland species found on the Ford Research Forest. Interrupted fern (left), nodding trillium (right). 
Besides the riparian zone delineated by the RBDM, a simple fixed width buffer of 100 feet was generated around the streams to represent the guidelines suggested by MDNR Best Management Practices. The results of the RBDM, fixed width buffer, and the walked riparian zone were then clipped to the study area and their area calculated via ArcMap.

\subsection{Results}

Primary attention was paid to sections 18,19 , and 30 of the Ford Research Forest as these areas were most affected by rivers and streams. Figures $4.7,4.8$, and 4.9 show the riparian buffer calculated from the 1 and $0.5 \mathrm{~m}$ flood heights RDBM model compared with the fixed width buffer and field mapped riparian corridor for the Sturgeon River and Plumbago Creek areas. The total area included within these zones is displayed in Table 4.2. The results of the RDBM labeled as 'elevation' depict the results generated by the model which only take into account topographic elevation change in the DEM while the results labeled as 'complete' take into account the full model which includes hydric soils and wetland feature classes.

Table 4.2 - RDBM, fixed width buffer, and riparian zone results (in hectares) for the Ford Research Forest properties.

\begin{tabular}{lcccc}
\hline \multicolumn{1}{c}{ Model } & & & Sturgeon River \& & \\
Ogemaw Creek & Plumbago Creek & Unnamed Creeks & Total \\
\hline Fixed width 100 ft buffer & 3.5 & 5.6 & 37.6 & 46.7 \\
RDBM - 1 m, elevation & 3.3 & 19.9 & 46.2 & 69.4 \\
RDBM - 1m, complete & 3.3 & 19.9 & 59.9 & 83.1 \\
RDBM - 0.5 m, elevation & 2.6 & 12.3 & 23.3 & 38.2 \\
RDBM - 0.5m, complete & 2.6 & 12.4 & 46.0 & 61 \\
Field mapped riparian zone & 2.9 & 6.7 & 51.1 & 60.7 \\
\hline
\end{tabular}

Overall, the results of the RDBM model found that the fixed width buffer leaves out a considerable amount of potential riparian land. The Plumbago Creek area is where this was 
most evident with the fixed width buffer encompassing only 5.6 hectares while the RDBM 0.5 meter, elevation only results were 12.3 hectares and the RDBM 1 meter, elevation only results were 19.9 hectares. However, in the Ogemaw Creek area the RDBM actually encompassed less land with the 1 meter, elevation only results being 3.3 hectares and the 0.5 meter, elevation only results were 2.6 hectares while the fixed width buffer encompassed 3.5 hectares of land.

The effect of the complete RDBM was most evident in the Sturgeon River and unnamed creek area. When the model was run only utilizing elevation values the 0.5 meter and 1 meter results were 23.3 and 46.2 hectares, respectfully. After including wetland and hydric soil information into these results the numbers increased to 46.0 and 59.9 hectares. 


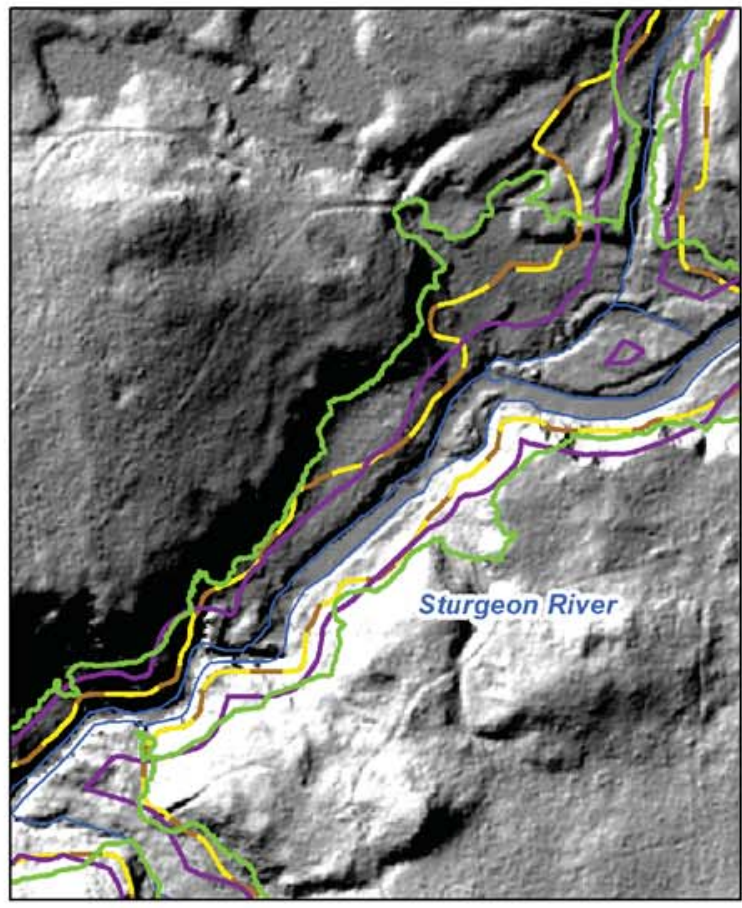

RDBM - 1m, elevation only

3 RDBM - $1 \mathrm{~m}$, complete model

$\sim$ RDBM $-0.5 \mathrm{~m}$, elevation only

RDBM - $0.5 \mathrm{~m}$, complete model

$0.050 .1 \quad 0.2$

0.2 Kilometers

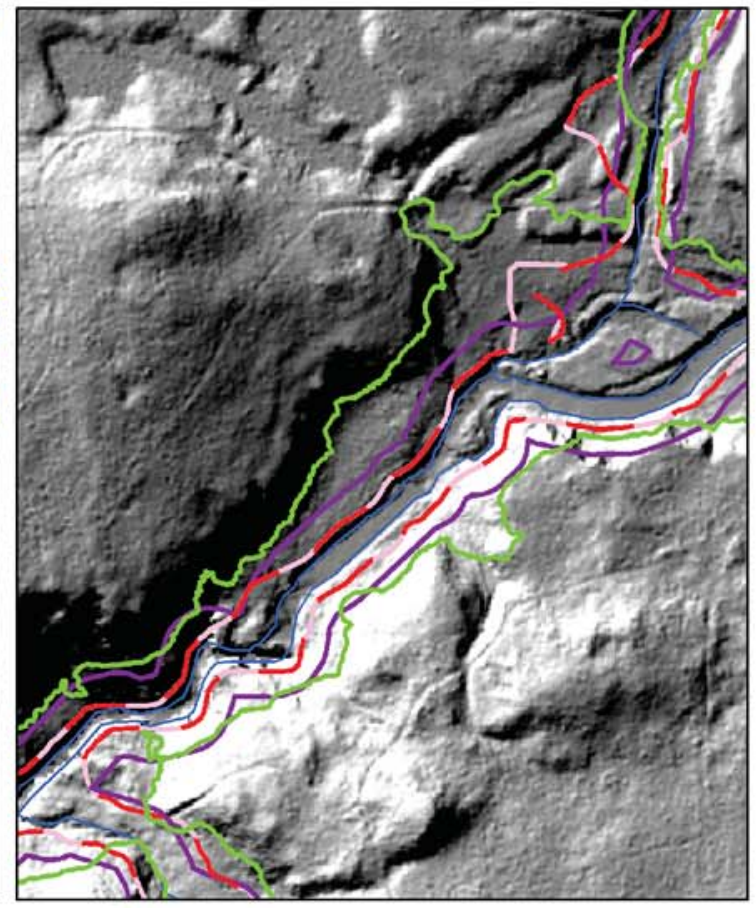

3 Fixed $100 \mathrm{ft}$ buffer

3 Field mapped riparian zone

$\sim$ Rivers and streams

$\begin{array}{lll}0 & 0.05 & 0.1\end{array}$

0.2

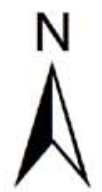

Figure 4.7 - RDBM elevation only, RBDM all input parameters, fixed width buffer, and field mapped riparian zones for the Sturgeon River area. 


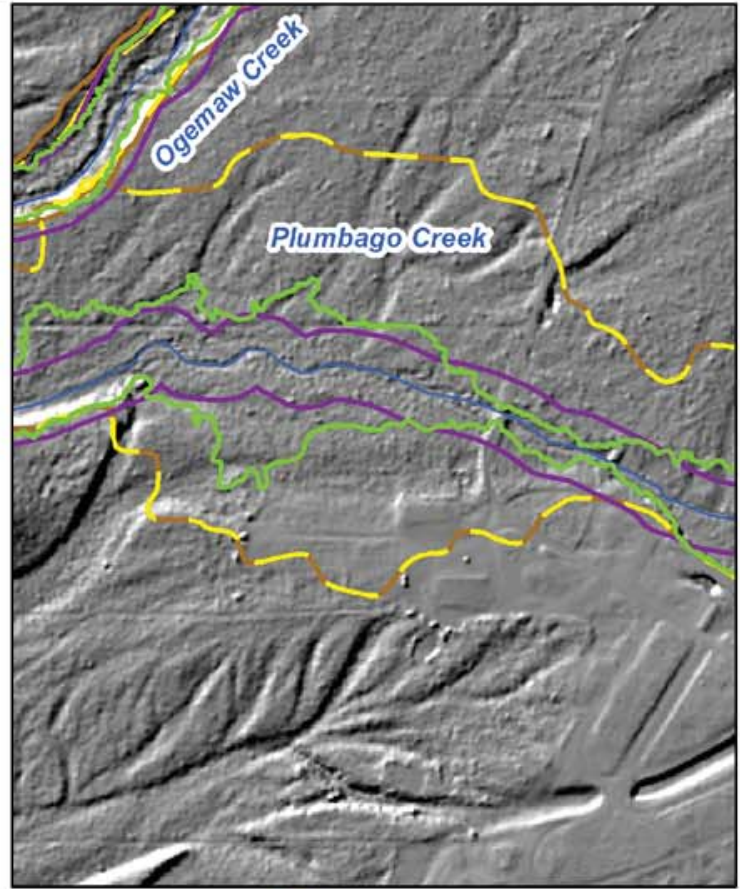

RDBM - 1m, elevation only

3 RDBM - 1 m, complete model

ح RDBM - $0.5 \mathrm{~m}$, elevation only

RDBM - $0.5 \mathrm{~m}$, complete model

$\begin{array}{lll}0 & 0.050 .1 \quad 0.2\end{array}$

Kilometers

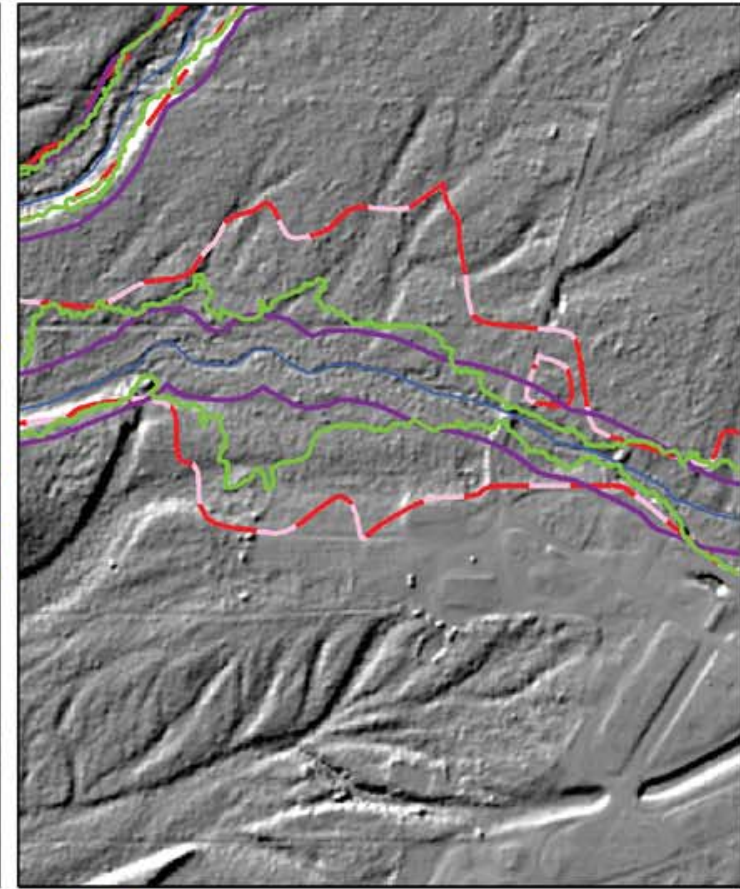

3 Fixed $100 \mathrm{ft}$ buffer

3 Field mapped riparian zone

$\sim$ Rivers and streams

$\begin{array}{llll}0 & 0.05 & 0.1 & 0.2\end{array}$ Miles

Figure 4.8 - RDBM, fixed width buffer, and field mapped riparian zone results for the Plumbago Creek and Ogemaw Creek area. 

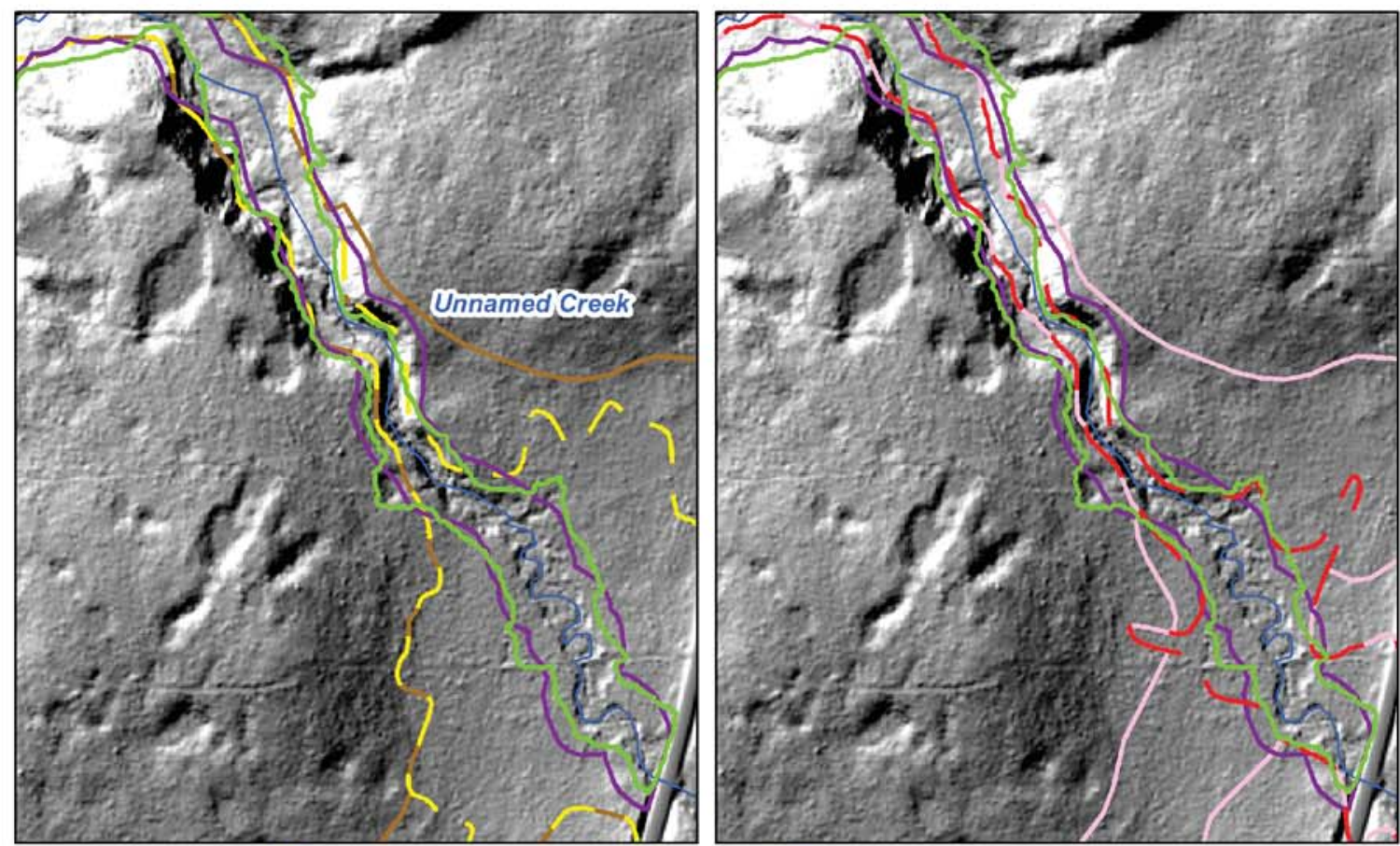

RDBM - 1m, elevation only

3 RDBM - $1 \mathrm{~m}$, complete model

$\sim 3$ RDBM $-0.5 \mathrm{~m}$, elevation only

3 Fixed $100 \mathrm{ft}$ buffer

3 RDBM - $0.5 \mathrm{~m}$, complete model

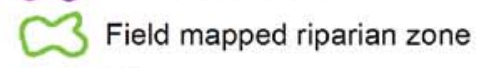

$\sim$ Rivers and streams

0.2

00.050 .1

Kilometers

\section{$\begin{array}{lll}0 & 0.05 & 0.1\end{array}$}

\section{2} Miles

Figure 4.9 - RDBM, fixed width buffer, and field mapped riparian zone results for an unnamed creek south of the Sturgeon River.

In general, the walked riparian zone area most closely followed the RDBM 0.5 meter complete model in terms of total amount of hectares delineated as riparian. However, it should be noted that while the total hectares was roughly equivalent, the actual boundaries between the field mapped and 0.5 meter complete model were not the same. 


\subsection{Discussion}

\subsubsection{Fixed width buffer vs. the RDBM}

Generally, it was found that the fixed width buffer was not adequate for determining the extent of the riparian zone. As Figures 4.7 and 4.8 show, the boundary of the riparian zone is variable and does not consistently remain 100 feet away from the watercourse. To best protect riparian zones, the RDBM is a better determinant of riparian zones and boundaries.

Determining which RDBM boundary best replicates field conditions is a more difficult. Generally, it would be recommended that landowners utilize the 0.5 or 1 meter complete model boundaries. As the complete model takes into account not only the topology but also the soils and wetlands adjacent to rivers and streams, it enables landowners to determine areas that may need further protection in order to preserve stream water quality and delicate hydric soils. Ideally, the 1 meter complete model boundary, which generated the largest riparian buffer, should be used to delineate riparian zones to determine a "conservative" riparian zone. By utilizing a more conservative riparian zone landowners should be able to best protect stream water quality and reduce overflow runoff from logging or other activities taking place on their property.

In addition to the RDBM being capable of generating multiple buffers based on available data, it also should be noted that the model is easy to run with a minimum of effort. This ease of use enables landowners or other users of the model to quickly determine the riparian corridors in a format that can be quickly applied to the field via a hand-held GPS unit. With the model preserving a far more conservative riparian zone and the model being simple and relatively quick to complete, it is highly recommended that landowners consider this model for logging or other activities on their holdings. 


\subsubsection{Potential sources of error and variability}

The RDBM buffer is highly dependent on the quality of the data entered into it. Differences in area between the elevation only and complete RDBM models were due to available wetland and hydric soil data which may not always be accurate and/or consistently mapped. For example, north of the Sturgeon River, much of the gorge area is identified as a Champion Series soil (Figure 1.2) which is classified as a well-drained soil. However, this area during data collection was found to be mucky with occasional vernal pools with an overstory of balsam fir and other woody wetland species. While no attempt was done to identify soil types or assess the soil map's accuracy, it should still be noted the impact this information has on the delineated riparian zones. When the RDBM runs, it inspects the provided feature classes for data on hydric soils and wetlands and, in the case of the complete model, incorporates this data into the final results. If either the soil or wetland feature classes are inaccurate, these inaccuracies are passed on to the final results. Hence the user should take care to try and provide the model with the most accurate data possible. If errors in the associated feature classes are considerable and the user is unable to correct these errors prior to the model being run, it may be best to determine the riparian zone based solely on the elevation values if an accurate, high spatial resolution DEM is available.

Besides potential issues with the available data, the next largest source of potential error is with the field mapped riparian zones. While attempts to reduce data collection bias were made, the field mapped path is highly dependent on the user and the field conditions at the time. There were multiple times where the user was forced to take detours, backtrack, or deviate from the perceived riparian boundary due to inaccessibility. This issue was most prevalent in the area surrounding the Sturgeon River due to its rapid elevation changes, swampy areas, and the gorge. 
Additionally, determining the boundary of a riparian zone can be very difficult to determine in the field. The herbaceous species used to delineate the field mapped boundaries can vary in their locations due to changes in climate or human activity and it can be difficult to determine a precise border between riparian and upland zones. Additionally, while species were identified as being more likely to appear in either riparian or upland areas, due to ground conditions, the flora were not always found in their designated areas. Jack-in-the-pulpit was found in upland areas, usually in areas of small depressions due to micro-topology, and false Solomon's seal was occasionally found along stream banks. This made the delineation between the riparian and upland areas far more arbitrary and up to the data collector to determine the boundary. Digging soil pits and identifying soil types along the riparian corridor may aid in identifying riparian zones, but this would dramatically increase field work and lab work. Overstory tree species, due to their longer presence on the landscape, may be a better indicator of riparian corridors, but only if they have not been greatly impacted by human activity.

\subsection{Conclusions}

While the RDBM is highly dependent on accurate data to provide the best results, it still provides landowners with a better and more accurate riparian zone then the fixed width buffer. To reduce errors, model users should attempt to assess data accuracy and correct issues before the model is run. While the user is ultimately the one to decide which version of the model best suits their goals, it is recommended that the 1 meter, complete model is used to delineate riparian boundaries as it encompasses the greatest amount of area and would better protect steam water quality from runoff related issues. 


\section{CHAPTER 5}

\section{RECOMMENDATIONS FOR THE FORD RESEARCH FOREST}

\subsection{Application of the RBDM on the Ford Research Forest}

As the RDBM does the best job of mapping riparian corridors, it is recommend managers utilize a combination of it with a minimum $30.5 \mathrm{~m}$ (100 ft.) buffer to protect the Ford Research Forest waterways. A minimum buffer of $30.5 \mathrm{~m}$ between harvesting activity and the watercourse is especially critical in the Sturgeon River gorge where there are areas the RBDM does not map the buffer $>30.5 \mathrm{~m}$. While the steep slopes in the Sturgeon River gorge would protect such areas from flooding, overland runoff from logging activities would be better intercepted by the larger buffer and reduce the risk of sediment contamination. Harvesting activities should be limited to winter in order to reduce soil compaction and runoff.

Ideally, the soil maps of the area should be refined. Especially in the Sturgeon River area they are not accurate with numerous inclusions of different soils within a polygon. For example, during field work many muck soils areas were found within the Champion cobbly silt loam, which is classified as well drained. While undertaking a complete soil resurvey is economically infeasible, having a soil scientist complete spot checks for obvious inclusion areas would be useful. As the results of the RBDM model are dependent on accurate soil and wetland maps, investing time into improving the data inputs is justifiable.

\subsection{Suggestions for future remote sensing endeavors on the Ford Research Forest}

Further remote sensing classification research is advisable. The technology of remote sensing is currently undergoing dramatic changes as computer processing times 
and costs continue to decrease. Data acquisition costs are also decreasing particularly with the use of Unmanned Aerial Vehicles (UAV). Dependent on goals and funding several types of imagery should be considered.

\subsubsection{Hyperspectral Remote Sensing}

Ideally, should acquire, analyze and classify hyperspectral imagery of the Ford Research Forest and potentially other Michigan Tech forested properties. This is a project the School should give serious consideration. Utilizing satellite based hyperspectral imagery could reduce image collection costs and building a hyperspectral library would be an excellent project for a Masters or PhD student. Hyperspectral remote sensing does seem to be a key component of the future of remote sensing.

\subsubsection{Reoccurring classifications}

Periodic updating of the forest cover type data should be implemented. This would be far more cost effective than utilizing traditional field methods and provide detailed and synoptic coverage of the area. It is also suggested that future mapping efforts keep imagery acquisition and field accuracy data collection dates as concurrent as possible. The methods detailed in Chapters 2 and 3 did a very good job of classifying the Ford Research Forest, but more concurrent image and field data collection could possibly increase accuracy. Reclassifying the property on a regular basis could be an excellent way of tracking and quantifying land use and land cover changes both for the Ford Center and for the larger landscape as a whole. 


\section{LITERATURE CITED}

Abood, S. A. (2011) Riparian Buffer Delineation Model- RBDM Version 2.3 (Full) Manual. Michigan Technological University, Houghton-Michigan: School of Forest Resources and Environmental Science

Abood, S. A., Maclean, A. L. and Mason, L. A. (2012) 'Modeling Riparian Zones Utilizing DEMS and Flood Height Data', Photogrammetric Engineering \& Remote Sensing, 78(3), pp. 259-269. doi: 10.14358/pers.78.3.259

Anderson, D. (1991) 'Examining prehistoric settlement distribution in eastern North America', Archaeology of Eastern North America, 19pp. 1-22.

Antonarakis, A. S., Richards, K. S. and Brasington, J. (2008) 'Object-based land cover classification using airborne LiDAR', Remote Sensing of Environment, 112(6), pp. 29882998. doi: 10.1016/j.rse.2008.02.004

Aunan, T., Palik, B.J., and Verry, E.S.(2005) 'A GIS approach for delineating variable width buffers based on hydrological function', Research Report 0105, Minnesota Forest Resources Council, Grand Rapids, MN. Print.

Barnes, B. V., Zak, D. R., Denton, S. R. and Spurr, S. H. (1998) Forest Ecology. Edited by Ellen Schatz. 4th edn. USA: John Wiley \& Sons Inc. Print.

Barnes, B. V. V. and Wagner, W. H. (1981) Michigan trees: a guide to the trees of Michigan and the Great Lakes region. Ann Arbor: University of Michigan Press. Print.

Benz, U. C., Hofmann, P., Willhauck, G., Lingenfelder, I. and Heynen, M. (2004) 'Multiresolution, object-oriented fuzzy analysis of remote sensing data for GIS-ready information', ISPRS Journal of Photogrammetry and Remote Sensing, 58(3-4), pp. 239-258. doi: $10.1016 /$ j.isprsjprs.2003.10.002

Brosofske, K. D., Chen, J., Naiman, R. J. and Franklin, J. F. (1997) 'Harvesting effects on microclimatic gradients from small streams to uplands in western Washington', Ecological Applications, 7(4), pp. 1188-1200. doi: 10.1890/1051-0761(1997)007[1188:heomgf]2.0.co;2

Bryant, E, Dodge, A.G., and Warren, S.D, (1980) 'Landsat for practical forest type mapping - A test case', Photogrammetric Engineering and Remote Sensing, 46(12), pp. 1575-1584.

Burger, T. L. and Kotar, J. (2003) A Guide to Forest Communities and Habitat Types of Michigan. Madison, WI: Department of Forest Ecology and Management, University of Wisconsin-Madison. Print.

Chavez, P.S. (1988) 'An Improved Dark-Object Subtraction technique for atmospheric scattering correction of multispectral data', Remote Sensing of Environment, 24(3), pp. 459479 doi: 10.1016/0034-4257(88)90019-3

Clifton, J. A., Cornell, G. L. and McClurken, J. M. (1986) People of the Three Fires: The Ottawa, Potawatomi, and Ojibway of Michigan. Grand Rapids, MI: Michigan Indian Press, Grand Rapids Inter-Tribal Council. Print. 
Congalton, R. G. and Green, K. (2008) Assessing the Accuracy of Remotely Sensed Data: Principles and Practices. 2nd edn. Boca Raton: CRC Press/Taylor \& Francis

Dickmann, D. I. and Leefers, L. A. (2003) The Forests of Michigan. Ann Arbor: University of Michigan Press/Regional. Print.

Duda, R.O., Hart, P.E., and Stork, D.G. (2001) Pattern Classification, New York: John Wiley \& Sons. Print.

Ewing, H. A. (2002) 'The Influence of Substrate on Vegetation History and Ecosystem Development', Ecology, 83(10), pp. 2766-2781. doi: 10.2307/3072014

Fullerton, D. S. (1986) 'Stratigraphy and correlation of glacial deposits from Indiana to New York and New Jersey', Quaternary Science Reviews, 5pp. 23-37. doi: 10.1016/02773791(86)90171-X

Gaveau, D.L.A., and Hill, R.A. (2003) 'Quantifying canopy height underestimation by laser pulse penetration in small-footpring airborne laser scanning data', Canadian Journal of Remote Sensing, 29(5), pp. 605-657

Geneletti, D. and Gorte, B. G. H. (2003) 'A method for object-oriented land cover classification combining Landsat TM data and aerial photographs', International Journal of Remote Sensing, 24(6), pp. 1273-1286. doi: 10.1080/01431160210144499

Hill, R.A., Wilson, A.K., George, M., and Hinsley, S.A. (2010) 'Mapping tree species in temperate deciduous woodland using time-series multi-spectral data', Applied Vegetation Science, 13(1), pp. 86-99

Holmes, K.L., and P.C. Goebel. (2011), 'A functional approach to riparian area delineation using geospatial methods', Journal of Forestry. 109, pp. 233-241

Ilhardt, B.L., Verry, E.S., and Palik, B.J. (2000) 'Defining Riparian Areas', Riparian Management in Forests of the Continental Eastern United States. (Verry, E.S., Hornbeck, J.W., and Dolloff, C.A., editors). Lewis Publishers, New York, NY, pp. 23-42

Jensen, John R. (2004) Introductory Digital Image Processing: A Remote Sensing Perspective. 3rd ed. Upper Saddle River, N.J.: Prentice Hall. Print.

Johansen, K., Coops, N. C., Gergel, S. E. and Stange, Y. (2007) 'Application of high spatial resolution satellite imagery for riparian and forest ecosystem classification', Remote Sensing of Environment, 110(1), pp. 29-44. doi: 10.1016/j.rse.2007.02.014

Johnson, W. H. (1986) 'Stratigraphy and correlation of the glacial deposits of the Lake Michigan lobe prior to 14 ka BP', Quaternary Science Reviews, 5pp. 17-22. doi: 10.1016/s0277-3791(86)80005-1

Johnson, W. H., Hansel, A. K., Bettis, E. A., Karrow, P. F., Larson, G. J., Lowell, T. V. and Schneider, A. F. (1997) 'Late Quaternary Temporal and Event Classifications, Great Lakes Region, North America', Quaternary Research, 47(1), pp. 1-12. doi: 10.1006/qres.1996.1870 
Karrow, P. F. (1984) 'Quaternary stratigraphy and history, Great Lakes-St. Lawrence region', Quaternary Stratigraphy of Canada - A Canadian Contribution to IGCP Project 24, (84-10), pp. 137-153. doi: 10.4095/119765

Karrow, P. F., Dreimanis, A. and Barnett, P. J. (2000) 'A Proposed Diachronic Revision of Late Quaternary Time-Stratigraphic Classification in the Eastern and Northern Great Lakes Area',Quaternary Research, 54(1), pp. 1-12. doi: 10.1006/qres.2000.2144

Key, T., Warner, T. A., McGraw, J. B. and Fajvan, M. A. (2001) 'A Comparison of Multispectral and Multitemporal Information in High Spatial Resolution Imagery for Classification of Individual Tree Species in a Temperate Hardwood Forest', Remote Sensing of Environment, 75(1), pp. 100-112. doi: 10.1016/s0034-4257(00)00159-0

Landis, R. J. and Koch, G. G. (1977) 'The Measurement of Observer Agreement for Categorical Data', Biometrics, 33(1), pp. 159-174. doi: 10.2307/2529310

Larson, G. and Schaetzl, R. (2001) 'Origin and Evolution of the Great Lakes', Journal of Great Lakes Research, 27(4), pp. 518-546. doi: 10.1016/s0380-1330(01)70665-x

Leckie, D., Gougeon, F., Walsworth, N. and Paradine, D. (2003) 'Stand delineation and composition estimation using semi-automated individual tree crown analysis', Remote Sensing of Environment, 85(3), pp. 355-369. doi: 10.1016/s0034-4257(03)00013-0

Lee, P., Smith, C. and Boutin, S. (2004) 'Quantitative review of riparian buffer width guidelines from Canada and the United States', Journal of Environmental Management, 70pp. 165-180.

Lewis, CT, and Short, C. (1956) A Latin Dictionary. England: Oxford University Press. Print.

Maclean, A.L. and Cleland, D.T. (2003) The use of geostatistics to determine the spatial extent of historical fires as an aid in understanding fire regimes for northern lower Michigan in Fire, Fuel Treatments and Ecological Restoration: Conference Proceedings. Rocky Mountain Research Stations, Proceedings RMRS-P-29. pp 289-300.

MacNally, R., Molyneux, G., Thomson, J. R., Lake, P. S. and Read, J. (2007) 'Variation in widths of riparian-zone vegetation of higher-elevation streams and implications for conservation management', Plant Ecology, 198(1), pp. 89-100. doi: 10.1007/s11258-0079387-5

Mann, C. C. (2005) 1491: New revelations of the Americas before Columbus. 6th edn. New York: Knopf Doubleday Publishing Group. Print.

Mason, L.A. GIS Modeling of Riparian Zones Utilizing Digital Elevation Models and Flood Height Data. M.S. Thesis. Houghton: Michigan Technological University, 2007. Print.

Mathieu, R., Freeman, C. and Aryal, J. (2007) 'Mapping private gardens in urban areas using object-oriented techniques and very high-resolution satellite imagery', Landscape and Urban Planning, 81(3), pp. 179-192. doi: 10.1016/j.landurbplan.2006.11.009

Meinel, G. and Neubert, M. (2004) 'A comparison of segmentation programs for high resolution remote sensing data', International Archives of Photogrammetry and Remote Sensing, 35, pp. 1097-1105. 
Mickelson, J.G., Civco, D.L., and Silander, J.A. (1998) 'Delineating forest canopy species in the northeastern United States using multi-temporal TM imagery', Photogrammetric Engineering and Remote Sensing, 64(9), pp. 891-904.

Michigan Department of Natural Resources (2009) Sustainable soil and water quality practices on forest land. Available at:

http://www.michigan.gov/documents/dnr/IC4011_SustainableSoilAndWaterQualityPractices OnForestLand_268417_7.pdf

Miller, G. H., Wolfe, A. P., Briner, J. P., Sauer, P. E. and Nesje, A. (2005) 'Holocene glaciation and climate evolution of Baffin Island, Arctic Canada', Quaternary Science Reviews, 24(14-15), pp. 1703-1721. doi: 10.1016/j.quascirev.2004.06.021

Naiman, R. J., Décamps, H. and McClain, M. E. (2005) Riparia: Ecology, Conservation, and Management of Streamside Communities. United Kingdom: Academic Press Inc. Print.

National Research Council (2002) Riparian Areas: Functions and Strategies for Management. Washington, D.C.: National Academies Press. Print.

Natural Resources Conservation Service (2014) USDA Geospatial Data Gateway. Available at: https://gdg.sc.egov.usda.gov/ (Accessed: 29 May 2015)

Nelson, R.F., Latty, R.S., and Mott, G. (1984) 'Classifying Northern forests using thematic mapper simulator data', Photogrammetric Engineering and Remote Sensing, 50(5), pp.607617.

Oetter, D.R., Cohen, W.B., Berterretche, M., Maiersperger, T.K. and Kennedy, R.E. (2001) 'Land cover mapping in an agricultural setting using multiseasonal Thematic Mapper data', Remote Sensing of the Environment, 76(1), pp. 139-155

Olthof, I, Pouliot, D, Latifovic, R, and Chen WJ. (2008) 'Recent (1986-2006) vegetationspecific NDVI trends in northern Canada from satellite data', Arctic, 61(4), pp. 381-394.

Platt, R. V. and Rapoza, L. (2008) 'An Evaluation of an Object-Oriented Paradigm for Land Use/Land Cover Classification*', The Professional Geographer, 60(1), pp. 87-100. doi: $10.1080 / 00330120701724152$

Schriever, J. and Congalton, R. (1995) 'Evaluating seasonal variability as an aid to covertype mapping from Landsat Thematic Mapper data in the Northeast', Photogrammetric Engineering and Remote Sensing, 61(3), pp. 321-327.

Seymour, R. S., White, A. S. and deMaynadier, P. G. (2002) 'Natural disturbance regimes in northeastern North America-evaluating silvicultural systems using natural scales and frequencies', Forest Ecology and Management, 155(1-3), pp. 357-367. doi: 10.1016/s03781127(01)00572-2

Skally, C. and Sagor, E. (2001) 'Comparing riparian management zones to riparian areas in Minnesota: A pilot study', Research Report RR-1001, Minnesota Forest Resources Council, St. Paul, MN, pp. 11.

Stephenson, N. L. (1990) 'Climatic Control of Vegetation Distribution: The Role of the Water Balance', The American Naturalist, 135(5), pp. 649-670. doi: 10.1086/285067 
US Department of Agriculture Forest Service (2004) Forest Service Manual, Title 2500. Section 2526.05 edn. Washington, DC: Watershed and Air Management

USGS (2014) Landsat Missions Timeline. Available at:

http://landsat.usgs.gov/about_mission_history.php (Accessed: 13 June 2015)

Verry, E. S., Dolloff, C. A. and Manning, M. E. (2004) 'Riparian ecotone: A functional definition and delineation for resource assessment', Water, Air, and Soil Pollution: Forcus, 4pp. 67-94.

Weih, C and Riggan, N.D. (2010) 'Object-based classification vs. pixel-based classification: Comparative importance of multi-resolution imagery', The International Archives of the Photogrammetry, Remote Sensing, and Spatial Information Sciences, XXXVIII-4/C7

Whitney, G. G. (1986) 'Relation of Michigan's Presettlement Pine Forests to Substrate and Disturbance History', Ecology, 67(6), pp. 1548-1559. doi: 10.2307/1939085

Wolter, P., Mladenoff, D., Host, G. and Crow, T. (1995) 'Improved forest classification in the Northern lake-states using multitemporal Landsat Imagery', Photogrammetric Engineering and Remote Sensing, 61(9), pp. 1129-1143 


\section{APPENDIX A}

\begin{tabular}{|c|c|c|c|c|}
\hline ID Number & Classified As & Field Checked & X-coordinate & Y-coordinate \\
\hline 1 & Aspen & Conifer & 384401.125 & 5167724 \\
\hline 2 & Aspen & Aspen & 382897 & 5169101 \\
\hline 3 & Aspen & Aspen & 385235.8125 & 5167569 \\
\hline 4 & Aspen & Aspen & 383787.9063 & 5168956 \\
\hline 5 & Aspen & Aspen & 385329.375 & 5167946 \\
\hline 6 & Aspen & Deciduous & 387645.9375 & 5166964 \\
\hline 7 & Aspen & Aspen & 383197.75 & 5169782 \\
\hline 8 & Aspen & Aspen & 385092 & 5168080.5 \\
\hline 9 & Aspen & Aspen & 383369.375 & 5169108 \\
\hline 10 & Aspen & Aspen & 383372.375 & 5169153 \\
\hline 11 & Aspen & Aspen & 383292.3438 & 5169161 \\
\hline 12 & Aspen & Deciduous & 387812.125 & 5167194.5 \\
\hline 13 & Aspen & Aspen & 382900.1875 & 5169657.5 \\
\hline 14 & Aspen & Aspen & 383061.6875 & 5170306 \\
\hline 15 & Aspen & Aspen & 387836.25 & 5165295 \\
\hline 16 & Aspen & Aspen & 383188.8438 & 5169189 \\
\hline 17 & Aspen & Deciduous & 387279.4375 & 5164208.5 \\
\hline 18 & Aspen & Aspen & 387751.0313 & 5166439.5 \\
\hline 19 & Aspen & Aspen & 384818.625 & 5166165 \\
\hline 20 & Aspen & Aspen & 385253.9375 & 5167926 \\
\hline 21 & Aspen & Deciduous & 386637.9688 & 5163753 \\
\hline 22 & Aspen & Deciduous & 386098.9688 & 5163453 \\
\hline 23 & Aspen & Deciduous & 387356.5313 & 5165793.5 \\
\hline 24 & Aspen & Aspen & 382699.7188 & 5170512 \\
\hline 25 & Aspen & Aspen & 387839.6875 & 5165263 \\
\hline 26 & Aspen & Aspen & 382699.9375 & 5170140.5 \\
\hline 27 & Aspen & Aspen & 383017.625 & 5169651.5 \\
\hline 28 & Aspen & Aspen & 382959.9375 & 5169199 \\
\hline 29 & Aspen & Deciduous & 383936.6563 & 5168962 \\
\hline 30 & Aspen & Aspen & 382830.25 & 5170211.5 \\
\hline 31 & Aspen & Aspen & 383387.3125 & 5169200 \\
\hline 32 & Aspen & Aspen & 383814.8125 & 5168625.5 \\
\hline 33 & Aspen & Aspen & 383031.4375 & 5170286.5 \\
\hline 34 & Aspen & Aspen & 382979.7188 & 5169707 \\
\hline 35 & Aspen & Deciduous & 386753.25 & 5165824.5 \\
\hline 36 & Aspen & Aspen & 383343.9688 & 5169261.5 \\
\hline 37 & Aspen & Aspen & 382984.125 & 5170040.5 \\
\hline 38 & Aspen & Aspen & 383770.8438 & 5169001.5 \\
\hline 39 & Aspen & Aspen & 385241.0625 & 5167524 \\
\hline 40 & Aspen & Aspen & 382588.4688 & 5170860 \\
\hline
\end{tabular}




\begin{tabular}{|c|c|c|c|c|}
\hline ID Number & Classified As & Field Checked & X-coordinate & Y-coordinate \\
\hline 41 & Aspen & Aspen & 385498.25 & 5167810.5 \\
\hline 42 & Aspen & Aspen & 385078.1563 & 5166277 \\
\hline 43 & Aspen & Aspen & 383085.25 & 5169388.5 \\
\hline 44 & Aspen & Aspen & 383128.3125 & 5169779.5 \\
\hline 45 & Aspen & Aspen & 383251.9375 & 5169296.5 \\
\hline 46 & Aspen & Deciduous & 387835.7813 & 5166935.5 \\
\hline 47 & Aspen & Aspen & 382527.4375 & 5170812.5 \\
\hline 48 & Aspen & Aspen & 387772.2813 & 5166424 \\
\hline 49 & Aspen & Aspen & 382585.1563 & 5170671.5 \\
\hline 50 & Aspen & Aspen & 383486.9063 & 5169203.5 \\
\hline 51 & Conifer & Conifer & 384467.7188 & 5167574.5 \\
\hline 52 & Conifer & Woody Wetlands & 381854.5 & 5164741 \\
\hline 53 & Conifer & Open & 384338.75 & 5166949 \\
\hline 54 & Conifer & Conifer & 383908.4688 & 5168330 \\
\hline 55 & Conifer & Woody Wetlands & 382376.7188 & 5165065.5 \\
\hline 56 & Conifer & Jack Pine & 384198.0938 & 5166041 \\
\hline 57 & Conifer & Aspen & 384789.3125 & 5166100 \\
\hline 58 & Conifer & Woody Wetlands & 382083.5 & 5164860.5 \\
\hline 59 & Conifer & Woody Wetlands & 382410.1875 & 5165173 \\
\hline 60 & Conifer & Conifer & 383636.875 & 5170186.5 \\
\hline 61 & Conifer & Conifer & 384938.0313 & 5167996 \\
\hline 62 & Conifer & $X X X X$ & 381116.875 & 5165332 \\
\hline 63 & Conifer & $x X X X$ & 381399.0313 & 5164602 \\
\hline 64 & Conifer & Conifer & 384717.875 & 5167791 \\
\hline 65 & Conifer & Conifer & 384818.7188 & 5167668 \\
\hline 66 & Conifer & $X X X X$ & 383577.875 & 5164501.5 \\
\hline 67 & Conifer & Woody Wetlands & 382007.625 & 5164827 \\
\hline 68 & Conifer & Conifer & 384236.6563 & 5167853.5 \\
\hline 69 & Conifer & Conifer & 383850.0625 & 5169649.5 \\
\hline 70 & Conifer & $X X X X$ & 383691.0938 & 5164940.5 \\
\hline 71 & Conifer & Conifer & 384683.75 & 5166073.5 \\
\hline 72 & Conifer & Conifer & 384139.9375 & 5167941.5 \\
\hline 73 & Conifer & Jack Pine & 383954.6875 & 5167443 \\
\hline 74 & Conifer & $x X X X$ & 383472.5625 & 5164884.5 \\
\hline 75 & Conifer & Conifer & 383923.75 & 5167889.5 \\
\hline 76 & Conifer & Conifer & 385047.9688 & 5168206 \\
\hline 77 & Conifer & Woody Wetlands & 384610.8438 & 5166930.5 \\
\hline 78 & Conifer & $X X X X$ & 382497.7813 & 5164658.5 \\
\hline 79 & Conifer & Conifer & 384459.125 & 5168175 \\
\hline 80 & Conifer & Conifer & 384001.375 & 5169024.5 \\
\hline 81 & Conifer & $X X X X$ & 384254.8125 & 5164621 \\
\hline 82 & Conifer & Conifer & 384719.9375 & 5168120 \\
\hline 83 & Conifer & Aspen & 384426.6875 & 5165672 \\
\hline 84 & Conifer & Conifer & 384166.6875 & 5167985 \\
\hline 85 & Conifer & Aspen & 384356.5313 & 5165563 \\
\hline
\end{tabular}




\begin{tabular}{|c|c|c|c|c|}
\hline ID Number & Classified As & Field Checked & X-coordinate & Y-coordinate \\
\hline 86 & Conifer & Conifer & 383918 & 5168046.5 \\
\hline 87 & Conifer & Conifer & 384100.25 & 5168217.5 \\
\hline 88 & Conifer & Conifer & 384876.1563 & 5168129.5 \\
\hline 89 & Conifer & Conifer & 384642.2813 & 5167648.5 \\
\hline 90 & Conifer & Conifer & 383862.4063 & 5169319 \\
\hline 91 & Conifer & Conifer & 384785.1875 & 5168002.5 \\
\hline 92 & Conifer & Conifer & 384060.4375 & 5168029 \\
\hline 93 & Conifer & Conifer & 384502.2813 & 5167460 \\
\hline 94 & Conifer & $X X X X$ & 383245.6563 & 5165393.5 \\
\hline 95 & Conifer & $X X X X$ & 380870.0938 & 5164823 \\
\hline 96 & Conifer & Woody Wetlands & 385410.4688 & 5168236 \\
\hline 97 & Conifer & Mixed & 384438.8438 & 5165233.5 \\
\hline 98 & Conifer & Jack Pine & 383996.5 & 5166639 \\
\hline 99 & Conifer & Conifer & 383705.75 & 5169368.5 \\
\hline 100 & Conifer & Conifer & 384792.6563 & 5168185 \\
\hline 101 & Deciduous & Deciduous & 385713.9375 & 5163993 \\
\hline 102 & Deciduous & Aspen & 383762.2188 & 5168906.5 \\
\hline 103 & Deciduous & Deciduous & 387166.0938 & 5164848.5 \\
\hline 104 & Deciduous & Deciduous & 386691.4688 & 5164863 \\
\hline 105 & Deciduous & Deciduous & 387235.3438 & 5163919.5 \\
\hline 106 & Deciduous & Deciduous & 387346.625 & 5164745 \\
\hline 107 & Deciduous & Deciduous & 386781.8125 & 5163850.5 \\
\hline 108 & Deciduous & Conifer & 384492.5938 & 5167420 \\
\hline 109 & Deciduous & Deciduous & 382573.6875 & 5168988 \\
\hline 110 & Deciduous & Woody Wetlands & 384976.3125 & 5165788 \\
\hline 111 & Deciduous & Deciduous & 387496.25 & 5166943 \\
\hline 112 & Deciduous & Deciduous & 386505 & 5165694 \\
\hline 113 & Deciduous & Deciduous & 387327.4375 & 5162667.5 \\
\hline 114 & Deciduous & Deciduous & 382506.1563 & 5170658.5 \\
\hline 115 & Deciduous & Deciduous & 387429.9375 & 5163563.5 \\
\hline 116 & Deciduous & Deciduous & 386408.0625 & 5167280.5 \\
\hline 117 & Deciduous & Deciduous & 387844.2188 & 5167614.5 \\
\hline 118 & Deciduous & Deciduous & 386324.8438 & 5166371.5 \\
\hline 119 & Deciduous & Deciduous & 386735.2813 & 5165611 \\
\hline 120 & Deciduous & Woody Wetlands & 385804.4688 & 5165508.5 \\
\hline 121 & Deciduous & Deciduous & 386089.875 & 5166643 \\
\hline 122 & Deciduous & Deciduous & 387790.9688 & 5163343.5 \\
\hline 123 & Deciduous & Deciduous & 387557.1875 & 5167402 \\
\hline 124 & Deciduous & Deciduous & 386330.8125 & 5162519.5 \\
\hline 125 & Deciduous & Deciduous & 386066.2188 & 5166989.5 \\
\hline 126 & Deciduous & Deciduous & 386648.8438 & 5162396.5 \\
\hline 127 & Deciduous & Deciduous & 386625.0313 & 5162932.5 \\
\hline 128 & Deciduous & Conifer & 384806.9063 & 5167506 \\
\hline 129 & Deciduous & Deciduous & 387121.8438 & 5164095.5 \\
\hline 130 & Deciduous & Aspen & 385105.4063 & 5167985.5 \\
\hline 131 & Deciduous & Deciduous & 385935 & 5163192.5 \\
\hline
\end{tabular}




\begin{tabular}{|c|c|c|c|c|}
\hline ID Number & Classified As & Field Checked & X-coordinate & Y-coordinate \\
\hline 132 & Deciduous & Deciduous & 387042.2188 & 5164911.5 \\
\hline 133 & Deciduous & Deciduous & 385643.0938 & 5166311 \\
\hline 134 & Deciduous & Deciduous & 386576.375 & 5165340 \\
\hline 135 & Deciduous & Deciduous & 386603.375 & 5165361.5 \\
\hline 136 & Deciduous & Deciduous & 386982.3438 & 5165360 \\
\hline 137 & Deciduous & Deciduous & 385693.0313 & 5163534 \\
\hline 138 & Deciduous & Deciduous & 386859.9375 & 5163351.5 \\
\hline 139 & Deciduous & Deciduous & 386613.75 & 5162645.5 \\
\hline 140 & Deciduous & Mixed & 386974.25 & 5163917 \\
\hline 141 & Deciduous & Deciduous & 385736.0938 & 5163714.5 \\
\hline 142 & Deciduous & Deciduous & 386775 & 5163497 \\
\hline 143 & Deciduous & Deciduous & 387337.6563 & 5164223 \\
\hline 144 & Deciduous & Deciduous & 387026.0625 & 5164617.5 \\
\hline 145 & Deciduous & Mixed & 384827.4375 & 5168493 \\
\hline 146 & Deciduous & Deciduous & 387027.9688 & 5163626 \\
\hline 147 & Deciduous & Deciduous & 386741.5 & 5165036 \\
\hline 148 & Deciduous & Deciduous & 386444.0938 & 5162950 \\
\hline 149 & Deciduous & Deciduous & 382641.0938 & 5169171.5 \\
\hline 150 & Deciduous & Deciduous & 386885.75 & 5162419.5 \\
\hline 151 & Jack Pine & Jack Pine & 384229.3125 & 5166184.5 \\
\hline 152 & Jack Pine & Jack Pine & 382673.9063 & 5166281.5 \\
\hline 153 & Jack Pine & Jack Pine & 381740.625 & 5166254 \\
\hline 154 & Jack Pine & Jack Pine & 383363.125 & 5165546 \\
\hline 155 & Jack Pine & Jack Pine & 382987.9063 & 5167127 \\
\hline 156 & Jack Pine & Jack Pine & 383715.5938 & 5167522 \\
\hline 157 & Jack Pine & Jack Pine & 381076.5 & 5167018 \\
\hline 158 & Jack Pine & Jack Pine & 380781.6563 & 5165887.5 \\
\hline 159 & Jack Pine & Jack Pine & 383380.2188 & 5166427 \\
\hline 160 & Jack Pine & Woody Wetlands & 382291.2813 & 5165104 \\
\hline 161 & Jack Pine & Jack Pine & 383170.5938 & 5165561.5 \\
\hline 162 & Jack Pine & Jack Pine & 382388.0938 & 5166668 \\
\hline 163 & Jack Pine & $X X X X$ & 383803.1875 & 5164491 \\
\hline 164 & Jack Pine & Jack Pine & 381214.875 & 5166671 \\
\hline 165 & Jack Pine & Conifer & 383653.1563 & 5165909 \\
\hline 166 & Jack Pine & Jack Pine & 382277 & 5167057 \\
\hline 167 & Jack Pine & Jack Pine & 382870.5 & 5166953.5 \\
\hline 168 & Jack Pine & Jack Pine & 382295.3438 & 5167301 \\
\hline 169 & Jack Pine & Jack Pine & 382854.8438 & 5167407.5 \\
\hline 170 & Jack Pine & Jack Pine & 381277.125 & 5165997.5 \\
\hline 171 & Jack Pine & $X X X X$ & 381260.0625 & 5165491 \\
\hline 172 & Jack Pine & Jack Pine & 381002.4063 & 5166679 \\
\hline 173 & Jack Pine & Jack Pine & 381743.2188 & 5167402.5 \\
\hline 174 & Jack Pine & Jack Pine & 382039.0938 & 5166755 \\
\hline 175 & Jack Pine & Jack Pine & 382932.5 & 5165936.5 \\
\hline 176 & Jack Pine & Jack Pine & 381156.3438 & 5167587.5 \\
\hline 177 & Jack Pine & Jack Pine & 381498.1563 & 5167399.5 \\
\hline
\end{tabular}




\begin{tabular}{|c|c|c|c|c|}
\hline ID Number & Classified As & Field Checked & X-coordinate & Y-coordinate \\
\hline 178 & Jack Pine & Jack Pine & 381570.5938 & 5166218 \\
\hline 179 & Jack Pine & Jack Pine & 382855.4063 & 5166021.5 \\
\hline 180 & Jack Pine & Jack Pine & 381962.7188 & 5166262.5 \\
\hline 181 & Jack Pine & Jack Pine & 381908.1563 & 5166371.5 \\
\hline 182 & Jack Pine & Jack Pine & 381508.5938 & 5166384.5 \\
\hline 183 & Jack Pine & Jack Pine & 382415.2188 & 5165621.5 \\
\hline 184 & Jack Pine & Jack Pine & 382625.3125 & 5166272.5 \\
\hline 185 & Jack Pine & Jack Pine & 384040.2813 & 5165528.5 \\
\hline 186 & Jack Pine & Jack Pine & 383990.9375 & 5165717.5 \\
\hline 187 & Jack Pine & Woody Wetlands & 382010.5 & 5165059.5 \\
\hline 188 & Jack Pine & Jack Pine & 383775.5625 & 5167069 \\
\hline 189 & Jack Pine & Jack Pine & 382494.9063 & 5167033.5 \\
\hline 190 & Jack Pine & Jack Pine & 381932.375 & 5166277.5 \\
\hline 191 & Jack Pine & Open & 382715.1563 & 5166095 \\
\hline 192 & Jack Pine & Jack Pine & 381718.0313 & 5167611.5 \\
\hline 193 & Jack Pine & $X X X X$ & 382095.1563 & 5164436 \\
\hline 194 & Jack Pine & Jack Pine & 381898.5 & 5167222 \\
\hline 195 & Jack Pine & Jack Pine & 383675.7188 & 5165625.5 \\
\hline 196 & Jack Pine & Jack Pine & 382889.0313 & 5167181 \\
\hline 197 & Jack Pine & Woody Wetlands & 382407.1563 & 5165213 \\
\hline 198 & Jack Pine & Jack Pine & 382686.0938 & 5168002 \\
\hline 199 & Jack Pine & Jack Pine & 383275.1563 & 5165538.5 \\
\hline 200 & Jack Pine & Jack Pine & 382555.9063 & 5168357.5 \\
\hline 201 & Mixed & Mixed & 383600.7813 & 5170529.5 \\
\hline 202 & Mixed & Open & 387328.4688 & 5165410 \\
\hline 203 & Mixed & Mixed & 383241.4375 & 5170467 \\
\hline 204 & Mixed & Mixed & 387541.2813 & 5162617.5 \\
\hline 205 & Mixed & Mixed & 386374.9375 & 5165884 \\
\hline 206 & Mixed & Mixed & 387431.7188 & 5166596 \\
\hline 207 & Mixed & Deciduous & 385583.1875 & 5166738.5 \\
\hline 208 & Mixed & Mixed & 387259.1563 & 5163669 \\
\hline 209 & Mixed & Woody Wetlands & 385441.125 & 5168234 \\
\hline 210 & Mixed & Mixed & 386434.7188 & 5166095 \\
\hline 211 & Mixed & Mixed & 387003.7813 & 5166490 \\
\hline 212 & Mixed & Mixed & 383419.2188 & 5170336.5 \\
\hline 213 & Mixed & Mixed & 383522.7813 & 5170086.5 \\
\hline 214 & Mixed & Mixed & 385733 & 5166663.5 \\
\hline 215 & Mixed & Mixed & 387142.4063 & 5166757.5 \\
\hline 216 & Mixed & Woody Wetlands & 385508.5313 & 5168164.5 \\
\hline 217 & Mixed & Woody Wetlands & 387117.3438 & 5164464.5 \\
\hline 218 & Mixed & Woody Wetlands & 387397.125 & 5165034.5 \\
\hline 219 & Mixed & Deciduous & 385566.1563 & 5167359 \\
\hline 220 & Mixed & Deciduous & 386435.0625 & 5167359 \\
\hline 221 & Mixed & Mixed & 387149.8125 & 5163080 \\
\hline 222 & Mixed & Mixed & 386582.625 & 5167660.5 \\
\hline 223 & Mixed & Mixed & 387406.75 & 5163159 \\
\hline
\end{tabular}




\begin{tabular}{|c|c|c|c|c|}
\hline ID Number & Classified As & Field Checked & X-coordinate & Y-coordinate \\
\hline 224 & Mixed & Open & 387326.75 & 5165402.5 \\
\hline 225 & Mixed & Mixed & 387090.8125 & 5166812.5 \\
\hline 226 & Mixed & Mixed & 387202.5313 & 5164375.5 \\
\hline 227 & Mixed & Mixed & 387074.625 & 5165854.5 \\
\hline 228 & Mixed & Woody Wetlands & 387134.0625 & 5164420.5 \\
\hline 229 & Mixed & Mixed & 385225.9688 & 5168392 \\
\hline 230 & Mixed & Mixed & 385174.75 & 5168370 \\
\hline 231 & Mixed & Mixed & 385214.5313 & 5166679 \\
\hline 232 & Mixed & Mixed & 386650.375 & 5166127.5 \\
\hline 233 & Mixed & Woody Wetlands & 385602.75 & 5166797.5 \\
\hline 234 & Mixed & Mixed & 386465.7813 & 5166171 \\
\hline 235 & Mixed & Mixed & 385487.7188 & 5168266 \\
\hline 236 & Mixed & Mixed & 387113.6875 & 5166848.5 \\
\hline 237 & Mixed & Woody Wetlands & 385476.125 & 5168159 \\
\hline 238 & Mixed & Mixed & 385197.5 & 5166434 \\
\hline 239 & Mixed & Deciduous & 387192.0313 & 5166165 \\
\hline 240 & Mixed & Mixed & 386947.875 & 5166511.5 \\
\hline 241 & Mixed & Mixed & 387382.0625 & 5166454 \\
\hline 242 & Mixed & Woody Wetlands & 387035 & 5164285.5 \\
\hline 243 & Mixed & Mixed & 387158.6875 & 5163101.5 \\
\hline 244 & Mixed & Mixed & 386786 & 5165903.5 \\
\hline 245 & Mixed & Woody Wetlands & 387502.2813 & 5164536.5 \\
\hline 246 & Mixed & Mixed & 383645.25 & 5170850 \\
\hline 247 & Mixed & Mixed & 387290.4063 & 5162978.5 \\
\hline 248 & Mixed & Mixed & 386779.3125 & 5166321 \\
\hline 249 & Mixed & Mixed & 386676.5625 & 5166279.5 \\
\hline 250 & Mixed & Deciduous & 386857.0625 & 5166785.5 \\
\hline 251 & Open & $X X X X$ & 381578.25 & 5164766 \\
\hline 252 & Open & Open & 383626.3438 & 5166448.5 \\
\hline 253 & Open & Paved & 386888.25 & 5167601.5 \\
\hline 254 & Open & Open & 382244.5 & 5165728.5 \\
\hline 255 & Open & Open & 382338.8125 & 5166673 \\
\hline 256 & Open & Open & 382640.4688 & 5166468.5 \\
\hline 257 & Open & $X X X X$ & 381546.1875 & 5165111 \\
\hline 258 & Open & Open & 383018.25 & 5167601 \\
\hline 259 & Open & $x X X X$ & 381027.75 & 5165143.5 \\
\hline 260 & Open & Open & 384314.9063 & 5166891 \\
\hline 261 & Open & Open & 382838.8125 & 5168850.5 \\
\hline 262 & Open & Open & 382736.75 & 5170852.5 \\
\hline 263 & Open & Open & 381092.2188 & 5165817.5 \\
\hline 264 & Open & Open & 386654.7813 & 5166778 \\
\hline 265 & Open & Open & 383514.8125 & 5166040.5 \\
\hline 266 & Open & Open & 384020.8125 & 5166528.5 \\
\hline 267 & Open & Open & 381272.5938 & 5167450 \\
\hline 268 & Open & Open & 387847.3438 & 5167455 \\
\hline 269 & Open & Open & 386908.2813 & 5166472 \\
\hline
\end{tabular}




\begin{tabular}{|c|c|c|c|c|}
\hline ID Number & Classified As & Field Checked & X-coordinate & Y-coordinate \\
\hline 270 & Open & Open & 382594.25 & 5166087 \\
\hline 271 & Open & Open & 381566.5938 & 5165651 \\
\hline 272 & Open & Open & 387186.8125 & 5166313 \\
\hline 273 & Open & Open & 381502.375 & 5165470 \\
\hline 274 & Open & Open & 382963.7813 & 5168511 \\
\hline 275 & Open & Open & 383368.6563 & 5167491 \\
\hline 276 & Open & Open & 384461.7188 & 5167134 \\
\hline 277 & Open & Jack Pine & 381047.25 & 5167254 \\
\hline 278 & Open & Open & 384010.0938 & 5166342 \\
\hline 279 & Open & Woody Wetlands & 385320.7813 & 5166470 \\
\hline 280 & Open & Jack Pine & 381886.25 & 5167693.5 \\
\hline 281 & Open & Open & 381386.5 & 5167329.5 \\
\hline 282 & Open & Open & 383724.9688 & 5166171 \\
\hline 283 & Open & Open & 382868.4688 & 5170551.5 \\
\hline 284 & Open & Open & 381249.8438 & 5167099 \\
\hline 285 & Open & Open & 385506.5 & 5163464 \\
\hline 286 & Open & Open & 383449.2188 & 5166398.5 \\
\hline 287 & Open & Open & 381709.2813 & 5165400.5 \\
\hline 288 & Open & Open & 382247.125 & 5165757.5 \\
\hline 289 & Open & $x X X X$ & 381274.4688 & 5165030 \\
\hline 290 & Open & $x X X X$ & 381528.4375 & 5164874 \\
\hline 291 & Open & $x X X X$ & 381173.9375 & 5165174 \\
\hline 292 & Open & Open & 383519.875 & 5166534.5 \\
\hline 293 & Open & Open & 382603.6563 & 5166060.5 \\
\hline 294 & Open & Woody Wetlands & 384783.625 & 5165350.5 \\
\hline 295 & Open & Open & 382994.3125 & 5167943.5 \\
\hline 296 & Open & Open & 387429.4688 & 5165000.5 \\
\hline 297 & Open & Open & 382707.9063 & 5165595.5 \\
\hline 298 & Open & Open & 381036.5938 & 5165868 \\
\hline 299 & Open & Paved & 382793.5938 & 5169706.5 \\
\hline 300 & Open & Open & 382119.5938 & 5167201 \\
\hline 301 & Paved & Paved & 387307.7188 & 5165504.5 \\
\hline 302 & Paved & Paved & 385701.4375 & 5167439.5 \\
\hline 303 & Paved & Paved & 384331.625 & 5166838 \\
\hline 304 & Paved & Paved & 386000.5 & 5167458 \\
\hline 305 & Paved & Paved & 386167.4688 & 5167442 \\
\hline 306 & Paved & Paved & 381735.375 & 5166726.5 \\
\hline 307 & Paved & Paved & 385842.8125 & 5167509 \\
\hline 308 & Paved & Paved & 387415.1563 & 5163970 \\
\hline 309 & Paved & Paved & 383960.1875 & 5166594.5 \\
\hline 310 & Paved & Open & 386335.4375 & 5166755 \\
\hline 311 & Paved & Paved & 387157.9688 & 5167588 \\
\hline 312 & Paved & Paved & 386470.4375 & 5166727.5 \\
\hline 313 & Paved & Paved & 387329.9688 & 5163450.5 \\
\hline 314 & Paved & Paved & 387288.4688 & 5167605 \\
\hline 315 & Paved & Paved & 387427.3438 & 5164153 \\
\hline
\end{tabular}




\begin{tabular}{|c|c|c|c|c|}
\hline ID Number & Classified As & Field Checked & X-coordinate & Y-coordinate \\
\hline 316 & Paved & Paved & 386290.375 & 5167480.5 \\
\hline 317 & Paved & Paved & 386649.9063 & 5166737.5 \\
\hline 318 & Paved & Paved & 387214.4375 & 5167586 \\
\hline 319 & Paved & Paved & 386055.125 & 5167471.5 \\
\hline 320 & Paved & Paved & 386992.0938 & 5167617 \\
\hline 321 & Paved & Paved & 386963.1875 & 5167534 \\
\hline 322 & Paved & Paved & 387168 & 5167674.5 \\
\hline 323 & Paved & Paved & 387443.8438 & 5164895 \\
\hline 324 & Paved & Paved & 386238.25 & 5167434 \\
\hline 325 & Paved & Paved & 386654.4375 & 5167197.5 \\
\hline 326 & Paved & Paved & 386538.4063 & 5166711 \\
\hline 327 & Paved & Paved & 385833.4063 & 5167529.5 \\
\hline 328 & Paved & Paved & 387425.25 & 5165124.5 \\
\hline 329 & Paved & Paved & 387198.5625 & 5167645 \\
\hline 330 & Paved & Paved & 387128.375 & 5162705.5 \\
\hline 331 & Paved & Paved & 386289.25 & 5167461.5 \\
\hline 332 & Paved & Paved & 386189.3125 & 5167417.5 \\
\hline 333 & Paved & Paved & 385394.125 & 5167547 \\
\hline 334 & Paved & Paved & 386857.2188 & 5167176.5 \\
\hline 335 & Paved & Paved & 384355.6875 & 5166802.5 \\
\hline 336 & Paved & Paved & 386401.75 & 5167454.5 \\
\hline 337 & Paved & Paved & 385707.4688 & 5167467 \\
\hline 338 & Paved & Paved & 386865.7813 & 5167185.5 \\
\hline 339 & Paved & Paved & 386908.4688 & 5166302.5 \\
\hline 340 & Paved & Paved & 386642.875 & 5166537 \\
\hline 341 & Paved & Paved & 385827.5938 & 5167461 \\
\hline 342 & Paved & Paved & 387278.1563 & 5163258 \\
\hline 343 & Paved & Paved & 387245.3438 & 5167609.5 \\
\hline 344 & Paved & Paved & 385800.8125 & 5167548.5 \\
\hline 345 & Paved & Paved & 386240.3438 & 5167473 \\
\hline 346 & Paved & Paved & 387195.4063 & 5165751.5 \\
\hline 347 & Paved & Paved & 387332.0938 & 5165432.5 \\
\hline 348 & Paved & Paved & 385896.3438 & 5167532 \\
\hline 349 & Paved & Paved & 386869 & 5167180.5 \\
\hline 350 & Paved & Paved & 384445.4375 & 5166541 \\
\hline 351 & Tamarack & Aspen & 382948.125 & 5169119 \\
\hline 352 & Tamarack & Deciduous & 385472.4375 & 5167552 \\
\hline 353 & Tamarack & Aspen & 383198.0625 & 5169610 \\
\hline 354 & Tamarack & Aspen & 385225.0625 & 5167815 \\
\hline 355 & Tamarack & Mixed & 383419.9375 & 5170064 \\
\hline 356 & Tamarack & Aspen & 383900.9063 & 5168557.5 \\
\hline 357 & Tamarack & Tamarack & 387823.4375 & 5165028 \\
\hline 358 & Tamarack & Mixed & 382462.0313 & 5170788.5 \\
\hline 359 & Tamarack & $X X X X$ & 382636.6875 & 5168622.5 \\
\hline 360 & Tamarack & Aspen & 383698.5938 & 5168855 \\
\hline 361 & Tamarack & Mixed & 385373.8438 & 5168267.5 \\
\hline
\end{tabular}




\begin{tabular}{|c|c|c|c|c|}
\hline ID Number & Classified As & Field Checked & X-coordinate & Y-coordinate \\
\hline 362 & Tamarack & Deciduous & 385515.1875 & 5167105.5 \\
\hline 363 & Tamarack & Woody Wetlands & 384286.1563 & 5167842.5 \\
\hline 364 & Tamarack & Deciduous & 385534.75 & 5167103 \\
\hline 365 & Tamarack & Aspen & 383114.8438 & 5169154.5 \\
\hline 366 & Tamarack & Woody Wetlands & 385810.5625 & 5164130 \\
\hline 367 & Tamarack & Tamarack & 387583.25 & 5164980.5 \\
\hline 368 & Tamarack & Aspen & 383210.25 & 5169490.5 \\
\hline 369 & Tamarack & Aspen & 382667.3125 & 5170323 \\
\hline 370 & Tamarack & Mixed & 385253.5 & 5166084 \\
\hline 371 & Tamarack & Aspen & 383348.5625 & 5169408.5 \\
\hline 372 & Tamarack & Tamarack & 387720.7188 & 5165137 \\
\hline 373 & Tamarack & Tamarack & 387603.125 & 5165224 \\
\hline 374 & Tamarack & Tamarack & 387840.5313 & 5165060 \\
\hline 375 & Tamarack & Aspen & 383731.5625 & 5168686.5 \\
\hline 376 & Tamarack & Mixed & 383373.4688 & 5169937 \\
\hline 377 & Tamarack & Mixed & 383393.0938 & 5169685.5 \\
\hline 378 & Tamarack & Aspen & 383156.5313 & 5170334.5 \\
\hline 379 & Tamarack & Tamarack & 387642 & 5164129.5 \\
\hline 380 & Tamarack & Aspen & 385271.3438 & 5167803 \\
\hline 381 & Tamarack & Aspen & 382696.375 & 5170361 \\
\hline 382 & Tamarack & Woody Wetlands & 385707.3438 & 5164199.5 \\
\hline 383 & Tamarack & Aspen & 385296.9063 & 5167891.5 \\
\hline 384 & Tamarack & Tamarack & 387634.75 & 5165254 \\
\hline 385 & Tamarack & Aspen & 382567.0625 & 5170696 \\
\hline 386 & Tamarack & Tamarack & 387608.5 & 5165053.5 \\
\hline 387 & Tamarack & $X X X X$ & 383035.0625 & 5168272 \\
\hline 388 & Tamarack & Aspen & 383042.375 & 5169596.5 \\
\hline 389 & Tamarack & Aspen & 383136.375 & 5169131 \\
\hline 390 & Tamarack & Aspen & 385421.7188 & 5167986 \\
\hline 391 & Tamarack & Tamarack & 387522.125 & 5164041 \\
\hline 392 & Tamarack & Tamarack & 387693 & 5165018 \\
\hline 393 & Tamarack & $X X X X$ & 382649.4688 & 5168633 \\
\hline 394 & Tamarack & Aspen & 383329.9688 & 5169386 \\
\hline 395 & Tamarack & Aspen & 383642.375 & 5168570.5 \\
\hline 396 & Tamarack & Deciduous & 385423.5 & 5166947.5 \\
\hline 397 & Tamarack & Tamarack & 387632.4688 & 5163966 \\
\hline 398 & Tamarack & Mixed & 383578.9375 & 5170792.5 \\
\hline 399 & Tamarack & Aspen & 382847 & 5170005.5 \\
\hline 400 & Tamarack & Woody Wetlands & 385653.5625 & 5165692 \\
\hline 401 & Water & Water & 385162.1875 & 5165995 \\
\hline 402 & Water & Water & 387330.125 & 5166636 \\
\hline 403 & Water & Water & 386971 & 5166698.5 \\
\hline 404 & Water & Water & 387012.0938 & 5166638 \\
\hline 405 & Water & Water & 386405.125 & 5164151 \\
\hline 406 & Water & Conifer & 383722.9063 & 5170078 \\
\hline 407 & Water & Water & 387549.7813 & 5166674.5 \\
\hline
\end{tabular}




\begin{tabular}{|c|c|c|c|c|}
\hline ID Number & Classified As & Field Checked & X-coordinate & Y-coordinate \\
\hline 408 & Water & Water & 387351.1875 & 5166610.5 \\
\hline 409 & Water & Water & 387816.25 & 5164533 \\
\hline 410 & Water & Water & 385102.1875 & 5166896 \\
\hline 411 & Water & Water & 387635.2188 & 5164737.5 \\
\hline 412 & Water & Open & 385936.9063 & 5167334 \\
\hline 413 & Water & Water & 384750.0625 & 5165898 \\
\hline 414 & Water & Water & 387796.5313 & 5164604.5 \\
\hline 415 & Water & Open & 387104.5625 & 5165868 \\
\hline 416 & Water & Conifer & 383695.0313 & 5169966.5 \\
\hline 417 & Water & Water & 386908.0313 & 5164224.5 \\
\hline 418 & Water & Mixed & 385243.8125 & 5166517 \\
\hline 419 & Water & Paved & 387122.4063 & 5167647 \\
\hline 420 & Water & Water & 384777.375 & 5166975.5 \\
\hline 421 & Water & Water & 384528.7188 & 5165673 \\
\hline 422 & Water & Water & 387193.375 & 5166565.5 \\
\hline 423 & Water & Water & 387244.25 & 5164487 \\
\hline 424 & Water & Mixed & 384763.5938 & 5166932.5 \\
\hline 425 & Water & Water & 387770.8438 & 5164639 \\
\hline 426 & Water & Water & 387234.4375 & 5164495.5 \\
\hline 427 & Water & Water & 387242.6563 & 5166609 \\
\hline 428 & Water & Mixed & 386987.1563 & 5166555.5 \\
\hline 429 & Water & Water & 386930.0938 & 5166613 \\
\hline 430 & Water & Water & 386860.125 & 5166629.5 \\
\hline 431 & Water & Open & 387199.3438 & 5165682 \\
\hline 432 & Water & Water & 386860.9063 & 5166698 \\
\hline 433 & Water & Open & 387104.5625 & 5165854 \\
\hline 434 & Water & Water & 385212.7188 & 5166217.5 \\
\hline 435 & Water & Water & 387303.7813 & 5166633.5 \\
\hline 436 & Water & Water & 384935.8125 & 5167075.5 \\
\hline 437 & Water & Water & 387116.2813 & 5166627.5 \\
\hline 438 & Water & Water & 386943.4375 & 5166593.5 \\
\hline 439 & Water & Water & 386902.5938 & 5166689.5 \\
\hline 440 & Water & Water & 387176.375 & 5166634 \\
\hline 441 & Water & Water & 387217.125 & 5166593.5 \\
\hline 442 & Water & Water & 385035.125 & 5166954 \\
\hline 443 & Water & Water & 387071.0625 & 5166574.5 \\
\hline 444 & Water & Water & 387030.2188 & 5164350 \\
\hline 445 & Water & Conifer & 385029.0313 & 5168249 \\
\hline 446 & Water & Deciduous & 385600.8125 & 5167402.5 \\
\hline 447 & Water & Water & 387373.8125 & 5164541 \\
\hline 448 & Water & Water & 385030.25 & 5166953.5 \\
\hline 449 & Water & Open & 386849.2188 & 5166431 \\
\hline 450 & Water & Open & 385424.4063 & 5167343 \\
\hline 451 & Woody Wetlands & Woody Wetlands & 385973.75 & 5165641.5 \\
\hline 452 & Woody Wetlands & Woody Wetlands & 386264.6563 & 5164044.5 \\
\hline 453 & Woody Wetlands & Woody Wetlands & 385115.9375 & 5164679 \\
\hline
\end{tabular}




\begin{tabular}{|c|c|c|c|c|}
\hline ID Number & Classified As & Field Checked & X-coordinate & Y-coordinate \\
\hline 454 & Woody Wetlands & Jack Pine & 382801.125 & 5167832.5 \\
\hline 455 & Woody Wetlands & Mixed & 387674.4688 & 5162563 \\
\hline 456 & Woody Wetlands & Deciduous & 386075.9688 & 5163105 \\
\hline 457 & Woody Wetlands & Deciduous & 386086.5938 & 5163383 \\
\hline 458 & Woody Wetlands & $x X X X$ & 383812.4375 & 5164579 \\
\hline 459 & Woody Wetlands & Mixed & 383381.9688 & 5170634 \\
\hline 460 & Woody Wetlands & Woody Wetlands & 386834.7188 & 5163204 \\
\hline 461 & Woody Wetlands & $X X X X$ & 382802.1563 & 5164854.5 \\
\hline 462 & Woody Wetlands & $x X X X$ & 383893.2813 & 5164605 \\
\hline 463 & Woody Wetlands & Mixed & 387114.4375 & 5166369 \\
\hline 464 & Woody Wetlands & Woody Wetlands & 382376.5 & 5164819.5 \\
\hline 465 & Woody Wetlands & Woody Wetlands & 385420.4063 & 5165828.5 \\
\hline 466 & Woody Wetlands & Deciduous & 385931.375 & 5162365 \\
\hline 467 & Woody Wetlands & Woody Wetlands & 384840.2813 & 5165053.5 \\
\hline 468 & Woody Wetlands & Woody Wetlands & 385658.8438 & 5166022.5 \\
\hline 469 & Woody Wetlands & Woody Wetlands & 385394.6875 & 5165288.5 \\
\hline 470 & Woody Wetlands & Mixed & 387350.1563 & 5162477 \\
\hline 471 & Woody Wetlands & Woody Wetlands & 384620.8125 & 5165887.5 \\
\hline 472 & Woody Wetlands & Deciduous & 385554.5313 & 5163256.5 \\
\hline 473 & Woody Wetlands & $x X X X$ & 383237.8438 & 5164435 \\
\hline 474 & Woody Wetlands & Mixed & 387022.0625 & 5165805 \\
\hline 475 & Woody Wetlands & Woody Wetlands & 384983.9063 & 5165005 \\
\hline 476 & Woody Wetlands & Conifer & 385001.9688 & 5167590 \\
\hline 477 & Woody Wetlands & Jack Pine & 384144.5625 & 5166863 \\
\hline 478 & Woody Wetlands & Deciduous & 386103.125 & 5162791 \\
\hline 479 & Woody Wetlands & Deciduous & 387203.5625 & 5167492.5 \\
\hline 480 & Woody Wetlands & Deciduous & 385910.375 & 5162610 \\
\hline 481 & Woody Wetlands & Woody Wetlands & 387037.75 & 5163163 \\
\hline 482 & Woody Wetlands & $X X X X$ & 383686.9375 & 5165042.5 \\
\hline 483 & Woody Wetlands & Woody Wetlands & 383059.125 & 5170703.5 \\
\hline 484 & Woody Wetlands & Woody Wetlands & 384918.0625 & 5165636.5 \\
\hline 485 & Woody Wetlands & Deciduous & 386147.2813 & 5163028.5 \\
\hline 486 & Woody Wetlands & $x X X X$ & 384522.1563 & 5164374.5 \\
\hline 487 & Woody Wetlands & Deciduous & 387365.8125 & 5167657.5 \\
\hline 488 & Woody Wetlands & Woody Wetlands & 385356.7813 & 5164822 \\
\hline 489 & Woody Wetlands & $X X X X$ & 384561.4375 & 5164399 \\
\hline 490 & Woody Wetlands & Woody Wetlands & 385420.9688 & 5165127 \\
\hline 491 & Woody Wetlands & Deciduous & 385622.2813 & 5163280 \\
\hline 492 & Woody Wetlands & Mixed & 383589.4063 & 5170182.5 \\
\hline 493 & Woody Wetlands & $X X X X$ & 382017.4375 & 5164665 \\
\hline 494 & Woody Wetlands & Woody Wetlands & 385921.6875 & 5165247.5 \\
\hline 495 & Woody Wetlands & Woody Wetlands & 386201.7188 & 5164865.5 \\
\hline 496 & Woody Wetlands & Woody Wetlands & 384887.125 & 5164634.5 \\
\hline 497 & Woody Wetlands & Mixed & 387337.3438 & 5162951.5 \\
\hline 498 & Woody Wetlands & Woody Wetlands & 385700.1875 & 5165946.5 \\
\hline 499 & Woody Wetlands & Woody Wetlands & 385354.6563 & 5165620 \\
\hline
\end{tabular}




\begin{tabular}{ccccc}
\hline ID Number & Classified As & Field Checked & X-coordinate & Y-coordinate \\
\hline 500 & Woody Wetlands & Woody Wetlands & 385139.3125 & 5164616.5 \\
\hline
\end{tabular}




\section{APPENDIX B}

\begin{tabular}{|c|c|c|c|c|}
\hline ID Number & Classified As & Field Checked & X-coordinate & Y-coordinate \\
\hline 1 & Tamarack & Open & 389926.5938 & 5178842.5 \\
\hline 2 & Tamarack & Tamarack & 385800.9688 & 5173663 \\
\hline 3 & Tamarack & Tamarack & 388390.8125 & 5165176.5 \\
\hline 4 & Tamarack & Open & 387521.0313 & 5167993.5 \\
\hline 5 & Tamarack & Tamarack & 385316.6563 & 5173528.5 \\
\hline 6 & Tamarack & Tamarack & 387614.4688 & 5164927 \\
\hline 7 & Tamarack & Open & 391833.7813 & 5178577 \\
\hline 8 & Tamarack & Tamarack & 388467.7188 & 5164979 \\
\hline 9 & Tamarack & Tamarack & 387555.375 & 5165167 \\
\hline 10 & Tamarack & Tamarack & 387772.9688 & 5168114 \\
\hline 11 & Tamarack & Tamarack & 387706.1875 & 5164093.5 \\
\hline 12 & Tamarack & Tamarack & 387634.7813 & 5163869 \\
\hline 13 & Tamarack & Tamarack & 391442.4063 & 5169818 \\
\hline 14 & Tamarack & Tamarack & 391200.0625 & 5170046.5 \\
\hline 15 & Tamarack & Emergent Wetland & 386898.125 & 5160194.5 \\
\hline 16 & Tamarack & Deciduous & 391601.375 & 5169772 \\
\hline 17 & Tamarack & Tamarack & 391385.0313 & 5169871 \\
\hline 18 & Tamarack & Tamarack & 387690.0313 & 5165106 \\
\hline 19 & Tamarack & Tamarack & 387829.4375 & 5168326.5 \\
\hline 20 & Tamarack & Tamarack & 391416.8438 & 5169839.5 \\
\hline 21 & Tamarack & Open & 391819.375 & 5178580 \\
\hline 22 & Tamarack & Open & 390651.6563 & 5176910.5 \\
\hline 23 & Tamarack & Tamarack & 387748.625 & 5163920.5 \\
\hline 24 & Tamarack & Open & 391905.1563 & 5178560 \\
\hline 25 & Tamarack & Tamarack & 388456.1875 & 5165028.5 \\
\hline 26 & Tamarack & Tamarack & 385432.4375 & 5173737 \\
\hline 27 & Tamarack & Woody Wetland & 386878.6563 & 5160113.5 \\
\hline 28 & Tamarack & Tamarack & 387695.0938 & 5165217 \\
\hline 29 & Tamarack & Tamarack & 387890.875 & 5165004.5 \\
\hline 30 & Tamarack & Tamarack & 387667.5 & 5165051.5 \\
\hline 31 & Tamarack & Open & 390971.625 & 5175672 \\
\hline 32 & Tamarack & Tamarack & 387650.125 & 5165119.5 \\
\hline 33 & Tamarack & Open & 390330.4375 & 5175253 \\
\hline 34 & Tamarack & Tamarack & 384197.5938 & 5170266 \\
\hline 35 & Tamarack & Tamarack & 384375.4375 & 5170323 \\
\hline 36 & Tamarack & Open & 392571 & 5178340 \\
\hline 37 & Tamarack & Mixed & 393112.6875 & 5160564 \\
\hline 38 & Tamarack & Tamarack & 387887.1875 & 5168327 \\
\hline 39 & Tamarack & Tamarack & 387699.875 & 5163973.5 \\
\hline 40 & Tamarack & Open & 393887.0938 & 5168793 \\
\hline
\end{tabular}




\begin{tabular}{|c|c|c|c|c|}
\hline ID Number & Classified As & Field Checked & X-coordinate & Y-coordinate \\
\hline 41 & Tamarack & Aspen & 392446.375 & 5175939 \\
\hline 42 & Tamarack & Tamarack & 384004.7813 & 5170510 \\
\hline 43 & Tamarack & Emergent Wetland & 386202.8438 & 5166900.5 \\
\hline 44 & Tamarack & Tamarack & 387763.1875 & 5168127 \\
\hline 45 & Tamarack & Tamarack & 385262.7188 & 5173632.5 \\
\hline 46 & Tamarack & Tamarack & 385263.2188 & 5173585 \\
\hline 47 & Tamarack & Open & 388611.1875 & 5178251.5 \\
\hline 48 & Tamarack & Emergent Wetland & 386954.6563 & 5160209.5 \\
\hline 49 & Tamarack & Tamarack & 387644.4063 & 5163891.5 \\
\hline 50 & Tamarack & Open & 388220.5625 & 5168298.5 \\
\hline 51 & Water & Water & 397149.7813 & 5164544.5 \\
\hline 52 & Water & Water & 395106.5 & 5153309 \\
\hline 53 & Water & Emergent Wetland & 396261.1875 & 5170666.5 \\
\hline 54 & Water & Water & 395683.5938 & 5170849 \\
\hline 55 & Water & Water & 392269.4063 & 5156689 \\
\hline 56 & Water & Water & 393231.9063 & 5156251.5 \\
\hline 57 & Water & Water & 395199.125 & 5153895 \\
\hline 58 & Water & Water & 397083.5313 & 5164922 \\
\hline 59 & Water & Water & 387316.9375 & 5166649 \\
\hline 60 & Water & Water & 395034.8438 & 5153493 \\
\hline 61 & Water & Water & 385967.0938 & 5167923.5 \\
\hline 62 & Water & Emergent Wetland & 391236.625 & 5178051.5 \\
\hline 63 & Water & Water & 392374.2188 & 5153679 \\
\hline 64 & Water & Water & 393477.3125 & 5167647.5 \\
\hline 65 & Water & Water & 397173.0938 & 5164679 \\
\hline 66 & Water & Water & 392357.2188 & 5153786 \\
\hline 67 & Water & Water & 393712.125 & 5167707.5 \\
\hline 68 & Water & Water & 395049.6563 & 5154088.5 \\
\hline 69 & Water & Water & 392149.5938 & 5153803 \\
\hline 70 & Water & Water & 394826.0625 & 5154062.5 \\
\hline 71 & Open & Open & 396652.1563 & 5165724 \\
\hline 72 & Open & Open & 380349.125 & 5167649 \\
\hline 73 & Open & Open & 386125.6875 & 5174011.5 \\
\hline 74 & Open & Open & 386002.8438 & 5173862 \\
\hline 75 & Open & Open & 388464.25 & 5176436 \\
\hline 76 & Open & $X X X X$ & 379762.7813 & 5164978 \\
\hline 77 & Open & Open & 381909.3438 & 5168489 \\
\hline 78 & Open & Open & 390924.3438 & 5175907.5 \\
\hline 79 & Open & Open & 386528.8125 & 5174055 \\
\hline 80 & Open & Open & 388630.5938 & 5178719.5 \\
\hline 81 & Open & Open & 388780.875 & 5176869.5 \\
\hline 82 & Open & Open & 393322.0313 & 5178413 \\
\hline 83 & Open & Open & 391493.25 & 5176576 \\
\hline 84 & Open & Open & 394978.7813 & 5169769.5 \\
\hline 85 & Open & Open & 382182.8438 & 5165938 \\
\hline
\end{tabular}




\begin{tabular}{|c|c|c|c|c|}
\hline ID Number & Classified As & Field Checked & X-coordinate & Y-coordinate \\
\hline 86 & Open & Woody Wetland & 395860.7813 & 5156577 \\
\hline 87 & Open & Open & 383266.5313 & 5166897.5 \\
\hline 88 & Open & Open & 391628.5625 & 5173598 \\
\hline 89 & Open & Open & 381761.2813 & 5165408 \\
\hline 90 & Open & Open & 381758.8438 & 5169321.5 \\
\hline 91 & Deciduous & Deciduous & 394858.4063 & 5164475.5 \\
\hline 92 & Deciduous & Open & 390279.9688 & 5176913 \\
\hline 93 & Deciduous & Woody Wetland & 393305.7188 & 5157699 \\
\hline 94 & Deciduous & Deciduous & 388226.125 & 5161761.5 \\
\hline 95 & Deciduous & Deciduous & 392895.0625 & 5164203 \\
\hline 96 & Deciduous & Deciduous & 389539 & 5167541 \\
\hline 97 & Deciduous & Deciduous & 394621.5 & 5171706 \\
\hline 98 & Deciduous & Deciduous & 388810.4688 & 5162261.5 \\
\hline 99 & Deciduous & Deciduous & 386201.1563 & 5167208.5 \\
\hline 100 & Deciduous & Deciduous & 394537.1875 & 5171722.5 \\
\hline 101 & Deciduous & Open & 392568.7813 & 5178273.5 \\
\hline 102 & Deciduous & Deciduous & 395898.9375 & 5164898.5 \\
\hline 103 & Deciduous & Deciduous & 386079.2813 & 5166228 \\
\hline 104 & Deciduous & Deciduous & 392166.5313 & 5173743 \\
\hline 105 & Deciduous & Deciduous & 392982.2188 & 5165235.5 \\
\hline 106 & Deciduous & Deciduous & 392996.6563 & 5166045 \\
\hline 107 & Deciduous & Woody Wetland & 394318.9063 & 5157362.5 \\
\hline 108 & Deciduous & Deciduous & 388986.8438 & 5172366 \\
\hline 109 & Deciduous & Deciduous & 388121.0625 & 5165152.5 \\
\hline 110 & Deciduous & Deciduous & 394200.25 & 5165450.5 \\
\hline 111 & Conifer & Mixed & 388432.4063 & 5168210 \\
\hline 112 & Conifer & Water & 393168 & 5156564 \\
\hline 113 & Conifer & Woody Wetland & 393825.5 & 5158754.5 \\
\hline 114 & Conifer & Mixed & 397305.7188 & 5163241 \\
\hline 115 & Conifer & Woody Wetland & 397056.9063 & 5152239.5 \\
\hline 116 & Conifer & Mixed & 393064.1875 & 5154346.5 \\
\hline 117 & Conifer & Woody Wetland & 392574.5 & 5154507.5 \\
\hline 118 & Conifer & Woody Wetland & 396538.4688 & 5151636.5 \\
\hline 119 & Conifer & Deciduous & 392349.0938 & 5177682 \\
\hline 120 & Conifer & Woody Wetland & 397908.3438 & 5166877.5 \\
\hline 121 & Conifer & Woody Wetland & 396764.4375 & 5156178.5 \\
\hline 122 & Conifer & Woody Wetland & 391575.4375 & 5163044.5 \\
\hline 123 & Conifer & Woody Wetland & 396384.9688 & 5163926.5 \\
\hline 124 & Conifer & Mixed & 390400.0313 & 5170995 \\
\hline 125 & Conifer & Mixed & 394035.6563 & 5155164 \\
\hline 126 & Conifer & Woody Wetland & 394216.0938 & 5156741.5 \\
\hline 127 & Conifer & Woody Wetland & 390913.0625 & 5171796 \\
\hline 128 & Conifer & Aspen & 382928.2188 & 5170087 \\
\hline 129 & Conifer & Woody Wetland & 391713.7813 & 5161814 \\
\hline 130 & Conifer & Conifer & 380349.6563 & 5169875 \\
\hline 131 & Mixed & Conifer & 385478.4375 & 5172812.5 \\
\hline
\end{tabular}




\begin{tabular}{|c|c|c|c|c|}
\hline ID Number & Classified As & Field Checked & X-coordinate & Y-coordinate \\
\hline 132 & Mixed & Conifer & 390291.4375 & 5174637 \\
\hline 133 & Mixed & Mixed & 386779.125 & 5165941 \\
\hline 134 & Mixed & Mixed & 393683.75 & 5166669.5 \\
\hline 135 & Mixed & Jack Pine & 381995.2813 & 5167794 \\
\hline 136 & Mixed & Woody Wetland & 393019.7813 & 5156764 \\
\hline 137 & Mixed & Woody Wetland & 397753.5 & 5153872.5 \\
\hline 138 & Mixed & Mixed & 391908.9688 & 5163220 \\
\hline 139 & Mixed & Woody Wetland & 388073.75 & 5160603.5 \\
\hline 140 & Mixed & Mixed & 385116.0313 & 5167333.5 \\
\hline 141 & Mixed & Mixed & 387122.4375 & 5166421.5 \\
\hline 142 & Mixed & Woody Wetland & 395702.3438 & 5155918.5 \\
\hline 143 & Mixed & Open & 386906.7813 & 5174636 \\
\hline 144 & Mixed & Mixed & 394359.2188 & 5174998 \\
\hline 145 & Mixed & Mixed & 394719.4688 & 5161182 \\
\hline 146 & Mixed & Mixed & 395290.625 & 5154763.5 \\
\hline 147 & Mixed & Woody Wetland & 391844.7813 & 5161822.5 \\
\hline 148 & Mixed & Woody Wetland & 395294 & 5155104 \\
\hline 149 & Mixed & Mixed & 386187.8438 & 5170350 \\
\hline 150 & Mixed & Conifer & 385845.7813 & 5170640.5 \\
\hline 151 & Aspen & Aspen & 388172.5938 & 5175064.5 \\
\hline 152 & Aspen & Aspen & 388621.3438 & 5174855 \\
\hline 153 & Aspen & Aspen & 389438.0313 & 5176334 \\
\hline 154 & Aspen & Aspen & 382438.0313 & 5171047.5 \\
\hline 155 & Aspen & Aspen & 382256.5625 & 5170543 \\
\hline 156 & Aspen & Aspen & 382222.875 & 5170807 \\
\hline 157 & Aspen & Aspen & 382262.1875 & 5170118 \\
\hline 158 & Aspen & Aspen & 393512.375 & 5165406 \\
\hline 159 & Aspen & Aspen & 381466.0625 & 5170534.5 \\
\hline 160 & Aspen & Aspen & 382566.125 & 5169902.5 \\
\hline 161 & Aspen & Aspen & 382659.9688 & 5168966.5 \\
\hline 162 & Aspen & Aspen & 381119.625 & 5170227 \\
\hline 163 & Aspen & $X X X X$ & 381451.1875 & 5162379.5 \\
\hline 164 & Aspen & Aspen & 391909.9063 & 5173769 \\
\hline 165 & Aspen & Aspen & 392029.6875 & 5177117.5 \\
\hline 166 & Aspen & Aspen & 382220.1563 & 5170502 \\
\hline 167 & Aspen & Aspen & 379098.9688 & 5169505 \\
\hline 168 & Aspen & Aspen & 380930.625 & 5170530.5 \\
\hline 169 & Aspen & Deciduous & 382542.375 & 5169092.5 \\
\hline 170 & Aspen & Aspen & 382417.5313 & 5170863 \\
\hline 171 & Jack Pine & Jack Pine & 381481.2813 & 5166128.5 \\
\hline 172 & Jack Pine & $X X X X$ & 380865.2188 & 5170926 \\
\hline 173 & Jack Pine & Jack Pine & 382042.125 & 5166394 \\
\hline 174 & Jack Pine & $X X X X$ & 380980.8438 & 5165709 \\
\hline 175 & Jack Pine & Woody Wetland & 395091.875 & 5154280.5 \\
\hline 176 & Jack Pine & Jack Pine & 381546.9063 & 5168130 \\
\hline 177 & Jack Pine & Jack Pine & 382848.0625 & 5167003.5 \\
\hline
\end{tabular}




\begin{tabular}{|c|c|c|c|c|}
\hline ID Number & Classified As & Field Checked & X-coordinate & Y-coordinate \\
\hline 178 & Jack Pine & $X X X X$ & 383852.1875 & 5165176 \\
\hline 179 & Jack Pine & Jack Pine & 379633.5 & 5168869.5 \\
\hline 180 & Jack Pine & Jack Pine & 379671.875 & 5167499.5 \\
\hline 181 & Jack Pine & Jack Pine & 379711.7188 & 5167632 \\
\hline 182 & Jack Pine & $x X X X$ & 380784.4375 & 5164866 \\
\hline 183 & Jack Pine & Woody Wetland & 384659.8438 & 5165791 \\
\hline 184 & Jack Pine & Woody Wetland & 381982.1563 & 5165453.5 \\
\hline 185 & Jack Pine & Jack Pine & 381222.5 & 5168034 \\
\hline 186 & Jack Pine & Open & 395117.1875 & 5159686 \\
\hline 187 & Jack Pine & Jack Pine & 379956.5938 & 5168087.5 \\
\hline 188 & Jack Pine & Jack Pine & 382911.0625 & 5167863 \\
\hline 189 & Jack Pine & $x X X X$ & 380362.0625 & 5170836 \\
\hline 190 & Jack Pine & Jack Pine & 381716.4375 & 5166478 \\
\hline 191 & Woody Wetland & Woody Wetland & 397545.3438 & 5155756 \\
\hline 192 & Woody Wetland & Woody Wetland & 394361.0313 & 5162555 \\
\hline 193 & Woody Wetland & Woody Wetland & 397686.125 & 5168504 \\
\hline 194 & Woody Wetland & Woody Wetland & 395639.1563 & 5166222.5 \\
\hline 195 & Woody Wetland & Mixed & 397130.5 & 5168454.5 \\
\hline 196 & Woody Wetland & Mixed & 384692.7813 & 5173856 \\
\hline 197 & Woody Wetland & Deciduous & 397353.25 & 5150968.5 \\
\hline 198 & Woody Wetland & Woody Wetland & 391575.4063 & 5157160 \\
\hline 199 & Woody Wetland & Woody Wetland & 394623.8125 & 5157011.5 \\
\hline 200 & Woody Wetland & Woody Wetland & 390730.7188 & 5160720.5 \\
\hline 201 & Woody Wetland & Woody Wetland & 395606.2188 & 5168127.5 \\
\hline 202 & Woody Wetland & Woody Wetland & 386803.0625 & 5164065.5 \\
\hline 203 & Woody Wetland & Woody Wetland & 384741.9063 & 5170036 \\
\hline 204 & Woody Wetland & Woody Wetland & 397596.125 & 5150349 \\
\hline 205 & Woody Wetland & Woody Wetland & 389359.375 & 5174850.5 \\
\hline 206 & Woody Wetland & Woody Wetland & 389419.375 & 5166532.5 \\
\hline 207 & Woody Wetland & Woody Wetland & 396116.2813 & 5153795 \\
\hline 208 & Woody Wetland & Woody Wetland & 389090.7188 & 5174586.5 \\
\hline 209 & Woody Wetland & Woody Wetland & 396707.0625 & 5155430.5 \\
\hline 210 & Woody Wetland & Mixed & 394903 & 5159436 \\
\hline 211 & Emergent Wetland & Emergent Wetland & 393297.1563 & 5155402 \\
\hline 212 & Emergent Wetland & Emergent Wetland & 394758.4063 & 5163135 \\
\hline 213 & Emergent Wetland & Emergent Wetland & 395766.875 & 5162878 \\
\hline 214 & Emergent Wetland & Emergent Wetland & 394994.9688 & 5168308.5 \\
\hline 215 & Emergent Wetland & Open & 396381.4063 & 5163072.5 \\
\hline 216 & Emergent Wetland & Emergent Wetland & 392421.8438 & 5169870 \\
\hline 217 & Emergent Wetland & Woody Wetland & 393052.8438 & 5155260 \\
\hline 218 & Emergent Wetland & Emergent Wetland & 385311.4688 & 5166394.5 \\
\hline 219 & Emergent Wetland & Emergent Wetland & 395895.5625 & 5162996 \\
\hline 220 & Emergent Wetland & Emergent Wetland & 396195.9375 & 5170530 \\
\hline 221 & Emergent Wetland & Emergent Wetland & 393636.6875 & 5154788.5 \\
\hline 222 & Emergent Wetland & Emergent Wetland & 392100.5625 & 5156133.5 \\
\hline 223 & Emergent Wetland & Emergent Wetland & 393135.7188 & 5155595.5 \\
\hline
\end{tabular}




\begin{tabular}{|c|c|c|c|c|}
\hline ID Number & Classified As & Field Checked & X-coordinate & Y-coordinate \\
\hline 224 & Emergent Wetland & Emergent Wetland & 390491.5625 & 5164680 \\
\hline 225 & Emergent Wetland & Emergent Wetland & 392981.375 & 5166211 \\
\hline 226 & Emergent Wetland & Emergent Wetland & 394896.625 & 5162485 \\
\hline 227 & Emergent Wetland & Emergent Wetland & 395651 & 5157472 \\
\hline 228 & Emergent Wetland & Emergent Wetland & 389630.8125 & 5172189 \\
\hline 229 & Emergent Wetland & Emergent Wetland & 395908.75 & 5163044.5 \\
\hline 230 & Emergent Wetland & Emergent Wetland & 394643.5 & 5159833.5 \\
\hline 231 & Water & Water & 392310.6563 & 5156650.5 \\
\hline 232 & Water & Water & 390284.3125 & 5158903 \\
\hline 233 & Water & Water & 395060.375 & 5153617 \\
\hline 234 & Water & Water & 397149.4688 & 5164899 \\
\hline 235 & Water & Water & 395137.0938 & 5153321 \\
\hline 236 & Water & Water & 392314.8125 & 5153998 \\
\hline 237 & Water & Water & 394721.375 & 5158757.5 \\
\hline 238 & Water & Water & 392404.5625 & 5154947.5 \\
\hline 239 & Water & Water & 392399.6875 & 5153655.5 \\
\hline 240 & Water & Water & 392461.5313 & 5155100.5 \\
\hline 241 & Water & Water & 393460.5625 & 5164454.5 \\
\hline 242 & Water & Water & 392885.6875 & 5156500 \\
\hline 243 & Water & Water & 385945.3438 & 5167835 \\
\hline 244 & Water & Water & 392404.0938 & 5153826.5 \\
\hline 245 & Water & Water & 393613.875 & 5167620 \\
\hline 246 & Water & Water & 392283.2813 & 5157329 \\
\hline 247 & Water & Water & 392370.125 & 5157298.5 \\
\hline 248 & Water & Water & 389353.875 & 5171618 \\
\hline 249 & Water & Water & 395081.3125 & 5153892.5 \\
\hline 250 & Water & Water & 392336.7813 & 5153798.5 \\
\hline 251 & Water & Water & 389311.0938 & 5171555 \\
\hline 252 & Water & Woody Wetland & 395185.0938 & 5158136.5 \\
\hline 253 & Water & Water & 392355.1875 & 5156741.5 \\
\hline 254 & Water & Water & 395202.25 & 5153938 \\
\hline 255 & Water & Water & 393490.2813 & 5167527 \\
\hline 256 & Water & Water & 394895.0313 & 5153879 \\
\hline 257 & Water & Water & 393661.0625 & 5167838.5 \\
\hline 258 & Water & Water & 389328.7813 & 5171637 \\
\hline 259 & Water & Emergent Wetland & 392893.1875 & 5156614 \\
\hline 260 & Water & Water & 395212.0625 & 5153882.5 \\
\hline 261 & Open & Open & 381468.7813 & 5167154 \\
\hline 262 & Open & Open & 380256.6563 & 5167659 \\
\hline 263 & Open & Open & 379265.25 & 5168261.5 \\
\hline 264 & Open & Open & 396302.0625 & 5156935.5 \\
\hline 265 & Open & $x X X X$ & 379653.9688 & 5165260 \\
\hline 266 & Open & Open & 389702.9688 & 5178893 \\
\hline 267 & Open & Open & 385948.2813 & 5167501.5 \\
\hline 268 & Open & Open & 380437.5625 & 5167099 \\
\hline 269 & Open & Open & 378932.4375 & 5167815 \\
\hline
\end{tabular}




\begin{tabular}{|c|c|c|c|c|}
\hline ID Number & Classified As & Field Checked & X-coordinate & Y-coordinate \\
\hline 270 & Open & Open & 388756.6875 & 5179081 \\
\hline 271 & Open & Open & 385716.0938 & 5167461 \\
\hline 272 & Open & Open & 390578.6563 & 5177618.5 \\
\hline 273 & Open & Open & 396235.4688 & 5168558.5 \\
\hline 274 & Open & Open & 392063.0313 & 5174671 \\
\hline 275 & Open & Open & 391933.375 & 5157433 \\
\hline 276 & Open & Open & 379586.8438 & 5166343 \\
\hline 277 & Open & Open & 386793.5938 & 5166505.5 \\
\hline 278 & Open & Open & 382290.5313 & 5165731.5 \\
\hline 279 & Open & Open & 397499.8438 & 5150924.5 \\
\hline 280 & Open & Open & 394965 & 5170020.5 \\
\hline 281 & Open & Open & 390701.6563 & 5175292 \\
\hline 282 & Open & Open & 381368.1563 & 5168644.5 \\
\hline 283 & Open & $X X X X$ & 379722 & 5165613.5 \\
\hline 284 & Open & $x X X X$ & 381518.875 & 5165201.5 \\
\hline 285 & Open & Open & 382253.5 & 5166011.5 \\
\hline 286 & Open & Open & 379908.5938 & 5166797.5 \\
\hline 287 & Open & Open & 382270.6875 & 5168625 \\
\hline 288 & Open & $X X X X$ & 379793.2188 & 5164858.5 \\
\hline 289 & Open & Tamarack & 387666.625 & 5164981 \\
\hline 290 & Open & Open & 383004.7188 & 5165772.5 \\
\hline 291 & Deciduous & Deciduous & 390982.3125 & 5165884 \\
\hline 292 & Deciduous & Deciduous & 391112.2813 & 5160756 \\
\hline 293 & Deciduous & Deciduous & 392105 & 5167409.5 \\
\hline 294 & Deciduous & Mixed & 384824.4688 & 5171225.5 \\
\hline 295 & Deciduous & Deciduous & 396226.3438 & 5172094.5 \\
\hline 296 & Deciduous & Deciduous & 383080.2188 & 5171821 \\
\hline 297 & Deciduous & Deciduous & 395760.5938 & 5163558.5 \\
\hline 298 & Deciduous & Deciduous & 385418.3125 & 5161824.5 \\
\hline 299 & Deciduous & Deciduous & 385589.9063 & 5161236 \\
\hline 300 & Deciduous & Deciduous & 389149.4063 & 5168105 \\
\hline 301 & Deciduous & Deciduous & 394996.6875 & 5157757.5 \\
\hline 302 & Deciduous & Deciduous & 391446.8438 & 5167241.5 \\
\hline 303 & Deciduous & Deciduous & 396934.4688 & 5172735.5 \\
\hline 304 & Deciduous & Open & 390581.125 & 5175167 \\
\hline 305 & Deciduous & Deciduous & 396913.6875 & 5151512 \\
\hline 306 & Deciduous & Deciduous & 386214.8125 & 5163550.5 \\
\hline 307 & Deciduous & Deciduous & 388154.3125 & 5168477.5 \\
\hline 308 & Deciduous & Deciduous & 386260.8125 & 5165470.5 \\
\hline 309 & Deciduous & Deciduous & 395086.0938 & 5167361 \\
\hline 310 & Deciduous & Deciduous & 388420.0938 & 5168979.5 \\
\hline 311 & Deciduous & Deciduous & 394584.875 & 5174227 \\
\hline 312 & Deciduous & Deciduous & 390268 & 5167550 \\
\hline 313 & Deciduous & Deciduous & 391155.7813 & 5164842 \\
\hline 314 & Deciduous & Deciduous & 389732.9688 & 5161642.5 \\
\hline 315 & Deciduous & Deciduous & 388816.375 & 5158829 \\
\hline
\end{tabular}




\begin{tabular}{|c|c|c|c|c|}
\hline ID Number & Classified As & Field Checked & X-coordinate & Y-coordinate \\
\hline 316 & Deciduous & Deciduous & 390046.7813 & 5166545.5 \\
\hline 317 & Deciduous & Deciduous & 386677.8438 & 5162051.5 \\
\hline 318 & Deciduous & Deciduous & 395614.3125 & 5153459 \\
\hline 319 & Deciduous & Deciduous & 385339.0938 & 5173142 \\
\hline 320 & Deciduous & Mixed & 385982.4375 & 5171790 \\
\hline 321 & Conifer & Woody Wetland & 395943.6563 & 5151804 \\
\hline 322 & Conifer & Mixed & 390752 & 5176484 \\
\hline 323 & Conifer & Woody Wetland & 392336.9375 & 5155746.5 \\
\hline 324 & Conifer & Woody Wetland & 385193.0313 & 5164334 \\
\hline 325 & Conifer & Conifer & 385466.4063 & 5159763.5 \\
\hline 326 & Conifer & Woody Wetland & 389854.0313 & 5163596.5 \\
\hline 327 & Conifer & Conifer & 388231.6563 & 5162857.5 \\
\hline 328 & Conifer & Jack Pine & 381652.1875 & 5170335.5 \\
\hline 329 & Conifer & $X X X X$ & 383183.625 & 5162182.5 \\
\hline 330 & Conifer & Deciduous & 387530.9063 & 5166743 \\
\hline 331 & Conifer & Deciduous & 397725.1563 & 5167935.5 \\
\hline 332 & Conifer & Jack Pine & 380775.6875 & 5168160 \\
\hline 333 & Conifer & Conifer & 392981.2813 & 5173517 \\
\hline 334 & Conifer & Conifer & 395883.2813 & 5161328 \\
\hline 335 & Conifer & Woody Wetland & 397317.1563 & 5153557.5 \\
\hline 336 & Conifer & $x X X X$ & 381480.1875 & 5162220.5 \\
\hline 337 & Conifer & Conifer & 384055.4688 & 5168733 \\
\hline 338 & Conifer & $x X X X$ & 381326.7813 & 5164705.5 \\
\hline 339 & Conifer & Open & 386301.7813 & 5167504.5 \\
\hline 340 & Conifer & Woody Wetland & 391963.3125 & 5156557 \\
\hline 341 & Conifer & Conifer & 390343.3125 & 5178552 \\
\hline 342 & Conifer & Woody Wetland & 396515.5313 & 5156182.5 \\
\hline 343 & Conifer & Deciduous & 396934.5313 & 5162967.5 \\
\hline 344 & Conifer & Mixed & 385355.7813 & 5160985 \\
\hline 345 & Conifer & Conifer & 395159.4063 & 5153757 \\
\hline 346 & Conifer & Conifer & 382415.125 & 5171715 \\
\hline 347 & Conifer & Mixed & 397433.5625 & 5168137 \\
\hline 348 & Conifer & Mixed & 392575.6875 & 5159944 \\
\hline 349 & Conifer & Mixed & 392641.5938 & 5174026.5 \\
\hline 350 & Conifer & Conifer & 393351.9375 & 5176323 \\
\hline 351 & Mixed & Mixed & 386691.4688 & 5170165.5 \\
\hline 352 & Mixed & Mixed & 387489.0625 & 5164267.5 \\
\hline 353 & Mixed & Mixed & 395799.625 & 5159060.5 \\
\hline 354 & Mixed & $X X X X$ & 380948.2813 & 5165282.5 \\
\hline 355 & Mixed & Woody Wetland & 393630.9688 & 5161256 \\
\hline 356 & Mixed & Mixed & 395435.5625 & 5155162.5 \\
\hline 357 & Mixed & Woody Wetland & 394312.0938 & 5155547 \\
\hline 358 & Mixed & Mixed & 396026.3438 & 5163258 \\
\hline 359 & Mixed & $X X X X$ & 383836.3438 & 5164019.5 \\
\hline 360 & Mixed & Mixed & 388747.7188 & 5176010 \\
\hline 361 & Mixed & Mixed & 384298.3125 & 5171176 \\
\hline
\end{tabular}




\begin{tabular}{|c|c|c|c|c|}
\hline ID Number & Classified As & Field Checked & X-coordinate & Y-coordinate \\
\hline 362 & Mixed & Woody Wetland & 385448.125 & 5172454.5 \\
\hline 363 & Mixed & Mixed & 396160.3125 & 5155403.5 \\
\hline 364 & Mixed & Deciduous & 395159.625 & 5166509 \\
\hline 365 & Mixed & Mixed & 386172.75 & 5170762.5 \\
\hline 366 & Mixed & Mixed & 396028.4063 & 5160252 \\
\hline 367 & Mixed & Mixed & 391568.4688 & 5157181 \\
\hline 368 & Mixed & $X X X X$ & 381010.2813 & 5165597 \\
\hline 369 & Mixed & Mixed & 395531.7188 & 5156740.5 \\
\hline 370 & Mixed & Mixed & 397073.7188 & 5166064.5 \\
\hline 371 & Mixed & Woody Wetland & 397082.3438 & 5154535 \\
\hline 372 & Mixed & Woody Wetland & 389513.0313 & 5163209 \\
\hline 373 & Mixed & Conifer & 385845.5313 & 5171017 \\
\hline 374 & Mixed & Mixed & 386768.7813 & 5166076.5 \\
\hline 375 & Mixed & Mixed & 386690.9063 & 5170168 \\
\hline 376 & Mixed & Open & 387241.5313 & 5160067 \\
\hline 377 & Mixed & Mixed & 388735.0625 & 5176029.5 \\
\hline 378 & Mixed & Woody Wetland & 389065.5625 & 5159814 \\
\hline 379 & Mixed & Mixed & 391616.3438 & 5169085 \\
\hline 380 & Mixed & Woody Wetland & 394798.9688 & 5157056.5 \\
\hline 381 & Aspen & $X X X X$ & 382649.6563 & 5168653 \\
\hline 382 & Aspen & Aspen & 383138.125 & 5169668 \\
\hline 383 & Aspen & Aspen & 383111.875 & 5169445 \\
\hline 384 & Aspen & Aspen & 382908.875 & 5169937 \\
\hline 385 & Aspen & Aspen & 378986.3125 & 5169244 \\
\hline 386 & Aspen & Aspen & 388385.6875 & 5175146 \\
\hline 387 & Aspen & Aspen & 383020.875 & 5169407 \\
\hline 388 & Aspen & Aspen & 378578.7813 & 5168599 \\
\hline 389 & Aspen & Aspen & 383325.4375 & 5169134 \\
\hline 390 & Aspen & Aspen & 385053.9375 & 5166386.5 \\
\hline 391 & Aspen & Aspen & 378930.1875 & 5169124 \\
\hline 392 & Aspen & $X X X X$ & 382569.8438 & 5163011 \\
\hline 393 & Aspen & Aspen & 382539.6563 & 5169380 \\
\hline 394 & Aspen & Deciduous & 382690.0625 & 5169188.5 \\
\hline 395 & Aspen & Aspen & 383462.4063 & 5169142.5 \\
\hline 396 & Aspen & Open & 382922.125 & 5168671 \\
\hline 397 & Aspen & Aspen & 382404.8125 & 5170148.5 \\
\hline 398 & Aspen & Aspen & 382597.375 & 5169619 \\
\hline 399 & Aspen & Conifer & 383704.625 & 5169929 \\
\hline 400 & Aspen & Deciduous & 382609.9375 & 5169051 \\
\hline 401 & Aspen & Aspen & 383285.1563 & 5169943 \\
\hline 402 & Aspen & Aspen & 392661.5625 & 5176251.5 \\
\hline 403 & Aspen & Woody Wetland & 394755.75 & 5160039.5 \\
\hline 404 & Aspen & Open & 386106.7188 & 5174427 \\
\hline 405 & Aspen & Conifer & 383686.125 & 5169456 \\
\hline 406 & Aspen & Aspen & 392615.7813 & 5176043.5 \\
\hline 407 & Aspen & Aspen & 383106.1563 & 5168664.5 \\
\hline
\end{tabular}




\begin{tabular}{|c|c|c|c|c|}
\hline ID Number & Classified As & Field Checked & X-coordinate & Y-coordinate \\
\hline 408 & Aspen & $X X X X$ & 382176.9375 & 5163389.5 \\
\hline 409 & Aspen & Aspen & 382627.6563 & 5169837 \\
\hline 410 & Aspen & Aspen & 378983.3125 & 5169366.5 \\
\hline 411 & Jack Pine & Jack Pine & 382287.4375 & 5166737.5 \\
\hline 412 & Jack Pine & $X X X X$ & 381302.375 & 5165155.5 \\
\hline 413 & Jack Pine & Jack Pine & 381509.4063 & 5167420 \\
\hline 414 & Jack Pine & Jack Pine & 382169.7813 & 5167874.5 \\
\hline 415 & Jack Pine & $X X X X$ & 381062.7188 & 5165302.5 \\
\hline 416 & Jack Pine & Jack Pine & 383784.3125 & 5166269 \\
\hline 417 & Jack Pine & Jack Pine & 381140.3438 & 5168012 \\
\hline 418 & Jack Pine & Jack Pine & 380882.5625 & 5169076.5 \\
\hline 419 & Jack Pine & $X X X X$ & 381713.3438 & 5163642 \\
\hline 420 & Jack Pine & Jack Pine & 382558.125 & 5168266 \\
\hline 421 & Jack Pine & Jack Pine & 380146.25 & 5168754 \\
\hline 422 & Jack Pine & Jack Pine & 382049.9375 & 5167980.5 \\
\hline 423 & Jack Pine & Jack Pine & 381663.7188 & 5166274 \\
\hline 424 & Jack Pine & Jack Pine & 381055.6563 & 5167665.5 \\
\hline 425 & Jack Pine & Jack Pine & 380101.0625 & 5168489.5 \\
\hline 426 & Jack Pine & Jack Pine & 382036.4375 & 5166730 \\
\hline 427 & Jack Pine & Open & 390877.625 & 5161566 \\
\hline 428 & Jack Pine & Jack Pine & 381840.7813 & 5167942.5 \\
\hline 429 & Jack Pine & Jack Pine & 382461.9375 & 5166335.5 \\
\hline 430 & Jack Pine & $x X X X$ & 384492.7813 & 5161882.5 \\
\hline 431 & Jack Pine & Jack Pine & 379417.9375 & 5168544 \\
\hline 432 & Jack Pine & Jack Pine & 382341.25 & 5166869 \\
\hline 433 & Jack Pine & Jack Pine & 383617.125 & 5167364.5 \\
\hline 434 & Jack Pine & Jack Pine & 381265.75 & 5166535 \\
\hline 435 & Jack Pine & $X X X X$ & 378995.0938 & 5165398.5 \\
\hline 436 & Jack Pine & Jack Pine & 381169.2188 & 5168095 \\
\hline 437 & Jack Pine & Jack Pine & 382931.9063 & 5167726.5 \\
\hline 438 & Jack Pine & Jack Pine & 382725.0625 & 5167084 \\
\hline 439 & Jack Pine & Jack Pine & 379628.5 & 5168556.5 \\
\hline 440 & Jack Pine & Jack Pine & 379915.6875 & 5167991 \\
\hline 441 & Woody Wetland & Conifer & 394622.5 & 5161337.5 \\
\hline 442 & Woody Wetland & $X X X X$ & 381547.1563 & 5161893.5 \\
\hline 443 & Woody Wetland & Woody Wetland & 395886 & 5152527.5 \\
\hline 444 & Woody Wetland & Open & 389791.25 & 5178117 \\
\hline 445 & Woody Wetland & Woody Wetland & 397792.8125 & 5163225 \\
\hline 446 & Woody Wetland & Woody Wetland & 385353.0625 & 5171634.5 \\
\hline 447 & Woody Wetland & Mixed & 394688.3438 & 5172716 \\
\hline 448 & Woody Wetland & Woody Wetland & 397539.9375 & 5166169.5 \\
\hline 449 & Woody Wetland & Woody Wetland & 393938.9688 & 5158597.5 \\
\hline 450 & Woody Wetland & Woody Wetland & 395787.3438 & 5151440 \\
\hline 451 & Woody Wetland & Woody Wetland & 396444.9375 & 5157662 \\
\hline 452 & Woody Wetland & Woody Wetland & 392581.0625 & 5172041 \\
\hline 453 & Woody Wetland & $\mathrm{XXXX}$ & 381644.0625 & 5161468.5 \\
\hline
\end{tabular}




\begin{tabular}{|c|c|c|c|c|}
\hline ID Number & Classified As & Field Checked & X-coordinate & Y-coordinate \\
\hline 454 & Woody Wetland & Woody Wetland & 391845.4063 & 5162307.5 \\
\hline 455 & Woody Wetland & Woody Wetland & 396086.9688 & 5169057.5 \\
\hline 456 & Woody Wetland & Woody Wetland & 397229.75 & 5152115.5 \\
\hline 457 & Woody Wetland & Deciduous & 388653.4688 & 5166877 \\
\hline 458 & Woody Wetland & Woody Wetland & 391571.4688 & 5162084.5 \\
\hline 459 & Woody Wetland & Woody Wetland & 393167.7813 & 5154451.5 \\
\hline 460 & Woody Wetland & Woody Wetland & 397654.2813 & 5156784 \\
\hline 461 & Woody Wetland & Woody Wetland & 389442.5938 & 5163187 \\
\hline 462 & Woody Wetland & Woody Wetland & 394047.5625 & 5159854 \\
\hline 463 & Woody Wetland & Woody Wetland & 393125.625 & 5159071 \\
\hline 464 & Woody Wetland & Woody Wetland & 385581.0625 & 5172378.5 \\
\hline 465 & Woody Wetland & Woody Wetland & 397333.9063 & 5154794 \\
\hline 466 & Woody Wetland & Woody Wetland & 391384.125 & 5160390.5 \\
\hline 467 & Woody Wetland & Woody Wetland & 395926.375 & 5155122 \\
\hline 468 & Woody Wetland & Woody Wetland & 389468.25 & 5160438 \\
\hline 469 & Woody Wetland & Woody Wetland & 396226.25 & 5168214 \\
\hline 470 & Woody Wetland & Woody Wetland & 388388.4063 & 5167926 \\
\hline 471 & Emergent Wetland & Emergent Wetland & 396403.9063 & 5169406 \\
\hline 472 & Emergent Wetland & Emergent Wetland & 394656.3125 & 5163275 \\
\hline 473 & Emergent Wetland & Emergent Wetland & 397261.9063 & 5152664 \\
\hline 474 & Emergent Wetland & Emergent Wetland & 393268.9375 & 5155462 \\
\hline 475 & Emergent Wetland & Emergent Wetland & 395547.2813 & 5168619 \\
\hline 476 & Emergent Wetland & Emergent Wetland & 395097.0313 & 5168374.5 \\
\hline 477 & Emergent Wetland & Emergent Wetland & 393309.375 & 5164774.5 \\
\hline 478 & Emergent Wetland & Woody Wetland & 396003.4375 & 5163215.5 \\
\hline 479 & Emergent Wetland & Emergent Wetland & 396355.6563 & 5162860.5 \\
\hline 480 & Emergent Wetland & $X X X X$ & 380742.3125 & 5163737.5 \\
\hline 481 & Emergent Wetland & Emergent Wetland & 395879.1875 & 5163164.5 \\
\hline 482 & Emergent Wetland & Emergent Wetland & 393674.8125 & 5175372 \\
\hline 483 & Emergent Wetland & Woody Wetland & 396491.2813 & 5162877 \\
\hline 484 & Emergent Wetland & Emergent Wetland & 396917.6875 & 5155392 \\
\hline 485 & Emergent Wetland & Emergent Wetland & 391202 & 5178036 \\
\hline 486 & Emergent Wetland & Emergent Wetland & 395333.1563 & 5157655 \\
\hline 487 & Emergent Wetland & Emergent Wetland & 385895.2813 & 5160534.5 \\
\hline 488 & Emergent Wetland & Emergent Wetland & 394646.625 & 5159780.5 \\
\hline 489 & Emergent Wetland & Emergent Wetland & 392283.2188 & 5162759 \\
\hline 490 & Emergent Wetland & Open & 386978.1563 & 5174562 \\
\hline 491 & Emergent Wetland & Emergent Wetland & 390647.2813 & 5164885 \\
\hline 492 & Emergent Wetland & Emergent Wetland & 393991.5625 & 5158941 \\
\hline 493 & Emergent Wetland & Emergent Wetland & 392762.3438 & 5166379 \\
\hline 494 & Emergent Wetland & Emergent Wetland & 392254.4063 & 5156737 \\
\hline 495 & Emergent Wetland & Emergent Wetland & 393455.75 & 5172361.5 \\
\hline 496 & Emergent Wetland & Woody Wetland & 393010.7188 & 5156584 \\
\hline 497 & Emergent Wetland & Emergent Wetland & 392281.3438 & 5162866.5 \\
\hline 498 & Emergent Wetland & Emergent Wetland & 397213.9688 & 5152633.5 \\
\hline 499 & Emergent Wetland & Emergent Wetland & 395870.5 & 5163151 \\
\hline
\end{tabular}




\begin{tabular}{ccccc}
\hline ID Number & Classified As & Field Checked & X-coordinate & Y-coordinate \\
\hline 500 & Emergent Wetland & Emergent Wetland & 393205.125 & 5155468 \\
\hline
\end{tabular}

